ARGONNE CANCER RESEARCH HOSPITAL 250 EAST FIFTY.NINTH STREET - CHICAGO 37 . HLLINOIS

\title{
Semiannual Report to \\ THE ATOMIC ENERGY COMMISSION
}

MARCH 1954

LEON O. JACOBSON, M, D.

Ediror

OPERATED BY THE UNIVERSITY OF CHICAGO

UNDER

CONTRACT AT-(11-1)-69 


\section{DISCLAIMER}

This report was prepared as an account of work sponsored by an agency of the United States Government. Neither the United States Government nor any agency Thereof, nor any of their employees, makes any warranty, express or implied, or assumes any legal liability or responsibility for the accuracy, completeness, or usefulness of any information, apparatus, product, or process disclosed, or represents that its use would not infringe privately owned rights. Reference herein to any specific commercial product, process, or service by trade name, trademark, manufacturer, or otherwise does not necessarily constitute or imply its endorsement, recommendation, or favoring by the United States Government or any agency thereof. The views and opinions of authors expressed herein do not necessarily state or reflect those of the United States Government or any agency thereof. 


\section{DISCLAIMER}

Portions of this document may be illegible in electronic image products. Images are produced from the best available original document. 


\section{$\underline{I}$}

ACRH-1

ARGONNE CANCER RESEARCH HOSPITAL 95.0 EAST FIFTY-NINTH STREET - CHICAGO 37 . ILLINOIS

\section{No.45069}

Semiannual Report to

THE ATOMIC ENERGY COMMISSION

MARCH 1954

LEON O. JACOBSON, M.D.

Editor

OPERATED BY THE UNIVERSITY OF CHICAGO

UNDER

CONTRACT AT-(11-1)-69 
TABLE OF CONTENTS

Foreword

Staff Publications

Page

. $v$

vi

Preliminary studies on the clinical application of yttrium 90 for intrapleural therapy. G. V. Leroy, R. W. Wissler, and D. W. Talmage.

Observations on the effect of cell suspensions on survival following irradiation. A preliminary report. L. O..Jacobson, E. K. Marks, and E. O. Gaston.

The effect of spleen-shielding on the hematologic values of the blood of rabbits following total-body $\mathrm{X}$ irradiation. L. O. Jacobson, E. K. Marks, and E. O. Gaston.

K. Nakao, L. Plzak, and W. F. Bethard.

Studies on the mechanism of hemolysis in primaquine-sensitive Negroes,
R. J. Dern, I. M. Weinstein, D. W. Talmage, G. V. LeRoy, and A. S. Alving. R. H. Ettinger, and R. B. Capps.

Radioactive sodium chromate for the study of survival of red blood cells.

III. The abnormal hemoglobin syndromes. I. M. Weinstein, C. L. Spurling, H. Klein, and T. F. Necheles.

The effect of growth in a nonirradiated host upon the recovery of irradiated bacteria. E. Beutler, M. J. Robson, and L. O. Jacobson.

Prolongation of the lag phase of irradiated Escherichia coli. E. Beutler, M. J. Robson, and. L. O. Jacobson. 
THIS PAGE

\section{WAS INTENTIONALLY LEFT BLANK}




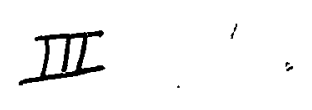

FOREWORD

This publiration reprcients tlie first of the AEC reports from the Argonne Cancer Research Hospital operated by the University of Chicago for the Atomic Energy Commission.

The Argonne Cancer Research Hospital began its clinical and laboratory experimental program in the spring of 1953. Its purpose and program are directed toward the exploitation of high energy radiation sources for the treatment of malignancies; utilization of radioisotopes in the diagnosis and therapy of disease states; and basic research in oncology and hematology; as well as to the elucidation of certain biologic effects of ionizing radiations.

$\therefore \quad$ The physical facilities comprise 58 patient beds available for clinical research, radiochemical laboratories, animal quarters, and three sources of high energy radiations. These latter are a 50-Mev linear electron accelerator, a 2-Mev Van de Graaff accelerator, and an 1800 -curie $\mathrm{Co}^{60}$ unit designed for rotational therapy. The high energy sources are available for biological experimentation as well as physical research, and the therapy of tumors in the human being.

The scientific program of the Argonne Cancer Research Hospital is correlated in general with the broad scientific program of the University of Chicago's Division of the Biological Sciences and the University Clinics of which it is a part. In addition, close liaison is maintained with the scientific program of the Argonne National Laboratory. The operational plan of this research hospital provides for the participation in its facilities and program by the members of the staffs of the Argonne National Laboratory and those universities participating in the Cooperating University Program of the Argonne National Laboratory.

This and subsequent reports will contain, for the most part, summarizations of completed units of study and preliminary reports by a few of the staff members, rather than short progress reports by each. 


\section{II}

\section{STAFF PUBLICATIONS}

Allison, S. K. and S. D. Warshaw. Passage of heavy particles through water. Reviews of Modern Physics, 25: 779 (1953).

Bethard, W. F., M. H. Block and M. Robson. Coexistent chronic lymphatic leukemia and polycythemia vera. Morphologic and clinical studies with particular reference to unusual iron metabolism. Blood, 8: 934 (1953).

Block, M. H., W. F. Bethard and L. O. Jacobson. Secondary hemochromatosis. J. Lab. Clin. Med. 40: 781 (1952). Abstract.

Block, M. H., L. O. Jacobson and W. F. Bethard. Preleukemic acute hurran leukcmia. J. Am. Med. Assoc. 152: 1018 (1953).

Dern, R. J., I. M. Weinstein, D. W. Talmage, G. V. LeRoy and A. S. Alving. The hemolytic effect of primaquine. I. Localization of the drug induced hemolytic defect in primaquine sensitive individuals. J. Lab. Clin. Med. 43: 303 (1954).

Feinstein, A. R., W. F. Bethard and J. D. McCarthy. A New Method, using radioiron, for determining the iron-binding capacity of human serum. J. Lab. Clin. Med. 42: 907 (1953).

Feinstein, A. R., E. L. Gordon and W. F. Bethard. Factors influencing the in vitro. uptake of radiophosphorus by human erythrocytes. J. Lab. Clin. Med. 42: 165 (1953).

Fitch, F. W., P. Barker, K. H. Soules and. R. W. Wissler. A study of antigen localization and degradation and the histologic reaction in the spleen of normal X-irradiated; and spleen-shielded rats. J. Lab. Clin. Med. 42: 598 (1953).

Lanzl; L. H., L. S. Skaggs, J. H. Pingel and J. E. Rose. Transmission of Co ${ }^{60}$ gamma rays through thick uranium. Rev. Sci. Instr.. 24: 394 (1953).

Necheles, T. F., I. M. Weinstein and G. V. LeRoy. Radioactive sodium chromate for the study of survival of red blood cells. I. The effect of Radioactive sodium chromate on red.cells. J. Lab. Clin. Med. 42: 358 (1953).

Weinstein, I. M. and G. V. LeRoy. Radioactive sodium chromate for the study of survival of red blood cells. II. The rate of hemolysis in certain hematologic disorders. J. Lab. Clin. Med. 42: 368 (1953).

Weinstein, I. M., C. L. Spurling and H. Klein. Red cell survival studies in abnormal hemoglobin syndromes. Proc. Central Soc. for Clinical Research, 26 (1953). 


\section{ACRH-1}

PRELIMINARY STUDIES ON THE CLINICAL APPLICATION OF YTTRIUM 90 FOR INTRAPLEURAL THERAPY

By

G. V. LeRoy, R. W. Wissler, and D. W. Talmage

It has been suggested that $\mathrm{Y}^{90}$ might be used for intracavitary therapy, and tests are in progress to determine the validity of this proposal.

The first clinical investigation was carried out with $4.5 \mathrm{ml}$ of $\mathrm{Y}^{90} \mathrm{Cl}_{3}$ containing approximately $4 \mathrm{mg}$ of carrier yttrium that had been obtained from the Abbott Laboratories. * On December 2, 1953, the radioactivity of this solution was assayed to be $0.450 \mathrm{mc}$ per $\mathrm{ml}$. On December 4, a patient in the terminal stage of carcinomatosis was injected intrapleurally with $4.4 \mathrm{ml}$ of the solution. The remaining $0.1 \mathrm{ml}$ was used to prepare two standards: one diluted $1: 10$, and the other, $1: 200$. Forty- $\lambda$ aliquots were used for calibration and the determination of radioactive decay. The data indicate the presence of a contaminant with a longer half-life than that of $\mathrm{Y}^{90}$. They also suggest that this contaminant is a gamma and beta (?) emitter. The 4.4-ml dose administered to the patient was calculated to contain $1350 \mu \mathrm{c}$ of radioactivity, a figure that is in agreement with the assay made by the Abbott Laboratories on the day that the radioisotope was given.

Samples of the serosanguinous fluid were withdrawn from the pleural cavity after the injection of $\mathrm{Y}^{90} \mathrm{Cl}_{3}$ at 3,24 , and $48 \mathrm{hrs}$ and at autopsy on December 11. The radioactivity of the fluid, which was corrected to the time of sampling, decreased exponentially with time and had a half-time of 30 to $36 \mathrm{hrs}$ (Figure 1). The amount of fluid in the cavity remained relatively constant throughout the study.

Only aliquots of urine were obtained for estimation of the rate of excretion of $\mathrm{Y}^{90}$ since the patient was diabetic. The level of radioactivity in the urine was found to be less than $0.05 \mu \mathrm{c}$ per day.

Samples of representative tissues that were taken at autopsy were weighed and then homogenized in a Waring blender. Aliquots were dried at $50^{\circ} \mathrm{C}$ and counted by means of an end-window TCG-2 counter. The results are given inable 1.

It is quite apparent that the isotope leaves the pleural space with a half-time of 30 to $36 \mathrm{hrs}$. About one-half of the radioactivity of the pleural fluid was found at autopsy to be deposited on (or in) the parietal pleura. This finding is evidence that the radioactive particles do not concentrate on the pleura as has been assumed to be the case with colloidal $\mathrm{Au}^{198}$ and colloidal $\mathrm{CrP}^{32} 0_{3}$.

*Dr. D. L. Tabern supplied the radioactive compound, lot no. 610-006. 


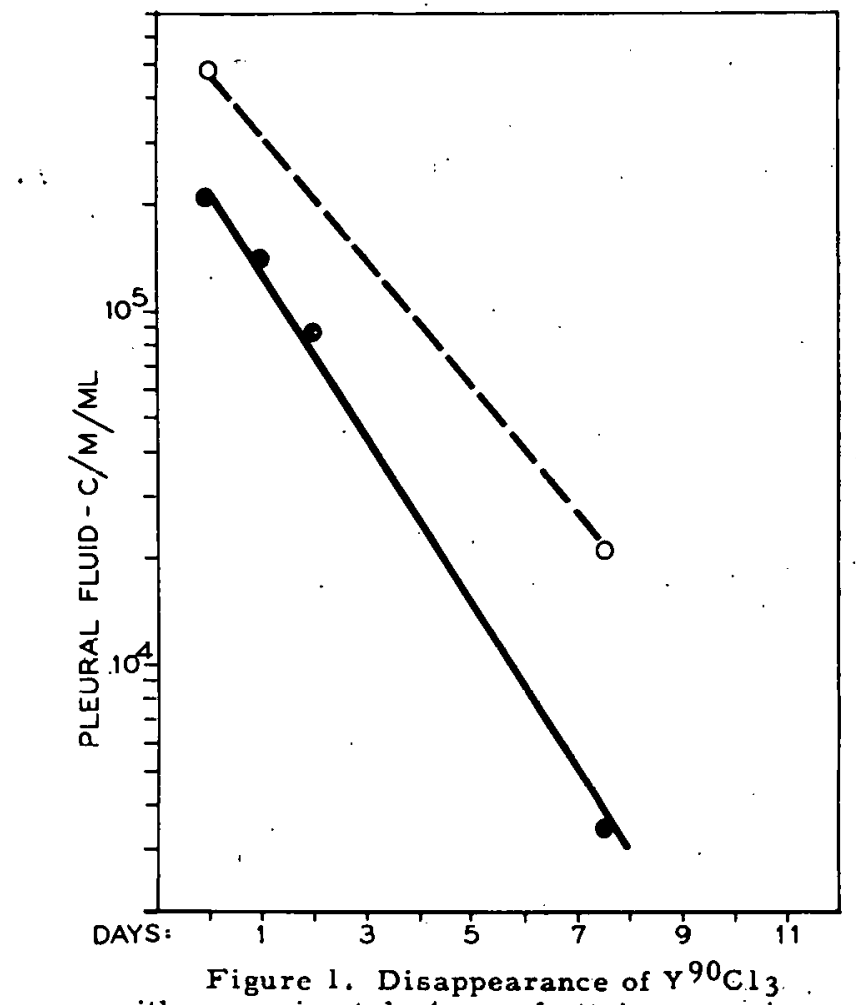

with approximately $4 \mathrm{mg}$ of yttrium carrier. from the pleuralfluid.

- - Half-time for disappearance of dose $(36 \mathrm{hr})$

- Half time for translocation from the pleural cavity $(25-30 \mathrm{hr})$.

\section{Table 1}

The distribution of $\mathrm{Y}^{90}$ in the body of a patient weighing $78 \mathrm{~kg}, 8$ days after the intrapleural administration of $1350 \mu \mathrm{C}$ of $\mathrm{Y}^{90} \mathrm{Cl}_{3}$.

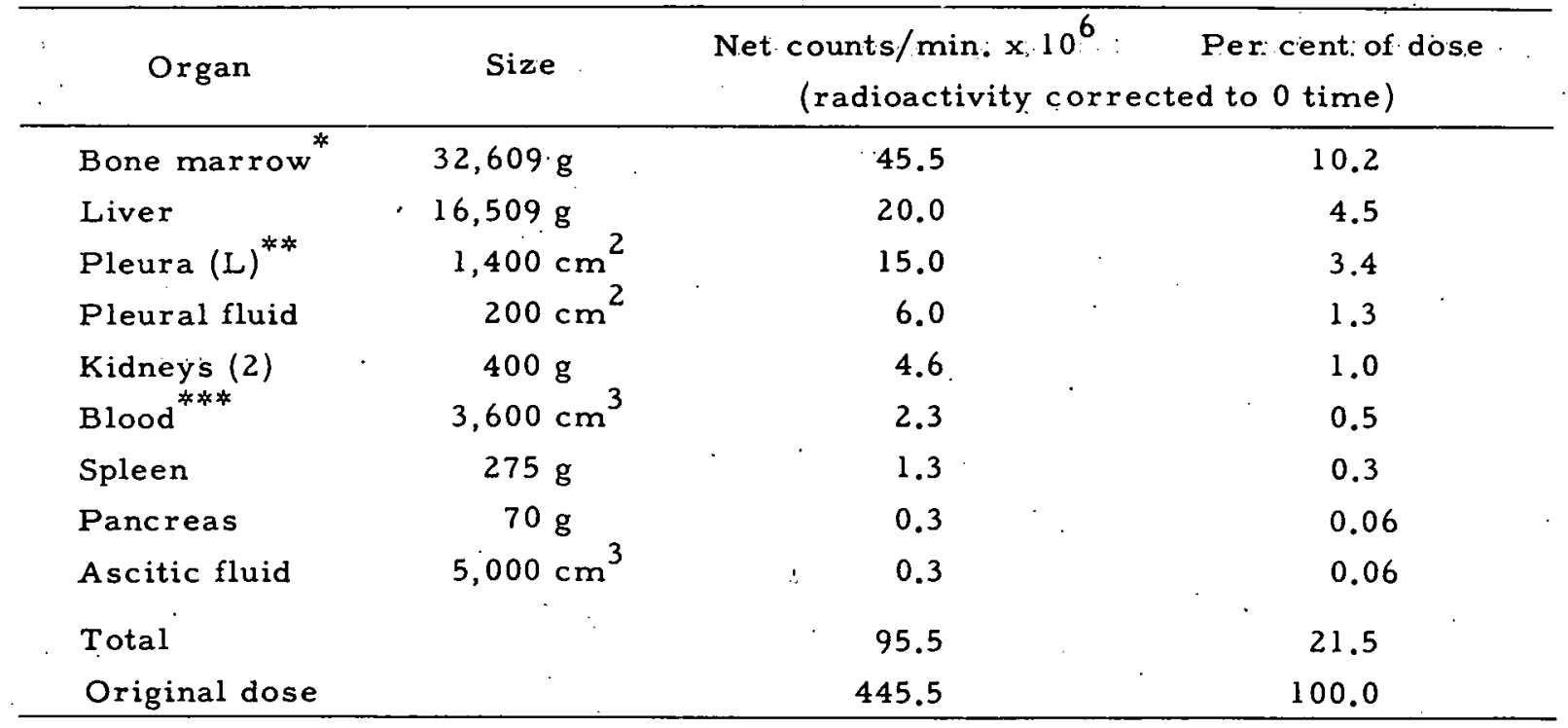

* Based upon the AEC "Standard Man" value for combined red and white bone marrow. * * Pleura was assumed to be a cylinder, $15 \times 30 \mathrm{~cm}$.

* Blood volume was taken as $2 / 3$ of normal. The normal value for a subject of this size is 7 per cent of body weight. 
The bone marrow (and bone?), liver, and kidney appear to be the chief sites of deposition (Table 2). The fraction of the dose that reaches the bone is very likely exccssive in lerms of the possible effects of a potent beta emitter on such radiosensitive tissue as bone marrow. We suspect that the doses of $\mathrm{Y}^{90} \mathrm{Cl}_{3}$ that are found to be effective against pleural metastases will be beyond the limits of safety for bone marrow.

Table 2

Radioactivity in various tissues 8 days after administration of $\mathrm{Y}^{90}$.

\begin{tabular}{lc}
\multicolumn{1}{c}{ Tissue } & $\begin{array}{c}\text { Radioactivity } \\
\text { (counts per min. per g) }\end{array}$ \\
\hline Bone (marrow?) & 13,900 \\
Liver & 12,170 \\
Kidney & 11,812 \\
Spleen & 4,790 \\
Pancreas & 5,400 \\
Thyroid & 5,400 \\
Heart & 2,900 \\
Carcass & $5,000 *$ \\
\hline
\end{tabular}

* Estimated by difference, using data from the AEC "Standard Man."

In our second clinical study, $\mathrm{Y}^{90} \mathrm{Cl}_{3}$ with $400 \mathrm{mg}$ of carrier was injected into a 65-year-old patient who had carcinoma of the lung with pleural effusion. The patient was given only $100 \mu \mathrm{c}$ because she was not considered to be preterminal.

Samples of pleural fluid were withdrawn at $4 \mathrm{hrs}$ and at 1, 2, 5, and 7 days after injection. Five-ml aliquots were centrifuged, and $1 \mathrm{ml}$ of supernatant was taken and measured for radioactivity. The sediments were resuspended in $1.0 \mathrm{ml}$ of physiologic saline, placed in planchets, and measured. The results are given in Table 3 and ${ }^{\prime} F i g u r e$ 2. The half-time for translocation was found to be about 6 days.

Table 3

Radioactivity in the pleural effusion from a preterminal patient treated with $\mathrm{Y}^{90} \mathrm{Cl}_{3}$ with carrier added.

\begin{tabular}{rrr}
\hline Time & $\begin{array}{c}\text { Supernatant } \\
\text { counts/minutes/5 ml Sediment }\end{array}$ \\
\hline 4 hrs & 29,475 & 1,219 \\
24 hrs & 27,500 & 1,385 \\
48 hrs & 24,980 & 2,567 \\
5 days & 18,000 & - \\
7 days & 15,000 & - \\
\hline
\end{tabular}

Theoretically, the amount of $\mathrm{Y}^{90} \mathrm{Cl}_{3}$ that should be given therapeutically would be 7 to $10 \mathrm{mc}$ if the amount of $\mathrm{CrP}^{32} 0_{3}$ that is given under similar circumstances is the 


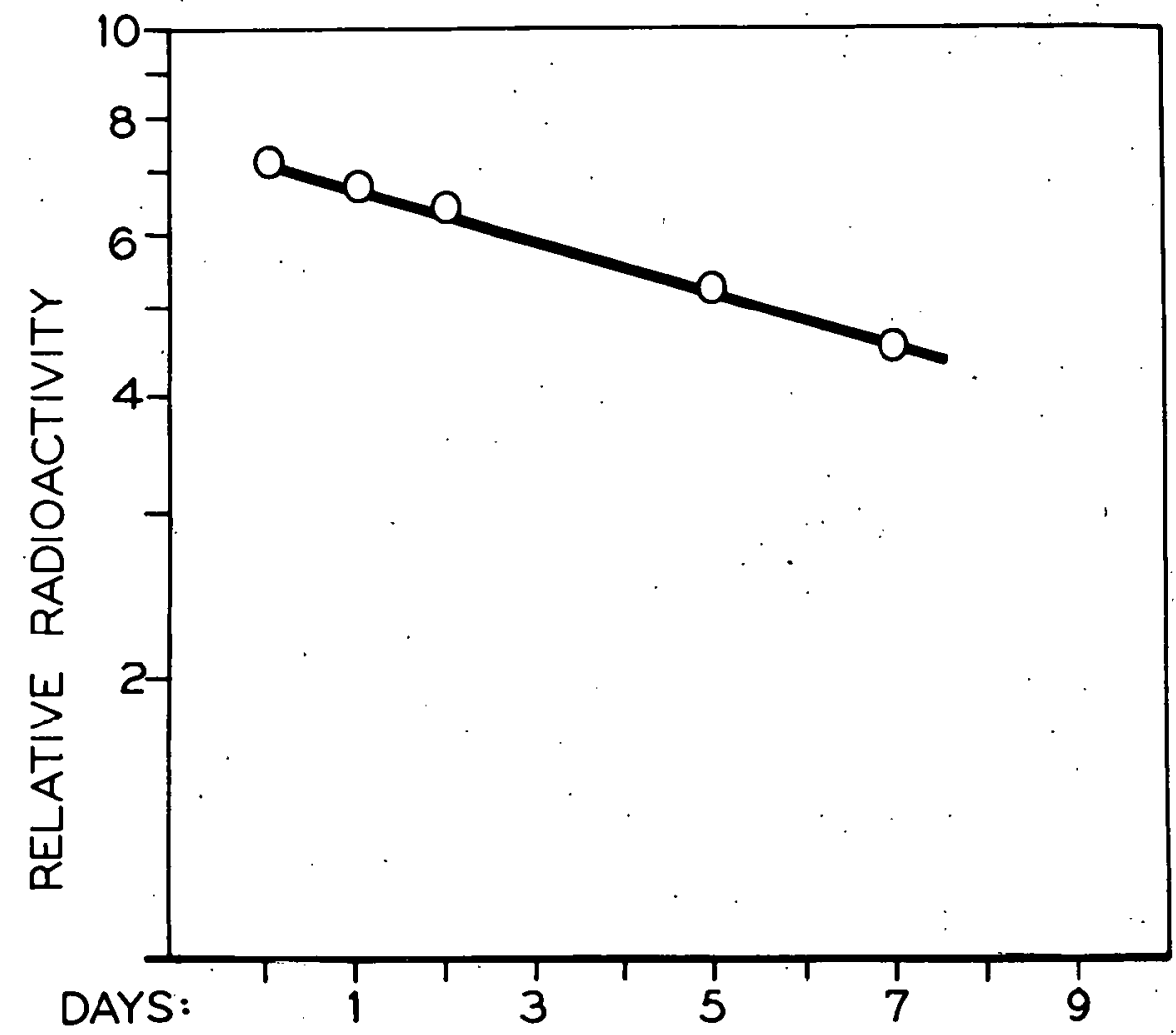

Figure 2. Disappearance of $\mathrm{Y}^{90} \mathrm{Cl} 3$ with $400 \mathrm{mg}$ carrier from the pleural fluid.

basis for the determination. However, with such a large dose, $1.5 \mathrm{mc}$ would be present in the bone marrow at the end of the first half-time. The amount of radiation is much greater than would be expected from the data from studies on $\mathrm{CrP}^{32} \mathrm{O}_{3}$ and is probably too great for the class of patient that would be given this treatment. The radiation dose (number of equivalent roentgens from $l \mu \mathrm{c}$ per $\mathrm{g}$ of tissue) delivered by $\mathrm{Y}^{90}$ is about $1 / 4$ that by $P^{32}$. The actual dose that might be given is predicted to be 4 times the dose of $\mathrm{P}^{32}$.

Our finding that the amount of carrier than will alter absorption is related to the volume of the effusion is in agreement with that of Laszlo(1). The difficulties involved in planning therapy under these conditions are obvious since the quantities of yttrium leaving the effusion are so large and unpredictable.

It is our recommendation that colloidal preparations of $\mathrm{Y}^{90}$ be made available for clinical tests.

\section{LITERATURE CITED}

1. Laszlo D., Unpublished memorandum supplied by Dr. D. L. Tabern. 


\title{
OBSERVATIONS ON THE EFFECT OF CELL SUSPENSIONS ON SURVIVAL FOLLOWING IRRADIATION: $\Lambda$ PRELIMINARY REPORT By
}

\author{
L. O. Jacobson, E. K. Marks, and E. O. Gaston
}

Our finding that spleen-shielding and spleen or embryo transplants enhance the survival of mice exposed to a lethal dose of total-body $X$ radiation (1025 r) led to some further experiments in which we demonstrated that a suspension of spleen cells injected intraperitoneally also increases the survival of mice exposed to $800 \mathrm{r}^{(1,2)}$. This latter observation was confirmed by Cole et al. ${ }^{(3)}$ Lorenz ${ }^{(4)}$ found that the survival of mice exposed to $900 \mathrm{r}$ was significantly increased if the animals were given intravenous injections of bone marrow suspensions after $X$ irradiation. These findings together with the observation that liver-shielding or the injection of mashed embryo suspensions was protective against radiation-induced mortality prompted us to investigate the effectiveness of suspensions of cells from the liver of adult, baby, and embryonic mice. In addition, since the results from some of the experiments varied because the suspensions of cells from the several sources (i.e., spleen, bone marrow, and liver) were not standardized, it seemed timely to determine the optimum number of cells from each of these tissues that was necessary to provide maximum survival following irradiation. Such information was needed to compare the "potential" of cells from various tissues and to serve as a baseline for "cell-type" studies of the various suspensions.

This report gives the observations that we have made thus far.

\section{MATERIAL AND METHODS}

Bone marrow: Lórenz ${ }^{(4)}$ aspirated bone marrow from 4 long bones (femora and radii) by means of a 26 -gauge hypodermic needle. The marrow was then suspended in buffered saline and given immediately after preparation to an irradiated mouse. We employed this technique in our earlier studies. The amount of marrow obtained under these conditions was found to vary considerably and thus the results might not be reproducible.

Mice that were to receive bone marrow suspensions were exposed to $900 \mathrm{r}$ totalbody $\mathrm{X}$ radiation. Bone marrow for the suspensions was obtained from 9- to 12-weekold mice. Saline or Locke's solution was used as the diluent. Cell counts were made according to routine laboratory methods to determine the number of nucleated cells per cu. $\mathrm{mm}$. In preliminary experiments, the suspensions taken from individual mice 
varied from a maximum of $10 \times 10^{6}$ cells $^{*}$ in $0.5 \mathrm{cc}$. of diluent to a minimum of $0.07 \mathrm{x}$ $10^{6}$ cells in $0.5 \mathrm{cc}$. diluent. Pooled marrow aspirations were therefore made and the suspension was standardized so that $0.5 \mathrm{cc}$. contained the number of cells we wished to administer intravenously to each irradiated mouse. Suspensions varying from $37.5 \times$ $10^{6}$ to $0.13 \times 10^{6}$ cells were injected intravenously into the irradiated mice.

Although survival was found to be enhanced with as few as $0.5 \times 10^{6}$ cells per mouse, a suspension that provided each mouse with 8 to $10 \times 10^{6}$ cells proved to be the most effective (64 per cent survived) in decreasing mortality (Figure 1). With a suspension of 6 to $8.0 \times 10^{6}$ cells per mouse, 50 per cent of the animals survived the 28-day period of observation. With a decreasing number of cells, the per cent survival decreased correspondingly; only 9 per cent survived when less than $0.5 \times 10^{6}$ cells were given to each mouse. It is interesting that no deaths occurred after the 13th day in 2 of the groups (Figure 1). These groups consisted of 46 and 38 mice, respectively, and each mouse was injected with 3 to 6 and 0.5 to $1.0 \times 10^{6}$ cells. It must be emphasized that suspensions containing more than $10 \times 10^{6}$ cells in $0.5 \mathrm{cc}$. were no more effective in enhancing survival than were these containing 3 to $6 \times 10^{6}$ cells. Of 171 mice that received more than $10 \times 10^{6}$ cells, only 44 per cent survived the 28 -day period of observation. The incapacity of these concentrations to provide the protection afforded by lesser.amounts is being studied.

A preliminary experiment with bone marrow cells in which the donor mice were 5 to 6 weeks old has been completed. Indiçations are that marrow from these mice is more effective than that from mature mice, e.g., 20 of 25 animals survived (80 per cent) when 7 or $8 \times 10^{6}$ cells were injected intravenously after $900 \mathrm{r}$.

To determine the length of time during which radiation damage could be reversed, bone marrow suspensions were injected intravenously into irradiated mice from 1 to 5 days after $900 \mathrm{r} \mathrm{X}$ radiation. Some beneficial effect was. still obtained when the bone marrow was injected as late as 5 days after $X$ irradiation.

Effect of spleen-cell injections on survival of irradiated mice: Studies of the effect of spleen cells on the survival of irradiated mice were also carried out in a way that was similar to those described for the bone marrow suspensions. In preliminary experiments, the spleen cells were obtained by inflating the extirpated mouse spleen with saline or Locke's solution. The cells that were thus extruded were injected intravenously into. mice that had been subjected to $900 \mathrm{r} X$ radiation.

In subsequent experiments, the spleens from adult mice were mashed gently in a mortar, or cut and pushed through a syringe, and suspended in Locke's solution. All of the cells that could be removed conveniently with a 26 -gauge needle were used to make the suspension. In some instances, the cells were centrifuged and washed several times with Locke's solution before the final suspension was made. Since the spleens

* This refers throughout the paper to nucleated cells. It does not include red blood cells except those nucleated ones found in an acetic acid ( $2 \%)$ dilution. 


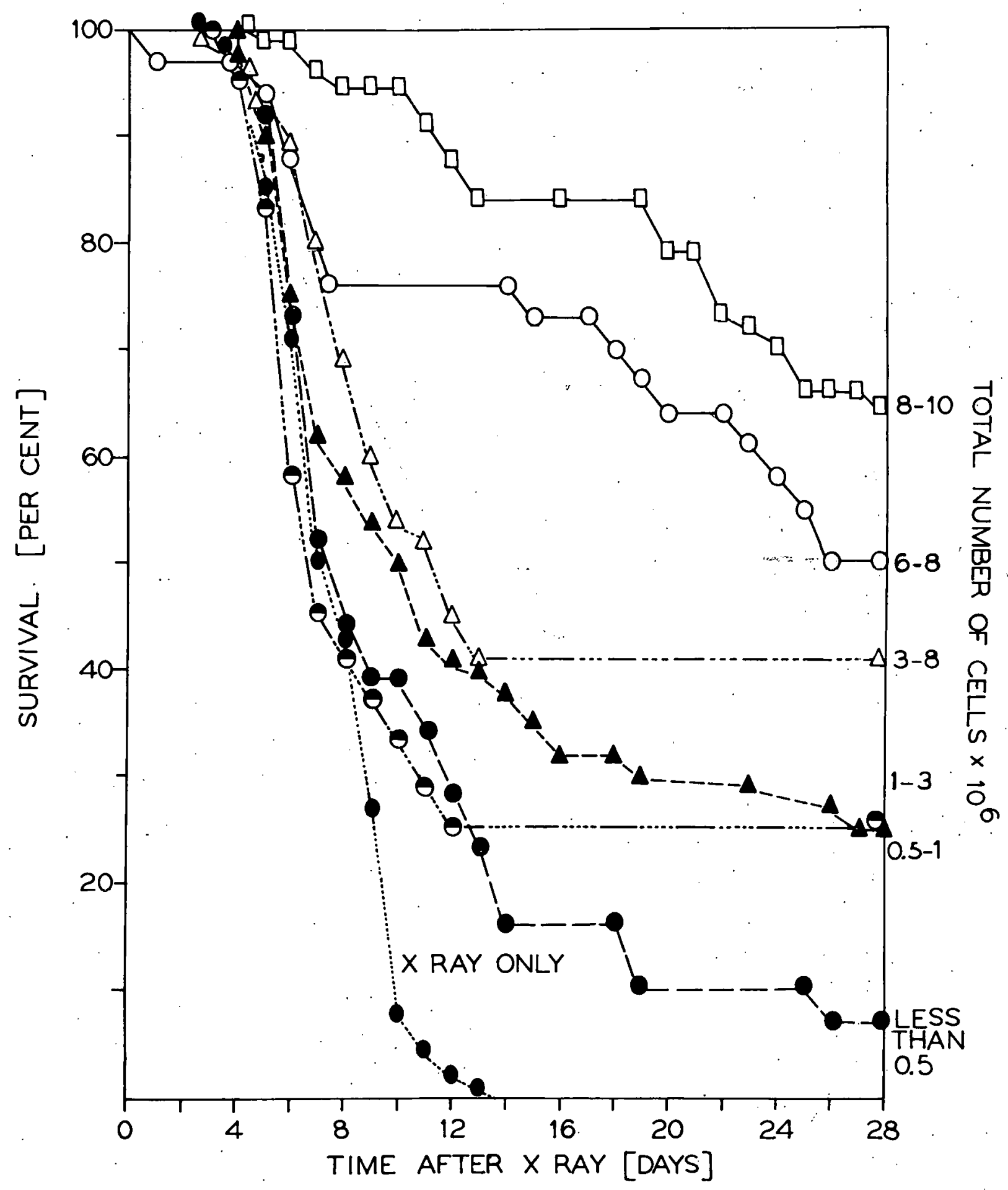

Figure 1. A comparison of the effect of intravenous injections of various concentrations of bone marrow cell suspensions on the survival of mice exposed to $900 \mathrm{r}$.

$-7-$ 
from baby mice are very fragile, it is necessary only to push them through a syringe to release the cells desired for injection, and centrifugation is not necessary.

In the original work by Jacobson et al. $^{(5)}$ in which splenic implants were found to enhance survival, 4 spleens from baby mice were necessary to effect increased survival of adult irradiated mice. When spleen-cell suspensions are injected intravenously, however, the cells from only one spleen were sufficient to enhance survival in several irradiated mice: To correlate the results of these studies with those from bone marrow experiments, cell counts were made on the spleen-cell suspensions.

From the available data it appears that 2 to $3 \times 10^{6}$ cells obtained from the spleens of 2-day mice produce a beneficial effect on the survival of irradiated mice. Forty-one per cent of the mice exposed to $900 \mathrm{r}$ survived (Figure 2). With 8 to $10 \mathrm{x}$ $10^{6}$ cells from the spleens of 2 -day mice, 70 per cent of the recipients survived the 28 day period of observation, with no deaths occurring before the 18 th day after irradiation. Five of 9 mice injected with only $0.6 \times 10^{6}$ cells survived $900 \mathrm{r}$. Experiments in which $0.6 \times 10^{6}$ and fewer spleen cells were injected are in progress. With 20 mice, 12 ( 60 per cent) survived lethal cxposures when 8 to $10 \times 10^{6}$ cells were given 1 day after exposure to $900 \mathrm{r}$. This is similar to the data from the bone marrow studies.

Cells obtained from adult spleens have thus far proved to be less effective than cells from the spleens of younger mice, and in preliminary experiments, instantaneous death resulted after the intravenous administration of cell suspensions containing $10 x$ $10^{6}$ or more cells.* However, the toxic action can be overcome to a great extent, if the adult spleen cells are washed thoroughly by centrifugation in Locke's solution and if a few drops of heparin are added to the suspension made from the centrifuged cells. The preliminary data (Table 1) suggest that the effectiveness of spleen cells decreases by a factor of 4 from mice aged 2 days to 6 weeks and by a factor of 5 from those aged 6 weeks to adulthood ( 10 weeks).

Table 1

Effect of age of donor mouse on effectiveness of spleen-cell suspension.

\begin{tabular}{l|c|c}
\hline $\begin{array}{c}\text { Mouse spleen } \\
\text { (age) }\end{array}$ & $\begin{array}{c}\text { Total no. of } \\
\text { cells injected } \\
\left(\times 10^{6}\right)\end{array}$ & $\begin{array}{c}\text { Survival of } \\
\text { irradiated } \\
\text { recipient } \\
(\%)\end{array}$ \\
\hline 2 days & $2-3$ & 42 \\
6 weeks & $8-10$ & 46 \\
10 to 12 weeks (adult) & $40-50$ & 43 \\
\hline
\end{tabular}

Although spleen cells from adults had little, if any, effect on the survival of mice when $8 \times 10^{6}$ cells were given, 43 per cent of the irradiated recipients survived when 40 to $50 \times 10^{6}$ cells were injected intravenously.

* Considerable difficulty is encountered when heparin is added to the suspension before the cells are counted since clumping of the white cells under these conditions is marked and accurate counts cannot be made. 


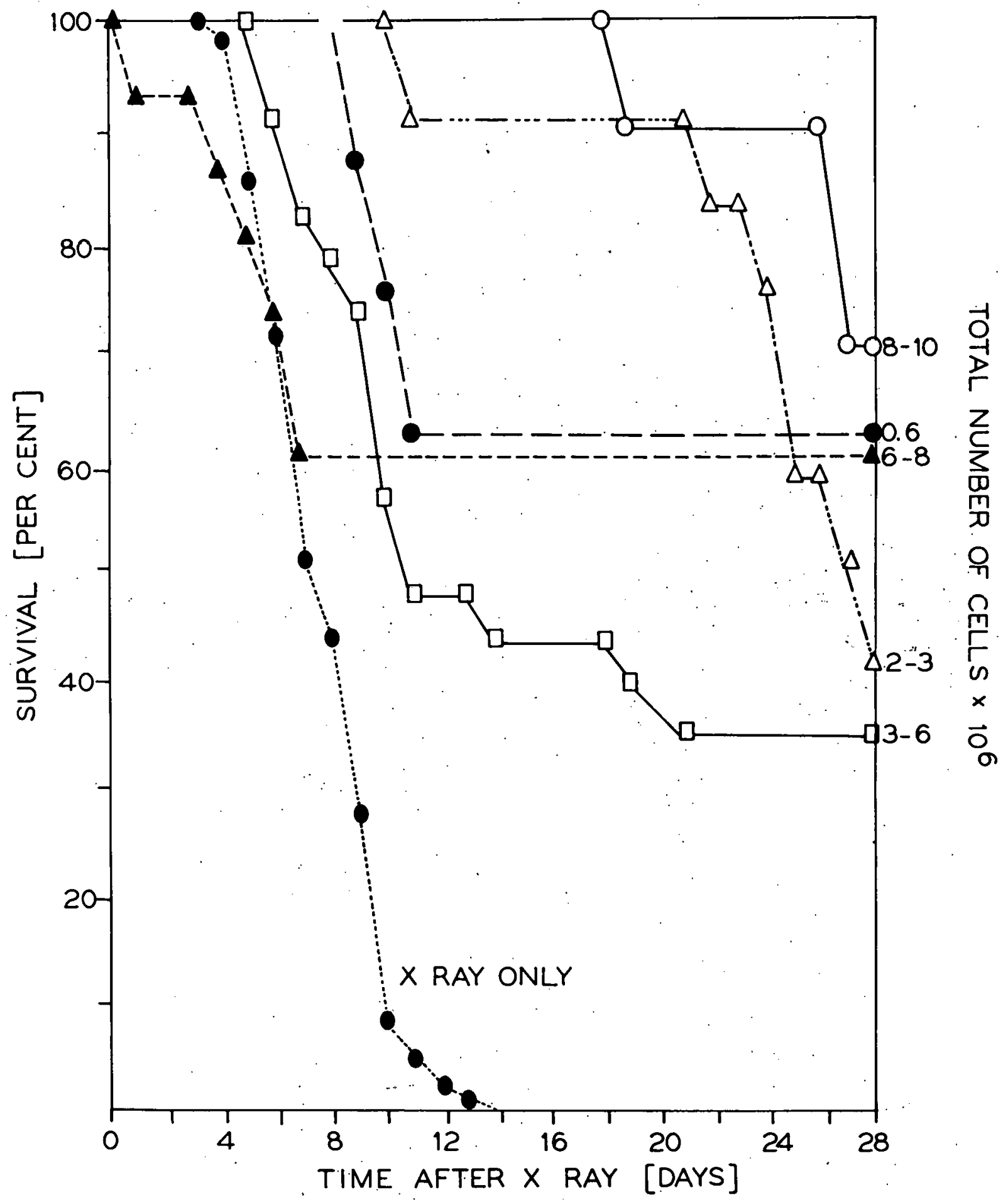

Figure 2. A comparison of the effect of intravenous injections of various concentrations of spleen cell suspensions on the survival of mice exposed to $900 \mathrm{r}$.

$-9-$ 
The effect of embryo cells on survival of mice: Since earlier studies have shown that 35 per cent of the mice survive when embryo mash is given intraperitoneally following a lethal exposure to $X$ radiation (1025 r) and since only $2 \times 10^{6}$ cells from 2 -day mouse spleens are necessary to enhance survival, an effort was made to determine the number of embryo cells that are necessary to bring about this protective action.

Intravenously-injected suspensions that were made from cells obtained by pressing the entire embryo through a tissue press or by grinding it in a mortar inevitably proved fatal to the irradiated recipient. Portions of the soft tissue of the embryo (mostly liver) were tested. Suspensions from this tissue were made with Locke's solution and were given intravenously after irradiation. It was found that only 1 to $3 \times 10^{6}$ cells are necessary to increase survival ( 50 per cent).

With 12 to $88 \times 10^{6}$ cells, 78 per cent of the mice survived $900 \mathrm{r}$. Fifty per cent survived with as few as 1 to $3 \times 10^{6}$ cells, and 24 per cent survived with 0.3 to $1.0 \times$ $10^{6}$ cells. Preliminary studies show that such a small amount as $0.190 \times 10^{6}(190,000)$ embryo (liver) cells will produce a beneficial effect (4 of 10 survived, Figure 3 ).

The comparative effectiveness of various tissue cell suspensions is shown in Figure 4. The data give the results when 6.0 to $8.0 \times 10^{6}$ cells were injected per mouse after it had been exposed to $900 \mathrm{r}$. This is probably not, however, a true comparison since the bone marrow represents the effect of adult (10-to 12-week) tissue, whereas the liver was obtained from embryos and spleen tissue was obtained from 2-day mice.

The effect of liver cells on the survival of irradiated mice: In previous experiments it was found that cells obtained from embryonic mouse liver effectively enhanced the survival of mice exposed to $900 \mathrm{r}$. Therefore, studies were made of cells from the liver of 2-day-old mice to determine whether such cells are equally effective when the liver is no longer an embryonic organ.

The mice were killed by cervical fracture, and the liver was removed and mashed by pushing it several times through a syringe, using Locke:s solution as the diluent. The cells were removed with a 26 -gange needle, and cell counts were made. The suspension was then injected intravenously into the irradiated mice.

In a preliminary experiment, the cells were obtained from 2-day-old CF No. 1 mice and.were given intravenously to $\mathrm{LAF}_{1}$ females exposed previously to $900 \mathrm{r}$. No deaths occurred during the first 21 days after irradiation; however, 3 of 8 died before the 28-day period of observation was completed. In subsequent experiments, the CF No. 1 mice were used as both recipients and donors. Of the 49 mice that have been injected with cells from the liver of 2-day-old mice, 22 have survived the 28-day period of observation: Since the number of animals used in these studies is small (Table 2), it is difficult to evaluate the results on a cell-count basis: 3 of 8 mice survived with 1.6 $\times 10^{6}$ cells as well as with $5.1 \times 10^{6}$ cells. These experiments are being repeated to determine the number of cells that will produce the maximum effectiveness. A preparation of the 2-day liver cells used for injection is shown in Figure 5. 


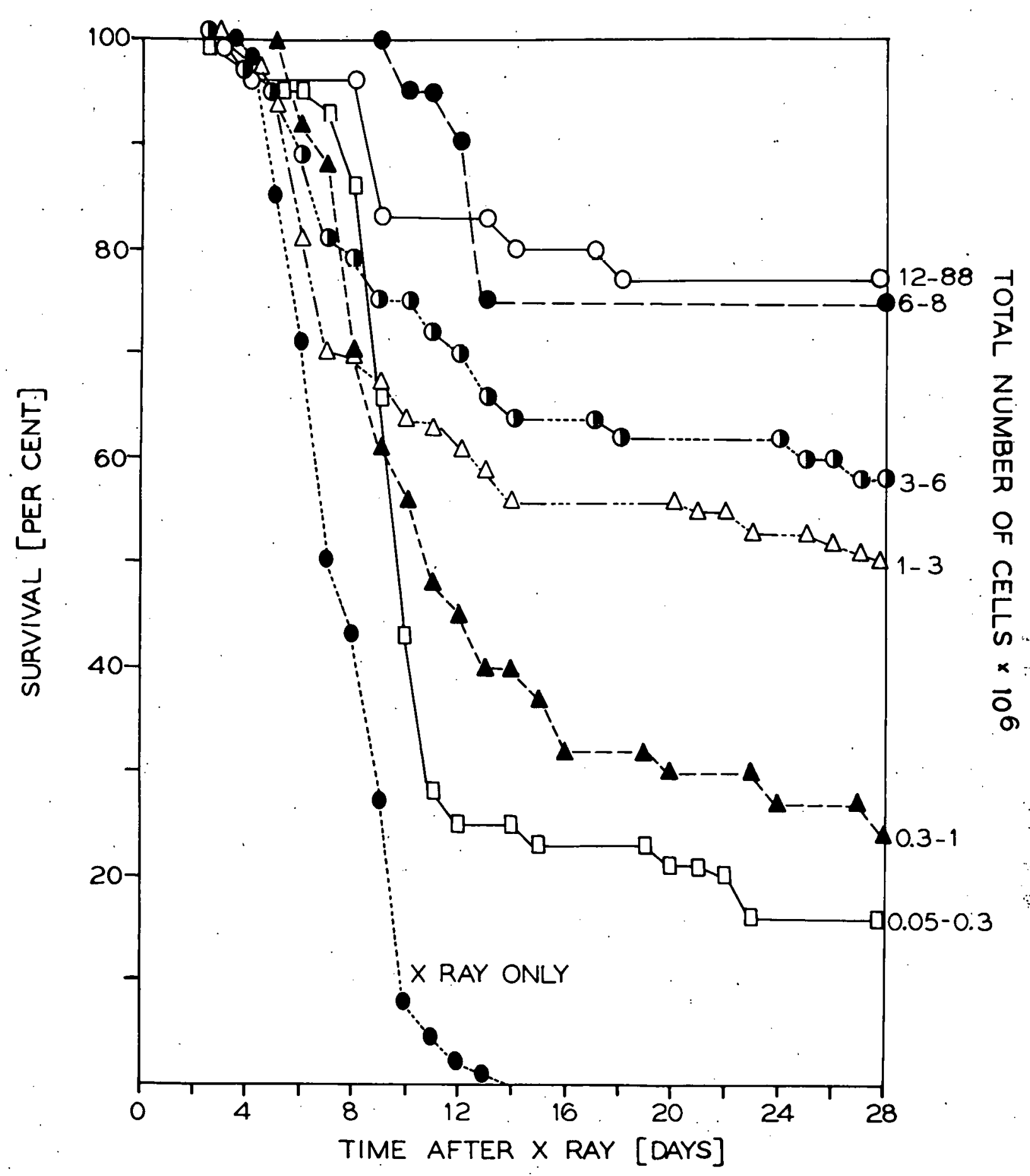

Figure 3. A comparison of the effect of intravenous injections of various concentrations of embryo (liver) cell suspensions on the survival of mice exposed to $900 \mathrm{r}$.

$-11-$ 


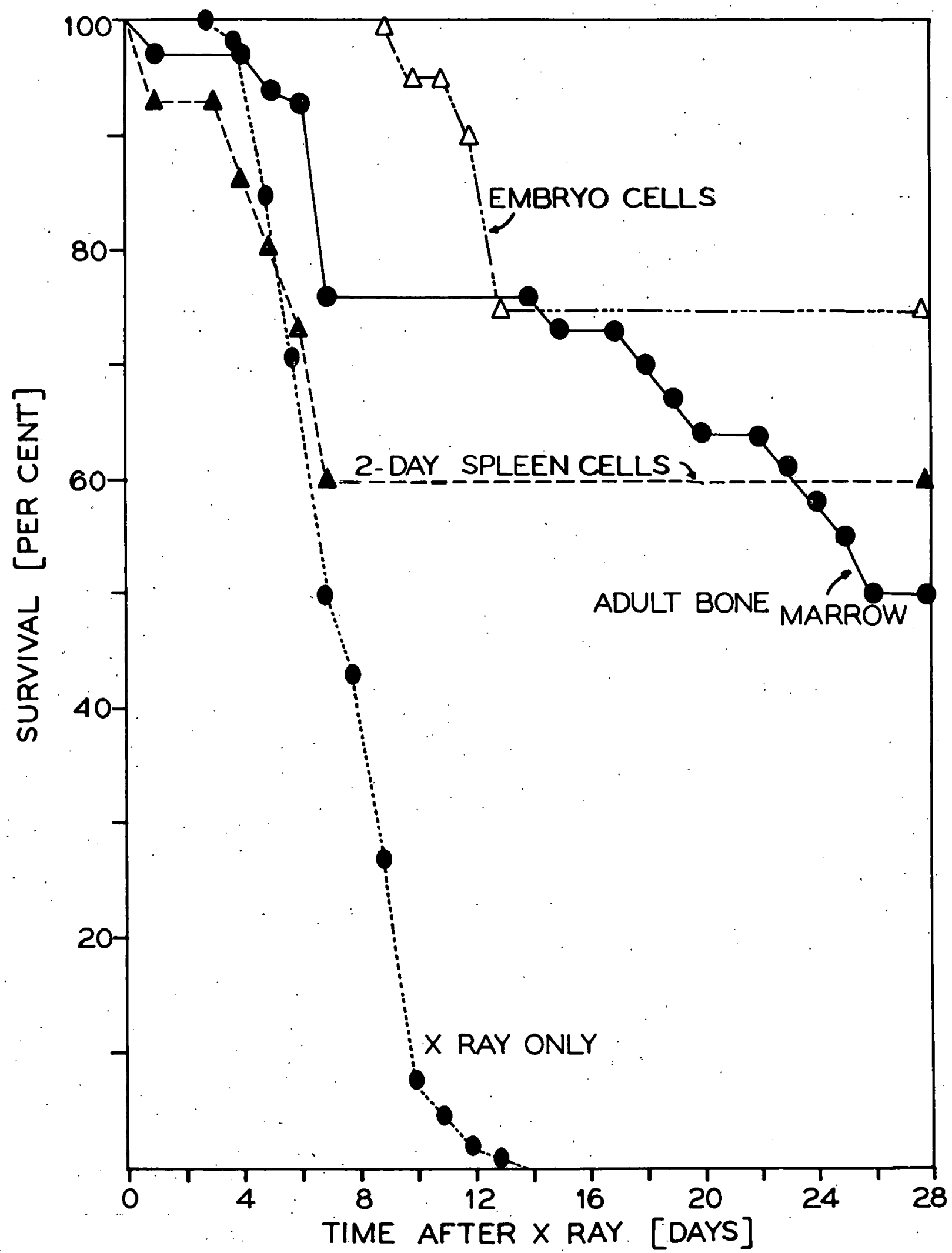

Figure 4. A comparison of the effect of intravenous injections of 6 to $8 \times 10^{6}$ bone marrow, spleen, and embryo cell suspensions on the survival of mice exposed to $900 \mathrm{r}$. 
Table 2

Effect of cells from the liver of 2-day mice on the survival of mice exposed to $900 \mathrm{r}$.

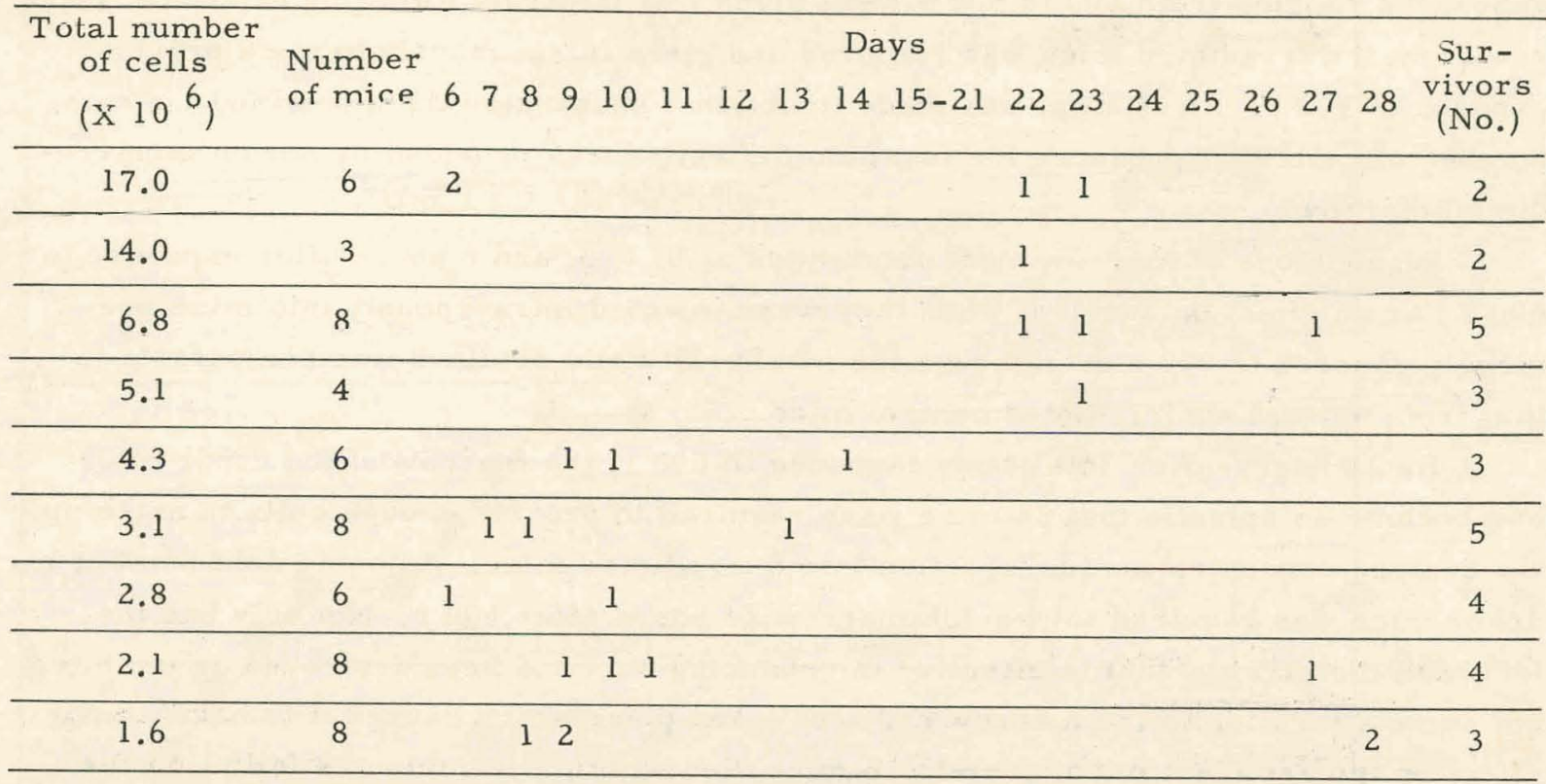

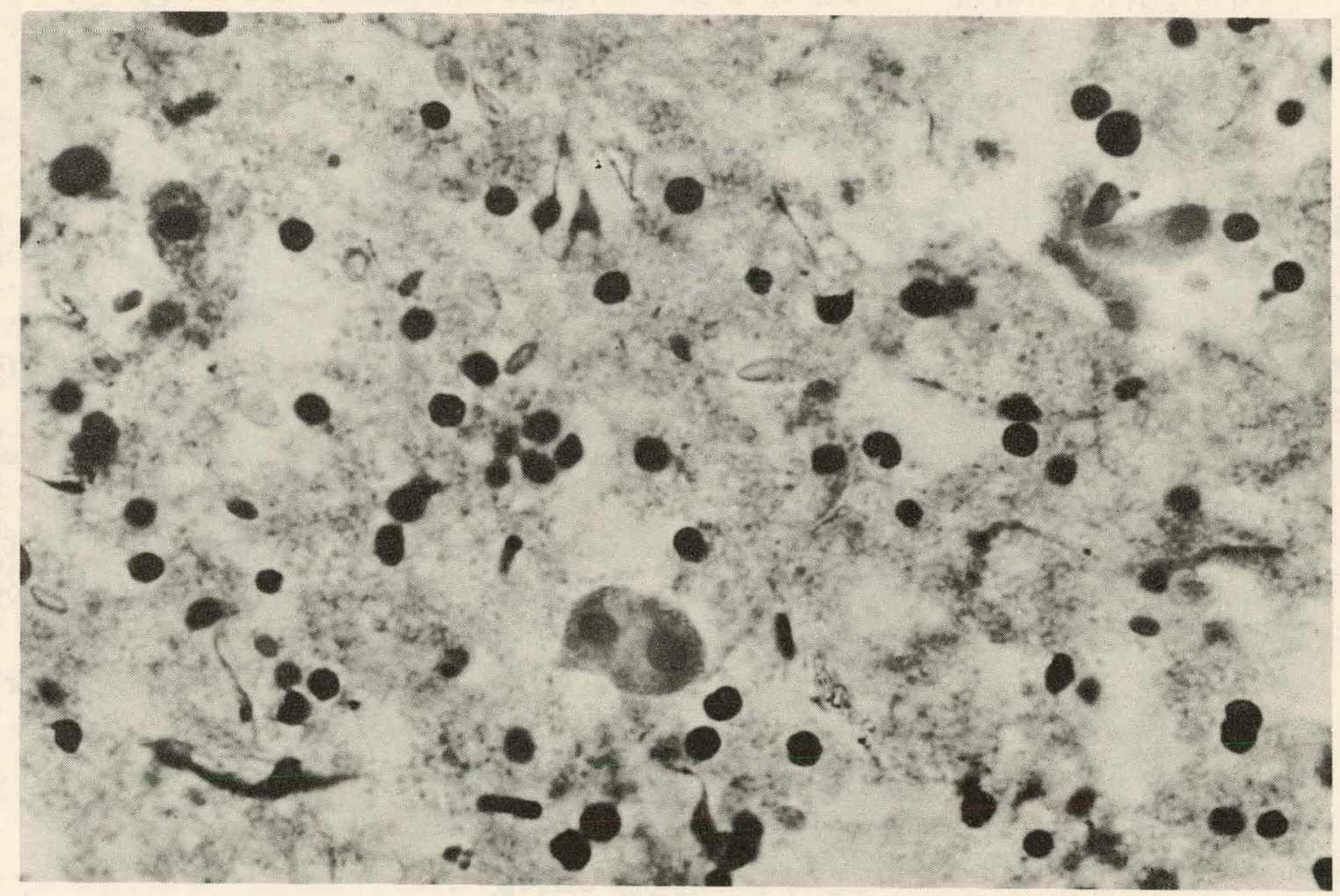

Figure 5. A photomicrograph of a suspension of liver cells from 2-day mice. The cells were suspended in Locke's solution. 
The effect of injections of irradiated bone marrow cells on survival of mice: In some experiments, mice were exposed to $600 \mathrm{r}$ total-body $\mathrm{X}$ radiation. In others, exposures ranging from 100 to $500 \mathrm{r}$ were given. At intervals following exposure, marrow from the irradiated mice was removed and given intravenously to mice previously exposed to $900 \mathrm{r}$. An attempt was made to obtain a suspension that contained the same number of cells that produces the maximum effectiveness provided by normal nonirradiated marrow.

Suspensions of marrow made from mice at $0,1,3$, and 6 hours after exposure to $600 \mathrm{r}$ had no effect on survival when they were injected intravenously into mice previously exposed to $900 \mathrm{r}$ even though the number of cells obtained was comparable to that from normal nonirradiated control mice.

By 18 hours after total-body exposure to $600 \mathrm{r}$, the marrow of the donor mice had become so aplastic that 24 mice were required to provide enough cells to make up the desired concentration for injection into 6 irradiated mice. An equivalent number of donor mice was required to provide marrow 24 hours after $600 \mathrm{r}$. Not only had the factor in the marrow that is effective in enhancing survival been destroyed or inhibited, but some alteration in the marrow had also taken place which caused it to have a toxic effect on the recipient mice. Ten to 18 mice died within a few minutes following the intravenous administration of this suspension, and none survived beyond the 9th day. The manifestation of this "toxic" substance was not apparent during the first 18 hours after irradiation, and no studies have been made to determine how long it persists.

A striking contrast, however, exists between marrow cells taken from a mouse 1 day after it has been irradiated and those taken 8 days after irradiation. Although it was necessary to sacrifice 24 or more animals to obtain enough cells to inject into 4 animals, all 4 survived the 28-day period of observation and no immediate deaths occurred. Later experiments revealed that survival following the administration of 8 day $(600 \mathrm{r})$ marrow, parallels that of mice injected with normal marrow. With a suspension containing about $1.0 \times 10^{6}$ cells from either normal or 8-day $(600 \mathrm{r})$ marrow, 25 per cent of the irradiated recipients survived. Only 10 per cent survived when less than $1.0 \times 10^{6}$ cells were given.

Suspensions of bone marrow cells that were removed from mice 6 days after 600 $\mathbf{r}$ total-body irradiation were injected into mice that had been exposed previously to 900 $r$. Indications are that at 6 days some mechanism is already influencing survival. However, the difficulty encountered in obtaining a sufficient number of cells from such aplastic marrow for a suspension containing about $8.0 \times 10^{6}$ cells has made the extension of this study impractical.

Other studies were made in which the donor mice received smaller amounts of radiation (Figure 6). The marrow from donor mice exposed to 100 or $200 \mathrm{r}$ was as effective as normal marrow in enhancing the survival of mice exposed to lethal amounts of radiation. Marrow removed as early as $\mathrm{l} \mathrm{hr}$ after irradiation was as effective as that removed 3 days later. Indications are that $300 \mathrm{r}$ depresses but does not inhibit 


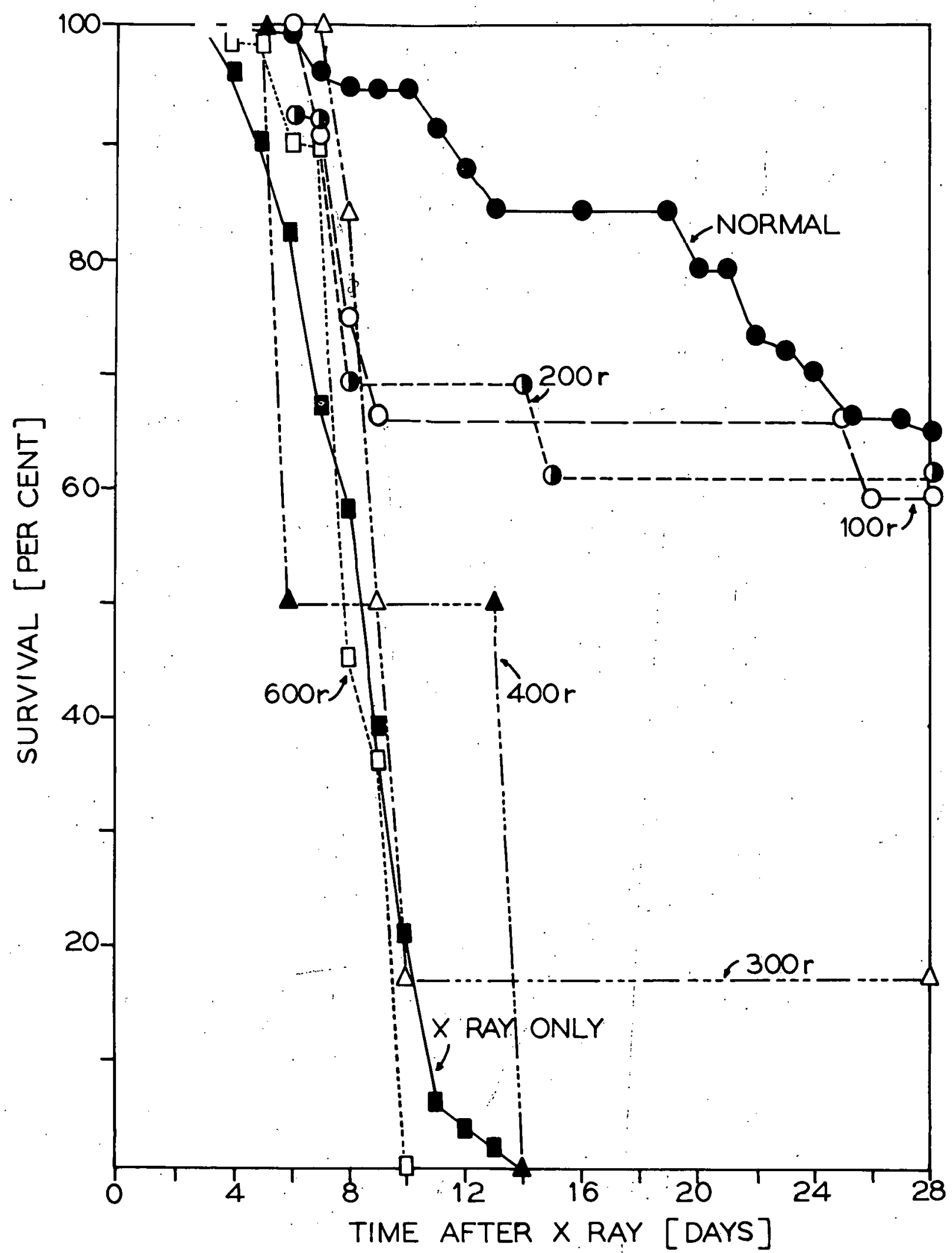

Figure 6. A comparison of the effect of normal marrow and marrow from mice exposed to 100 to $600 \mathrm{r} 1$ day before they were used as donors. 
the activity of the "factor" when the marrow is used 1 day or less after the total-body irradiation. Exposures of 400 or $500 \mathrm{r}$ destroy or inhibit the factor necessary to the survival of irradiated animals when the marrow cells are removed 1 day after $X$ radiation. However, these exposures, like $600 \mathrm{r}$, require many donors and cause a "toxic" effect that is expressed in a fairly high frequency of deaths immediately after intravenous administration of the suspension.

It has been demonstrated recently that the "toxic" effect is present in the supernatant material ${ }^{*}$ of the bone marrow suspensions. Centrifugation and re-suspension of the bone marrow cells in saline or Locke's solution reduces the deleterious effect considerably.

The efficacy of injections of bone marrow and spleen cells from.spleen-shielded animals is being investigated currently.

\section{COMMENTS}

It is obvious from our data that 1) a relatively small total number of cells is sufficient to insure significant survival when they are injected into mice that have been irradiated with $900 \mathrm{r}$, and, 2) embryo liver cells and baby mouse spleen or marrow cells are more effective than adult liver, spleen, or marrow cells. It seems likely that if one were to reduce the total-body exposure of the recipient mice, one might find that an even smaller number of cells would significantly enhance survival. In view of the observation that living cells are effective, it is perhaps important to determine whether the cells of significance are parenchymal or some other cellular constituent of liver, e.g., the Küpfer cells. It should be possible by differential centrifugation of the liver preparations and perhaps of washed spleen and marrow cells to obtain information on the cell type or types concerned in the elaboration of the factor or factors that stimulate the recovery of iriradiated animals.

\section{LITERATURE CITED}

1. Jacobson, L. O., E. K. Marks, E. O. Gaston, M. J. Robson and R. E. Zirkle: The role of the spleen in radiation injury. Proc. Soc. Expt. Biol. Med., 70: 740, 1949.

2. Jacobson, L. O.: Evidence for a humoral factor (or factors) concerned in recovery from radiation injury: A Review. Cancer Research, 12: 315, 1952.

3. Cole, L. J., M. C. Fishler, M. E. Ellis and V. P. Bond: Protection of mice against $\mathrm{X}$-irradiation by spleen homogenates administered after exposure. Proc. Soc. Expt. Biol. Med., 80: 112, 1952.

4. Lorenz, E., C. C. Congdon and D. Uphoff: Modifications of acute irradiation injury in mice and guinea pigs by bone marxow injections. Radiology, 58; 863, 1952.

5. Jacobson, L. O., E. L. Simmons, E. K. Marks and J. H. Eldredge: Recovery from radiation injury. Science, 113: 510,1951.

*Centrifuged at $2500 \mathrm{rpm}$ for 5 minutes. Supernatant was not completely cell-free. 
THE EFFEC'T OF SPLEEN-SHIELDING ON THE HEMATOLOGIC VALUES OF THE BLOOD OF RABBITS FOLLOWING TOTAL-BODY X IRRADIATION"

By

L. O. Jacobson, E. K. Marks, and E. O. Gaston

A single total-body, exposure to $600 \mathrm{r}$ X radiation, which is in the midlethal range, regularly produces a severe anemia, leucopenia, and thrombocytopenia in mice. On the other hand, mice exposed to $600 \mathrm{r}$ with spleen-shielding develop no anemia and a leucopenia and thrombocytopenia of lesser severity and shorter duration. Even with exposure to $1300 \mathrm{r}$, spleen-shielding effectively increases survival and reduces the period of depression of the hematologic constituents of the peripheral blood and the blood-forming tissue to a shorter interval than that in mice exposed to $600 \mathrm{r}$ without spleen-shielding (1). Post-irradiation injection of mashed mouse spleen, embryo suspensions (2), or bone marrow $(2,3)$, and spleen transplantation $(4,5)$ have been: shown to exert an effect on the survival of mice and regeneration of blood-forming tissue that is largely comparable to spleen-shielding. Preliminary studies $(5,6,7)$ in which the spleen-shielding technique has been extended to rabbits have revealed that the effect on survival and on the recovery of blood-forming tissue is not as great as that observed in mice.

In this report, data are presented on the survival of rabbits as well as on the recovery of the peripheral blood and blood-forming tissue following exposure to $800 \mathrm{r}$ total-body $X$ radiation with and without spleen-shielding. Selected data from experiments on rabbits exposed to $800 \mathrm{r}$ with the appendix shielded are added so that comparisons may be made.

\section{MATERIAL AND METHODS}

Swift snuffle-free rabbits of uniform age and weight $(2.5$ to $3.0 \mathrm{~kg})$ were used in this study. The rabbits were maintained on a diet consisting of rabbit pellets, ***arrots, and water ad libitum before and during the experimental procedures described below.

* This paper is a translation of Effets de la protection de la rate pendant l'irradiation totale sur la formule sanguine du lapin. Revue d'Hematologie 8:,515 (1953).

* The 28-day LD50 for Carworth female mice (CF No. 1) is $550 \mathrm{r}$.

* * Purina Rabbit Chow, manufactured by Ralston Purina Co., St. Louis, Mo., consisting of: alfalfa meal, linseed oil meal, ground.oats, dehydrated alfalfa meal, ground grain sorghums, ground yellow corn, wheat gray middlings, soybean oil meal, corn germ meal, molasses, vitamin $B_{12}$ feed supplement, riboflavin supplement, D activated plant sterol, $1.5 \%$ calcium carbonate, $1.5 \%$ low fluorine rock phosphate, $0.25 \%$ iodized salt. 
Experimental procedures: Four groups of animals were studied as indicated in Table 1. Rabbits in group I served as controls. The rabbits in groups II, III, and IV were anesthetized with Nembutal ${ }^{R}$ (38 $\mathrm{mg}$ per $\mathrm{kg}$ of body weight) given intravenously

TABLE 1

Number of animals and treatment of each group.

\begin{tabular}{cccccc}
\hline Group & $\begin{array}{c}\text { X-ray } \\
\text { Exposure } \\
(\mathbf{r})\end{array}$ & $\begin{array}{c}\text { Number of } \\
\text { animals }\end{array}$ & $\begin{array}{c}\text { Spleen } \\
\text { exteriorized }\end{array}$ & $\begin{array}{c}\text { Lead-shielding } \\
\text { of exteriorized } \\
\text { spleen }\end{array}$ & $\begin{array}{c}\text { Total-body } \\
\text { X ray }\end{array}$ \\
\hline I & None & 10 & No & No & No \\
II & None & 9 & Yes & No & No \\
III & 800 & 27 & Yes & Yes & Yes \\
IV & 800 & 29 & Yes & Yes \\
\hline
\end{tabular}

in the marginal ear vein. The hair on the wall of the abdomen was clipped, an incisiun was made in the left upper quadrant, and the spleen was exteriorized. (In another gruup of experiments an identical procedure was used except that the appendix of the rabbit was exteriorized and lead-shielded.) Rabbits in groups III and IV were irradiated with $800 \mathrm{r}$ total-body $\mathrm{X}$ radiation. During irradiation, the mobilized spleen (or appendix) of the rabbits in group IV was placed in a lead shield of $1 / 4 \mathrm{in.} \mathrm{thickness.} \mathrm{These} \mathrm{shields}$ are described in detail elsewhere (7). The mobilized spleens (or appendices) of the rabbits in group II (operated control animals) were placed in.lead shields for a period equal to the time that the spleens (or appendices) of the rabbits in group IV were thus contained. The time required for irradiation was approximately 51 minutes, after which the spleens (or appendices) of the rabbits in groups II, III, and IV were returned to the abdominal.cavity and the operative incisions. were. sutured.

Hematologic studies: Studies of the blood taken from the ear vein of the rabbit included the following:

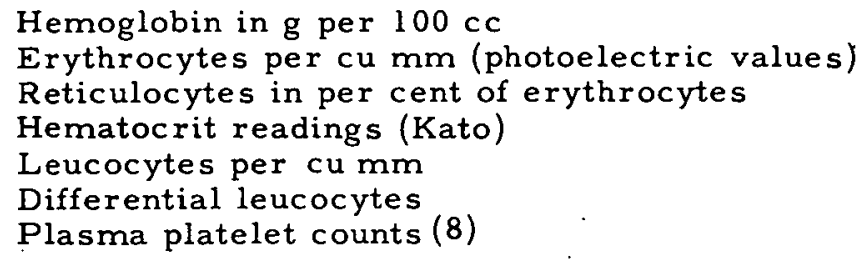

Two control counts were done on each animal before irradiation. After irradiation these studies were repeated on the $3 \mathrm{rd}, 5 \mathrm{th}, 7 \mathrm{th}$, 9th, 12th; 14th, 16th, 21st, $23 \mathrm{rd}$, and 29 th day.

Histologic studies: Histologic studies were made on all four groups of rabbits. Animals from the control and irradiated groups were sacrificed daily for 14 days then at intervals of 3 or 4 days for 35 days after irradiation. At least 2 to 4 animals from each group were sacrificed at each of the intervals, and not infrequently as many as 
8 or 10 were studied during the regenerative period. The tissues taken for study included thymus, liver, sternum, spleen, lymph node from the root of the mesentery, Peyer's patch, appendix, duodenum, adrenal, kidney, bone marrow (femur), and the nvary or testis. The epccimens were fixed in Zenker-formol, embedded in nitrocellulose, sectioned at 6 or $8 \mu$, and stained with hematoxylin-eosin-azure II. In this report, only a resumé of the pertinent histulogic findings are included.

Survival studies: As indicated in Table 2, studies of survival were carried out on both the experimental and control rabbits.

Table 2

Effect of $800 \mathrm{r} X$ radiation on the survival of rabbits with and without spleen-shielding.

Time of death after X-ray

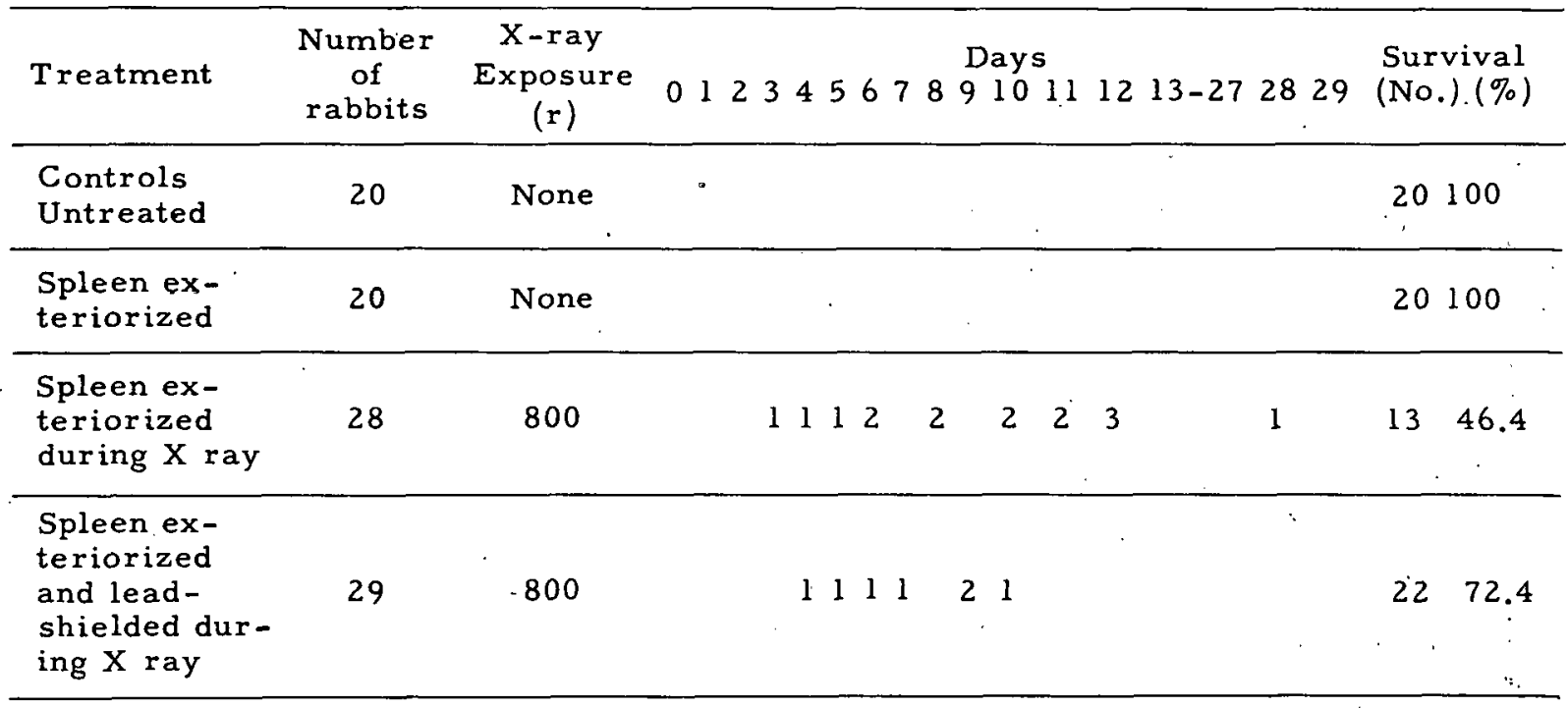

Technique of $\mathrm{X}$ irradiation: The $\mathrm{X}$ rays were generated by a 250 -kvp machine operating at $15 \mathrm{ma}$. A $1.0-\mathrm{mm} \mathrm{Cu}$ filter and a $3.0-\mathrm{mm}$ bakelite filter were used. The half-value layer in $\mathrm{Cu}$ of the filtered beam was $2.0 \mathrm{~mm}$. The exposures were measured with a Victoreen condenser r-meter equipped with a 100-r chamber. Measurements were made in air at the position occupied by the center of the animal's body. 'The exposure rate averaged $15.5 \mathrm{r}$ per minute at $35 \mathrm{in.}$

\section{RESULTS}

Hematologic data from spleen-shielded animals: The erythrocyte, hematocrit, hemoglobin, and reticulocyte values are given in Figures 1, 2, 3, and 4, respectively. These show that no significant difference in the degree of anemia or in the rapidity of 


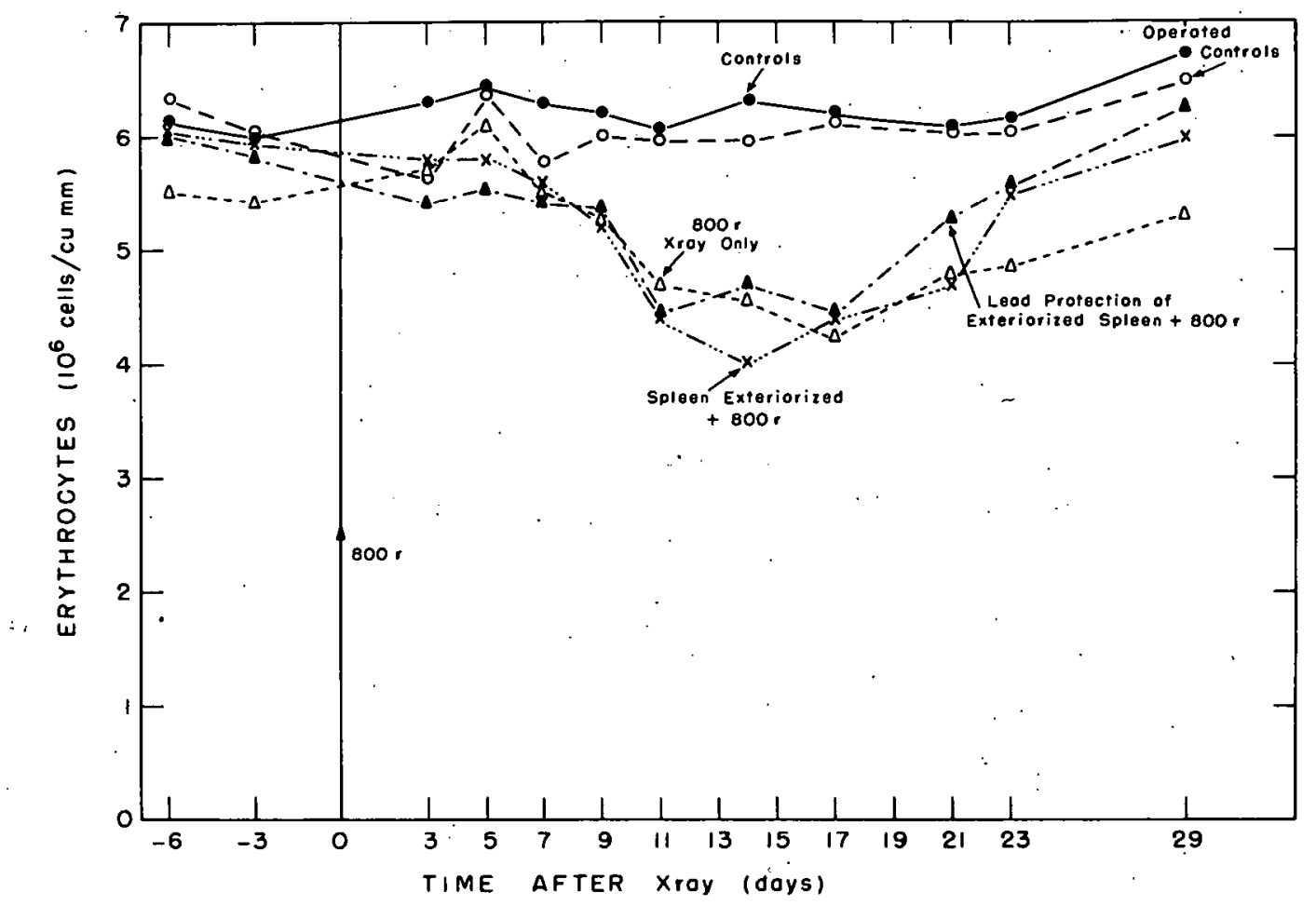

Figure 1. Erythrocyte values of normal rabbits and of rabbits exposed.to $800 \mathrm{r}$ with and without lead-shielding of the spleen.

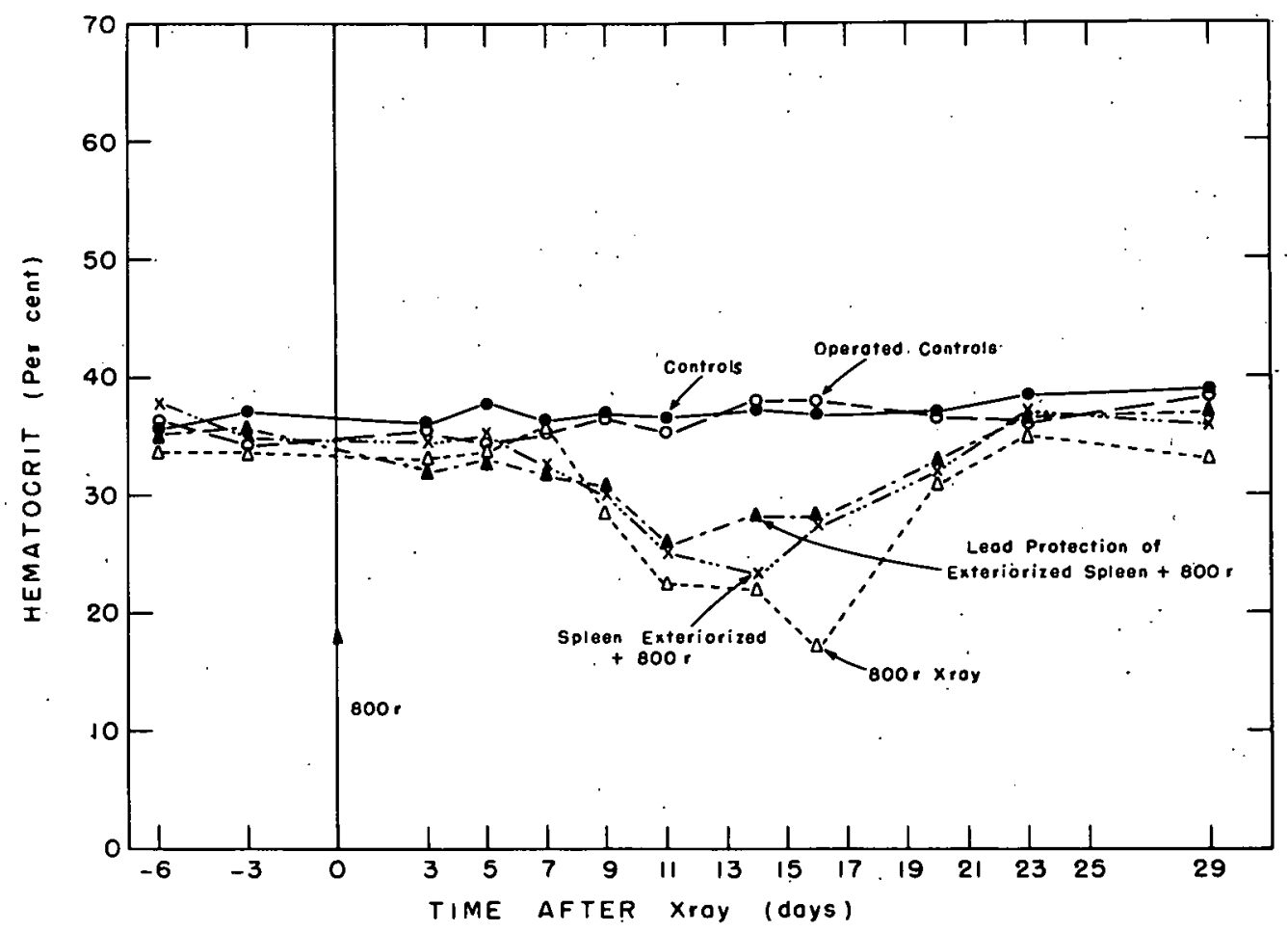

Figure 2. Hematocrit values of normal rabbits and of rabbits exposed to $800 \mathrm{r}$ with and without lead-shielding of the spleen. 


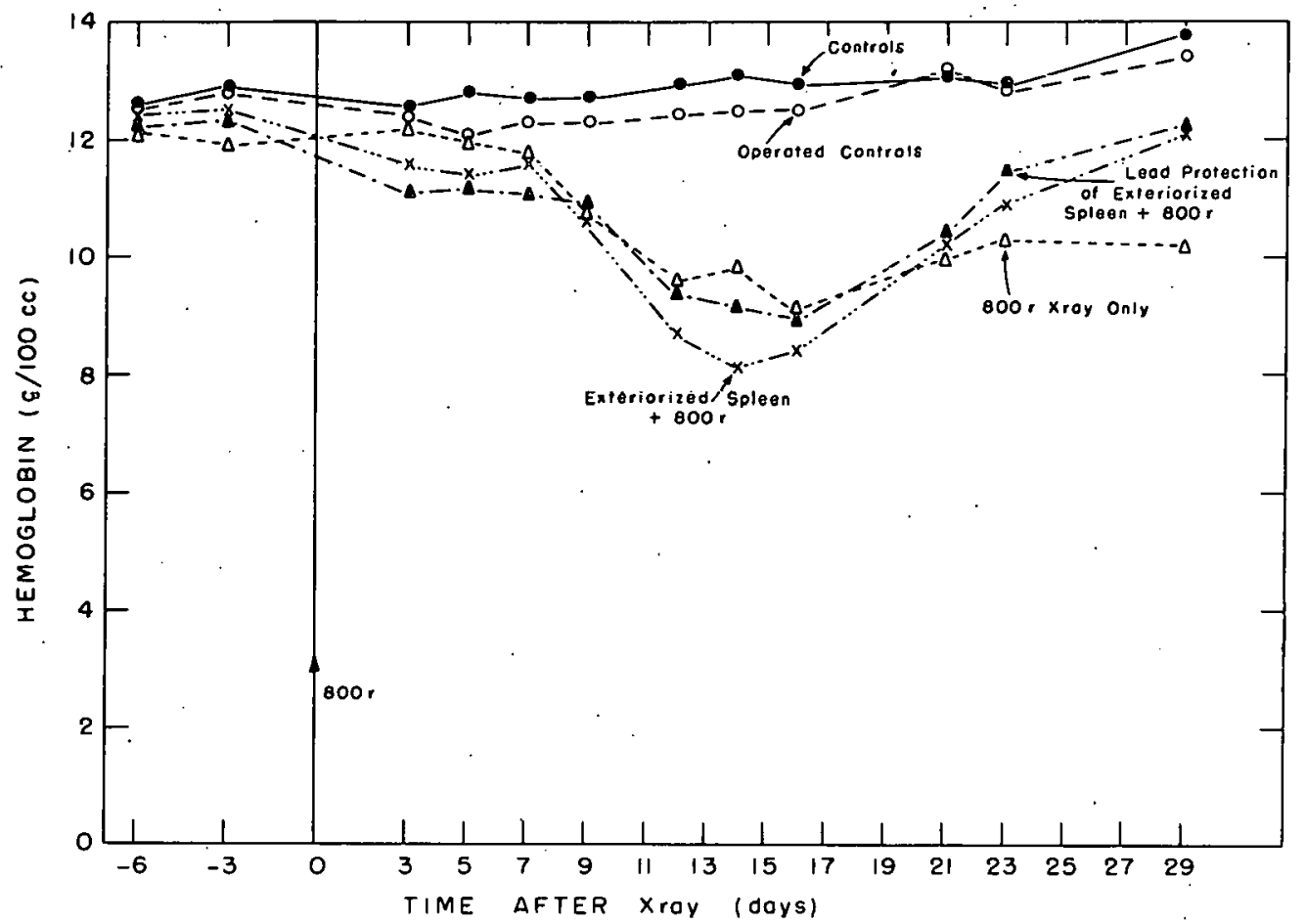

Figure 3. Hemoglobin values of normal rabbits and of rabbits exposed to $800 \mathrm{r}$ with and without lead-shielding of the spleen.

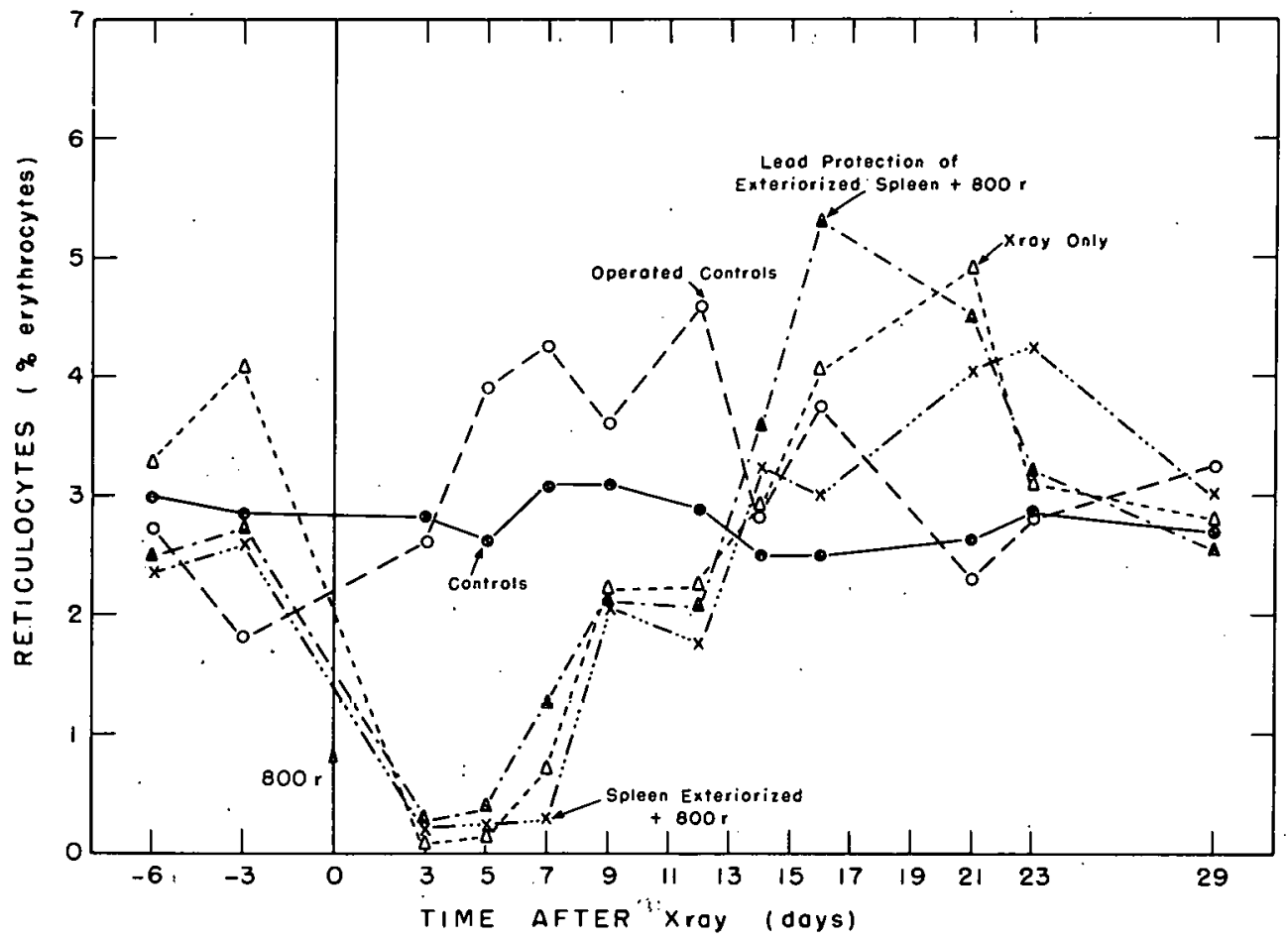

Figure 4. Reticulocyte values of normal rabbits and of rabbits exposed to $800 \mathrm{r}$ with and without lead-shielding of the spleen. 
recovery is apparent between the spleen-shielded and irradiated-control groups. Platelet values were likewise comparable in the spleen-shielded and non-spleen-shielded controls.

The leucocyte values (Figure 5 ) in the 3 irradiated groups were reduced drastically, reaching minimum values by 3 days. The striking difference apparent between the spleen-shielded and non-spleen-shielded groups is that the leucocyte values of the

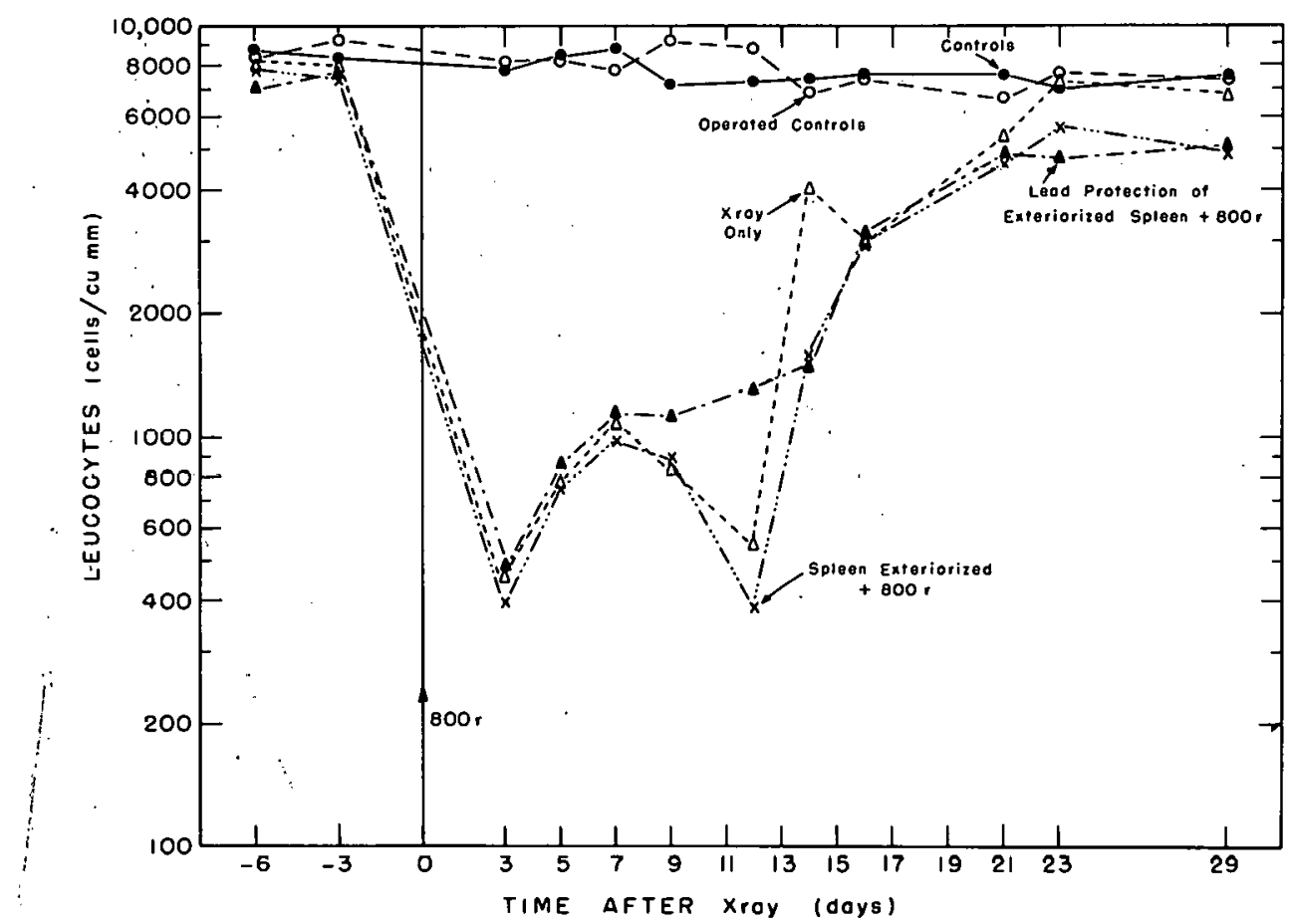

Figure 5. Leucocyte values of normal rabbits and of rabbits exposed to $800 \mathrm{r}$ with and without lead-shielding of the spleen.

former group began to rise between the 3 rd and 5th day after irradiation and continued to rise slowly to normal values (about the 21 st day). On the other hand, the leucocytes of the group without spleen-shielding began to rise at about the same time but fell to the minimum value again between the 9 th and 12 th day. This latter rise and fall, referred to in previous publications $(9,10,11)$ as an "abortive rise," is a common phenomenon that follows total-body irradiation. The heterophil values (Figure 6) parallel those of the absolute leucocytes. The lymphocyte values (Figure 7 ) of the spleen-shielded animals follow a pattern similar to the leucocytes, but full recovery was not apparent even at 29 days when the experiment was terminated.

Hematologic data from appendix-shielded animals: The erythrocyte, hematocrit, reticulocyte, and hemoglobin values of rabbits exposed to $800 \mathrm{r}$ with appendix-shielded were almost identical with those of the spleen-shielded animals described in the preceding section. 


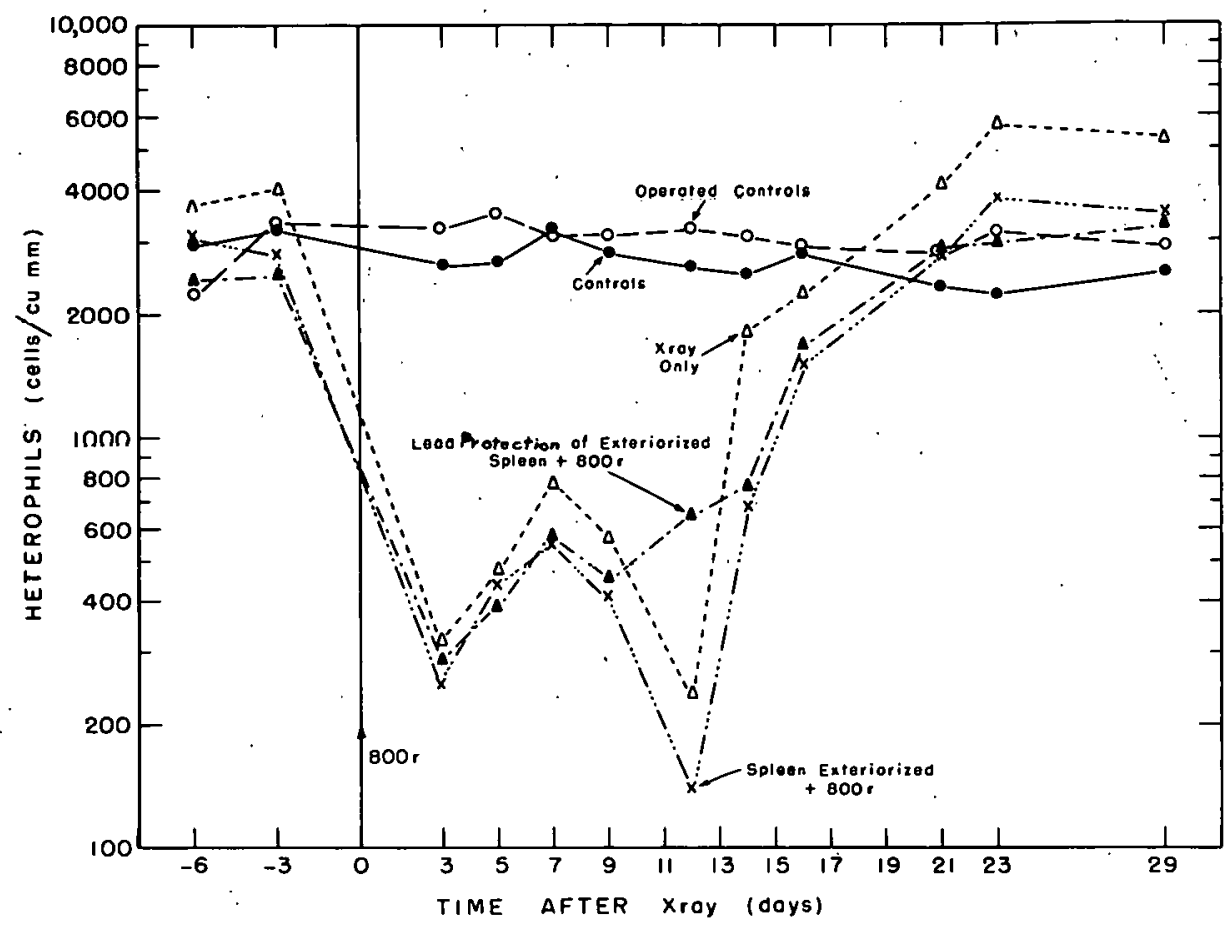

Figure 6. Heterophil values of normal rabbits and of rabbits exposed to $800 \mathrm{r}$ with and without lead-shielding of the spleen.

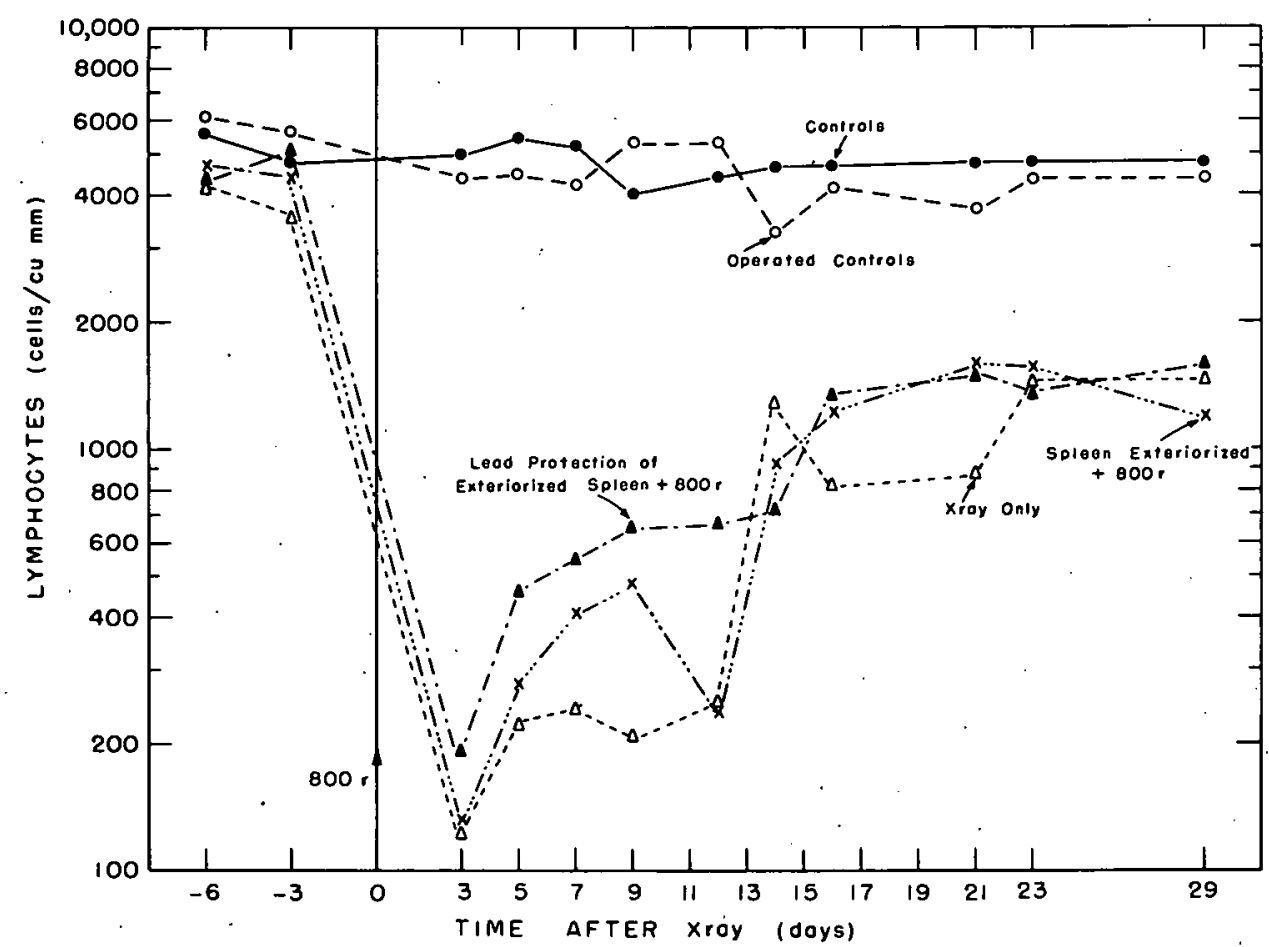

Figure 7. Lymphocyte values of normal rabbits and of rabbits exposed to $800 \mathrm{r}$ with and without lead-shielding of the spleen. 
The abortive rise in the leucocyte, heterophil, and lymphocyte values, observed in the non-appendix-shielded animals, was less prominent in the appendix-shielded animals. In this respect, the appendix-shielded animals were similar to the spleenshielded animals. The striking difference between appendix-shielded animals and spleen-shielded animals is illustrated in Figure 8. Full recovery of the lymphocytes to normal values was apparent.by the 16 th day after irradiation.

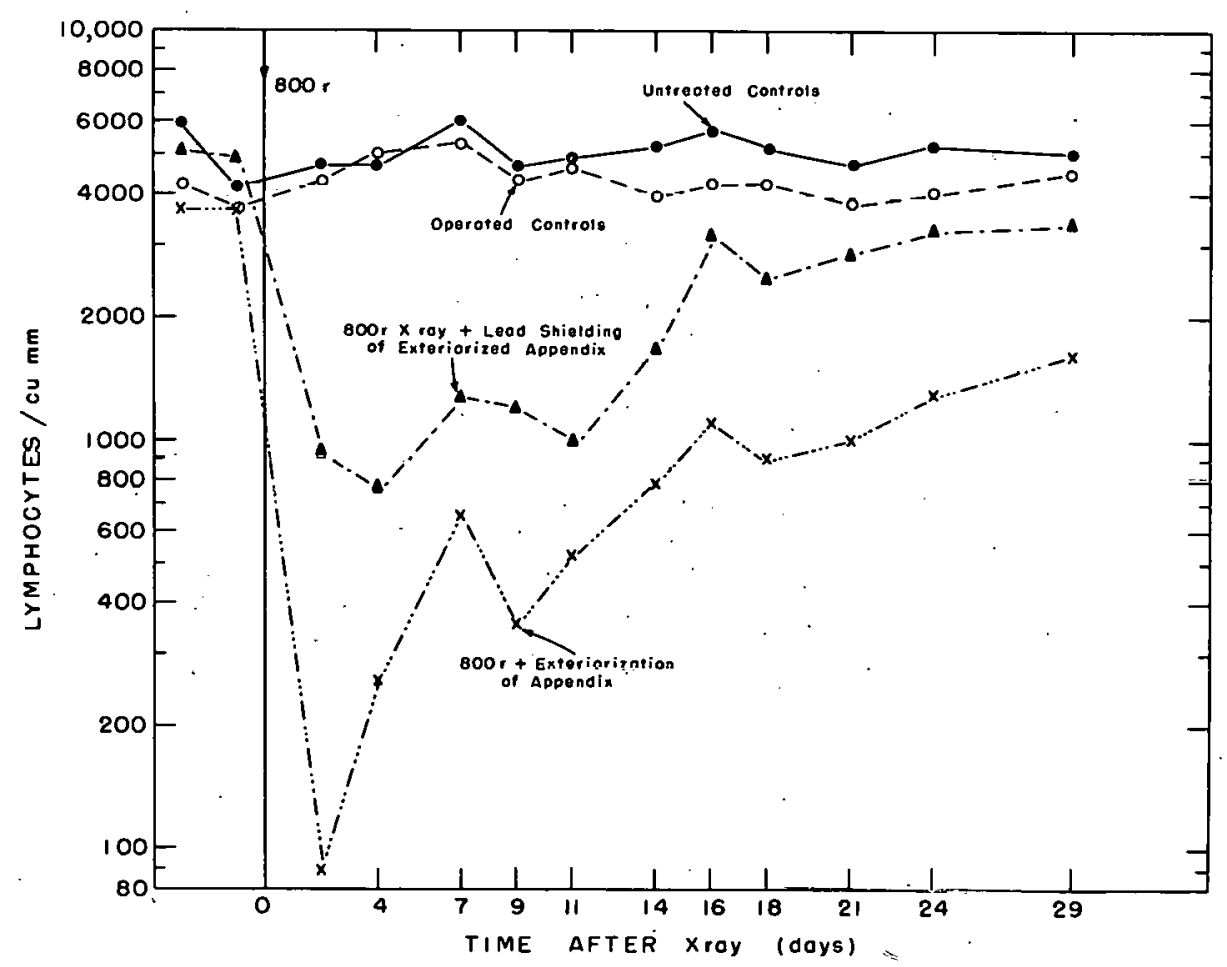

Figure 8. Lymphocyte values of normal rabbits and of rabbits exposed to $800 \mathrm{r}$ with and without lead-shielding of the appendix.

Histologic studies: The effedt of $800 \mathrm{r}$ on the hematopoietic system of the rabbit has been reported in detail by Jacobson (10), Block (12), and Bloom (13), and is only summarized here.

The earlier studies and those described in this communication give evidence that the bone marrow and lymphatic structures undergo: 1) a destructive phase characterized by disintegration of cells; 2) a phase of active phagocytosis of cellular debris; 3) an atrophic phase during which free cells are absent or at a minimum; and finally, 4) a phase of regeneration. The phases of cell destruction and of phagocytosis of debris are largely confined to the first 24 hours following irradiation. The phase of atrophy, in general, persists until the 8th or loth day, or even longer, but the difference between regeneration of lymphatic tissue and bone marrow on the one hand and the rapidity of the regeneration of the various bone marrow cell types on the other requires special 
consideration. Regeneration and complete recovery of the bone marrow invariably precedes full recovery of the lymphatic tissues. In fact, erythrocyte, platelet, and granulocyte precursors are normal in number or exceed normal (conpensatory hypertrophy) in the marrow by the 14th day after irradiation with $800 \mathrm{r}$. This regeneration is reflected in the peripheral blood by a normal or an increased number of reticulocytes, platelets, and heterophils (neutrophils in man).

Before the general and sustained regeneration process is fully established in the bone marrow, abortive attempts at regeneration, especially in the granulocyte series, are observed. This observation has been described by Bloom (15), Block (12), and Jacobson (9) but is emphasized here because of its special significance to this work. Rather diffuse but minimal granulocytopoiesis is apparent in the bone marrow of most animals beginning on about the 4th post-irradiation day. This granulocytopoietic regeneration process increases in amount through approximately the 7 th day, after which granulocyte precursors are virtually absent until about the 1 th day, when they reappear in great numbers and persist. This first diffuse and short-lived regeneration process, referred to by Bloom(15) and Jacobson(19) as an "abortive attempt at regeneration," is reflected in the peripheral blood by a temporary rise in the circulating heterophils (Figure 6) between the $3 \mathrm{rd}$ and 12th days after irradiation. On the other hand, this phenomenon is largely masked, except under special circumstances $(12,16)$, as far as the erythroblast population of the bone marrow or the reticuloyctes of the peripheral blood are concerned. In fact, erythroblasts appear in small numbers beginning on the 4 th or 5th day and gradually increase with less evidence of a return to an atrophic process, as described above for the granulocyte precursors.

The lymphatic tissue, though showing evidence of a diffuse type of regeneration at about the same time as the marrow (circa 4 days), fails to undergo the clear-cut abortive regenerative phenomenon (even though it is apparent in the peripheral blood studies [Figures 7 and 8]) and fails to compensate rapidly. Lymphatic nodules in the lymph nodes and white pulp of the spleen are not yet present by the 14 th day, and the number of lymphocytes in the circulating blood remains below normal for 29 days or more. The thymus regenerates at approximately the same rate as the spleen and lymph nodes from the standpoint of cell population, but it generally fails to attain normal size until after the lymph nodes and spleen have recovered fully.

Regeneration of hematopoietic tissue in spleen-shielded rabbits. Bone marrow: The phase of destruction and phagocytosis of debris was identical to that observed in animals irradiated without spleen shielding. The atrophic period differed in that the early diffuse but minimal appearance of granulocyte precursors at about 4 days was not only sustained but increased gradually so that a relatively normal number of granulocyte precursors was present in most animals by about the 8th post-irradiation day. Figure 9 shows an example of the regenerative process in the marrow of X-irradiated rabbits with and without spleen-shielding. No recurrent atrophy was observed, which 
is so characteristic of animals exposed to $800 \mathrm{r}$ without spleen shielding. No clearly significant difference between the regeneration of erythrocyte precursors in the bone marrow in non-spleen-shielded and spleen-shielded animals was evident.

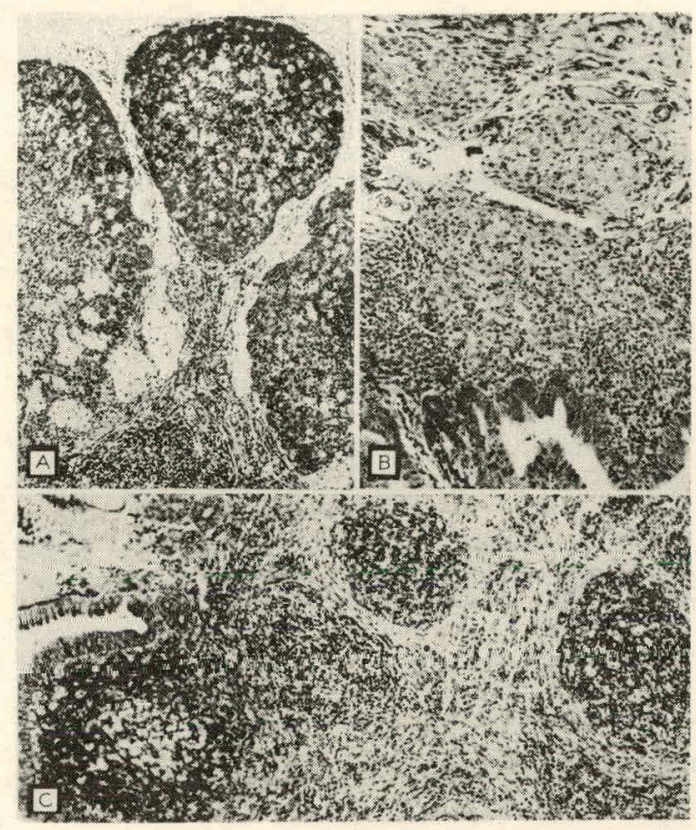

Figure 9. Photomic rugraphs of the bone marrow of rabbits exposed to $800 \mathrm{r}$ with and without lead-shielding of the spleen.

A. Normal rabbit marrow.

B. Atrophic marrow 8 days after $X$ irradiation without spleen-shielding.

C. Regenerating marrow in animal 8 days after exposure with spleen-shielding.

Lymphatic tissue: The spleen of the animals irradiated with spleen-shielding remained essentially unchanged when compared with the spleen of normal non-irradiated rabbits. The amount of ectopic hematopoiesis, erythropoiesis, granulopoiesis, and megakaryopoiesis) increased in the shielded spleen, reaching a peak at about 8 days. The amount, however, was minimal.

The lymph nodes and the appendix of animals that were spleen-shielded were distinctly different from those of the non-spleen-shielded animals. The diffuse recovery process observed in irradiated control animals, beginning at about the 4th day, was more impressive in spleen-shielded animals. In the latter group, a few active nodules were observed in the appendix and lymph nodes beginning on the 4th day. Most animals had scattered active nodules on the $7 \mathrm{th}$, 8th, or 9th day, whereas none was observed before the 14th day in non-spleen-shielded animals (Figure 10).

The regeneration of the thymus seemed to be less remarkable than the regeneration of the lymph nodes in the spleen-shielded animals and followed more or less the pattern observed in the control non-spleen-shielded animals. 
Recovery of hematopoietic tissue in appendix-shielded animals: In the group of rabbits that received $800 \mathrm{r}$ total-body $\mathrm{X}$ irradiation with lead-shielding of the surgically exteriorized appendix, the destruction of the blood-forming tissue was comparable to

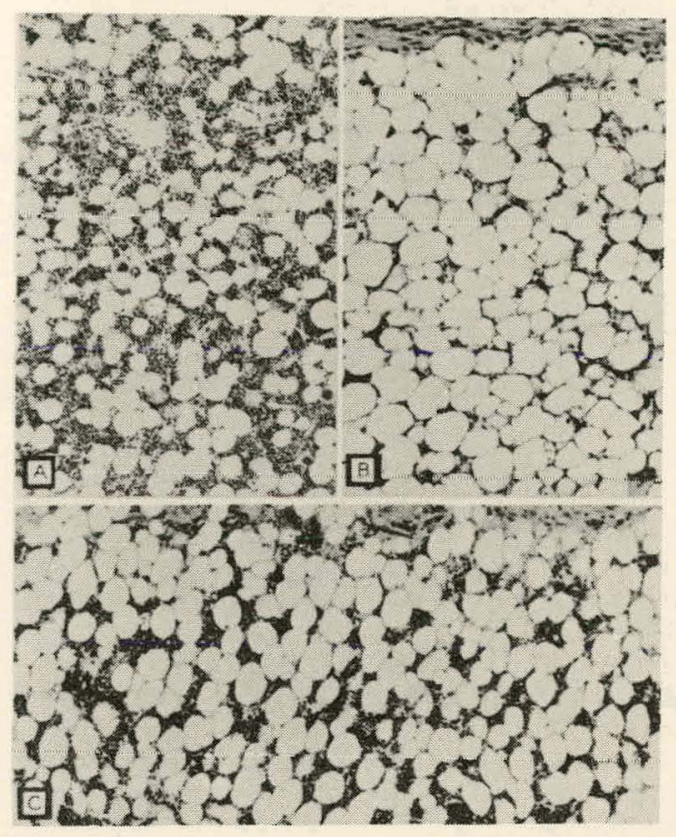

Figure 10. Photomicrographs of the appendix. of rabbits exposed to $800 \mathrm{r}$ with and without lead-shielding of the spleen.

A. Normal rabbit appendix.

B. Atrophic appendix in rabbit 8 days after $\mathrm{X}$ irradiation without spleen-shielding. (Note the 3 nodules that are practically devoid of free cells.)

C. Regenerating appendix of animal 8 days after exposure with spleen-shielding. (Note the 3 active nodules.)

that observed in animals that received the same exposure without shielding. The recovery process in the bone marrow of the appendix-shielded animals was essentially the same as that in the spleen-shielded animals described above. The striking difference between these two shielded groups was in the recovery process in the lymphatic tissues of the appendix-shielded animals. The lymph nodes had active nodules beginning on the 4 th post-irradiation day, and recovery was complete by the 12 th day. The spleen likewise recovered quickly and, in some animals, had recovered completely by 8 days (Figure 11 ).

Survival of spleen-shielded animals: As indicated in Table 2, the survival of spleen-shielded animals was 72 per cent, whereas that of animals without spleen shielding was 50 per cent. In our laboratory for the past 10 years, exposure to $800 \mathrm{r}$ has regularly produced a mortality of 50 per cent in Swift snuffle-free rabbits. 


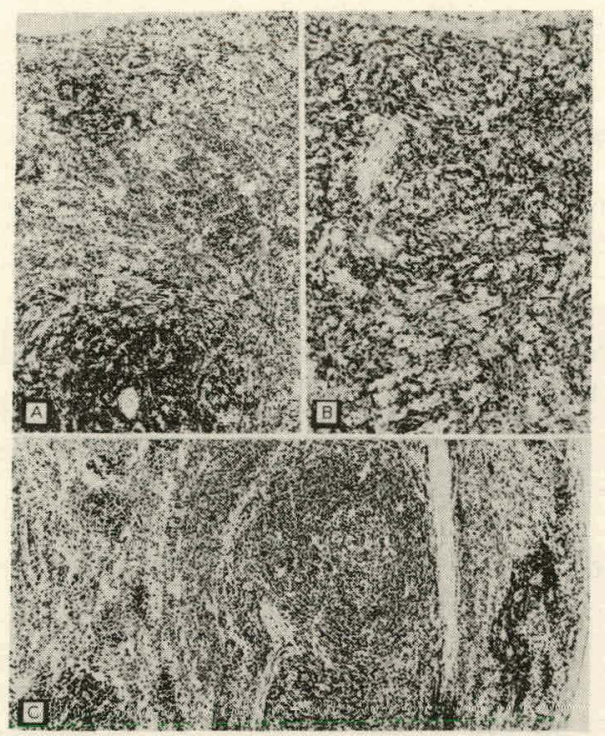

Figure 11. Photomicrographs of the spleen of rabbits exposed to $800 \mathrm{r}$ with and without appendix-shielding.

A. Normal spleen.

B. Atrophic spleen in rabbit 8 days after $\mathrm{X}$ irradiation without spleen- or appendix-shielding. (Note the absence of definitive nodules, the conspicuous absence of lymphocytes, and the prominence of the reticulum stroma.)

C. Regenerating spleen of animal 8 days after exposure with appendix-shielding. (Note the prominent and virtually normal appearance of the white pulp with an active nodule.)

\section{DISCUSSION}

The findings from these experiments are of interest from the standpoint of the difference in species response to shielding or related techniques. The data show that spleen-shielding in the rabbit exerts a minimal but definite effect on: 1) increasing survival and 2) recovery of the hematologic constituents of the peripheral blood.

Appendix-shielding hastens the restoration of the normal number of lymphocytes in the peripheral blood somewhat more effectively than does spleen-shielding. Histologic studies of spleen-shielded and appendix-shielded rabbits support these finding $s$ in the peripheral blood and show, in addition, that lymphatic tissue recovers more rapidly in appendix-shielded than in spleen-shielded rabbits. Comparison of control irradiated and spleen-shielded animals shows that the recovery of the heterophil population in the bone marrow is significantly enhanced by the shielding technique.

It is interesting that on the basis of peripheral blood studies, the minimal but significant difference in the recovery process in the bone marrow between spleenshielded and non-spleen-shielded animals could not be found until after the 9th postirradiation day. Thereafter, heterophil values of non-spleen-shielded animals fell to approximately the same minimal value as that observed on the 3 rd post-irradiation day, 
whereas those of the spleen-shielded animals continued to rise slowly. It has been suggested that this "abortive rise" in granulocyte values represents an abnormal bone marrow population that eventually dies out (9). In the spleen-shielded animals it appears that both a normal and an abnormal population exist at the same time and that the production of normal cells masks, to a large extent, the elimination of the abnormal population.

Since the effect of spleen-shielding or appendix-shielding on the regenerative process in the bone marrow is minimal while recovery of the lymphatic tissues is rather spectacular, it might be postulated that the shielded spleen and appendix of the rabbit produce a substance (or complex of substances) that is effective primarily on the recovery of lymphatic tissues and only minimally effective on bone marrow recovery. In experiments on mice, spleen-shielding or the injection of a suspension of normal mouse spleen cells results in very pronounced regeneration in both the bone marrow and lymphatic tissues of irradiated animals. It is conceivable that since the mouse spleen normally contains a large amount of ectopic erythro-, granulo-, and megakaryopoietic activity as well as lymphatic tissue, it contains or produces a substance (or substances) that is necessary for the recovery of bone marrow and another that is necessary for the recovery of lymphatic tissue. In other words, it is possible that an organ such as the mouse spleen, which continues to produce hematopoietic cells as does the embryonic spleen, has a greater potential for the production of factors involved in regeneration from radiation injury than the more differentiated tissue of the rabbit appendix or spleen.

Of interest is the finding that the capacity of rabbits. irradiated with their appendix or spleen shielded, to produce antibodies in response to an intravenously-administered particulate antigen is retained, whereas this capacity is suppressed in animals irradiated without shielding (7). In fact, the capacity to produce antibodies to an injected antigen is retained in irradiated rabbits even though the originally shielded spleen is removed 24 hours after the shielding-irradiation procedure and the antigen is given 48 hours after the irradiation ( 24 hours after splenectomy) (17). The antigen was administered in the experiments referred to above (both to the experimental and. control animals) when the hematologic constituents (cellular) of the peripheral blood were very low, cell death and phagocytosis of hematopoietic tissue was continuing, and no evidence of regeneration had as yet appeared. Nevertheless, antibody formation was initiated in the spleen-shielded, splenectomized animals but not in the non-spleenshielded animals. Data are also available indicating that the shielded spleen need only remain intact in the circulation for 3 hours after total-body $X$ irradiation of the rabbit to restore significantly the capacity to produce antibodies (18).

These findings in rabbits, when compared with the effect of spleen-shielding $(1,4,5)$ or the injection of bone marrow $(2,3)$, spleen cell suspensions (2), and embryo suspensions (2) on the recovery of mice from irradiation injury, suggest that the mechanism 
of recovery of the hematopoietic system is probably the same in the 2 species. The findings of Congdon and Lorenz (19) and Jacobson (20) that demonstrate that the intravenous administration of rat bone marrow to irradiated mice effectively reduces mortality and hastens recovery of blood-forming tissue lend strong support to the original contention of Jacobson $(6,21)$ that the recovery process thus initiated is on a humoral basis. In other words, a substance, or more likely a complex of substances, produced by the shielded or injected cellular material brings about a functional reconstitution of the cells in the hematopoietic system that were inhibited by irradiation.

If the basic mechanism of recovery from radiation injury in spleen-shielded mice and rabbits is essentially the same even though the observed effect in terms of rapidity of recovery of blood-forming tissue and on survival is less marked in rabbits, then one must conclude that either the shielded spleen in the rabbit is not producing enough of the "humoral" substance or substances to initiate an early and widespread recovery, or that utilization of the substance and perhaps recovery itself proceeds at a slower pace.

If the humoral theory is accepted for purposes of discussion, then one can add that the cell type or types producing the substance (or substances) are not known with any degree of certainty and thus the potential of any given mixed population cannot be assessed adequately. In this connection, the work of Cole and his co-workers (22) is of particular interest. They claim to have prepared suspensions of mouse spleen cells in which only the nuclei of the cells are intact. According to their report, such preparations, administered intraperitoneally to mice that have been given a lethal dose of $X$ radiation, will regularly increase survival. If indeed their suspensions contain no intact cells and thus no living cells in the ordinary sense, then additional proof for the humoral theory is at hand. Since, however, identification of the effective substance or substances in the whole cell or the nucleus still remains to be solved, the need for a simple and sensitive method to assay the activity is obvious. Survival following lethal exposures to radiation is currently being employed to test the effectiveness of various cell suspensions or preparations free from living cells. This method is probably too insensitive for the problem.

\section{SUMMARY AND CONCLUSIONS}

Survival, hematologic, and histologic studies have shown that:

1. Lead-shielding of the surgically exteriorized spleen or appendix of rabbits during total-body exposure to $800 \mathrm{r}$ of $\mathrm{X}$ radiation has a definite but minimal effect on the recovery of bone marrow.

2. Recovery of the lymphatic tissue of spleen-shielded or appendix-shielded

rabbits is definitely. mork rapid than in irradiated-control animals.

3. Recovery of the lymphatic tissue occurs more rapidly in appendix-shielded than in spleen-shielded animals. 
4. Rabbits with shielding of the spleen during total-body exposure to $800 \mathrm{r}$ have a 72 per cent survival as compared with 50 per cent survival in those without spleenshielding.

5. It is suggested that the earlier data and those recorded in this communication indicate that the basic mechanism resulting in enhanced recovery from radiation injury after spleen-shielding or after the employment of related techniques is the same.

\section{LITERATURE CITED}

1. Jacobson, L. O., E. K. Marks, E. O. Gaston, M. J. Robson, and R. E. Zirkle. The role of the spleen in radiation injury. Proc. Soc. Exptl. Biol. Med. 70: 740, 1949.

2. Jacobson, L. O. Evidence for a humoral factor (or factors) concerned in recovery from radiation injury: A review. Cancer Research 12: 315, 1952.

3. Lorenz, E., D. Uphoff, T. R. Reid, and E. Shelton. Modification of irradiation injury in mice and guinea pigs by bone marrow injections. J. Nat. Cancer Inst. 12: 197,1951 .

4. Jacobson, L. O., E. L. Simmons, E. K. Marks, and J. H. Eldredge. Recovery from radiation injury. Science 113: $510,1951$.

5. Jacobson, L. O., E. L. Simmons, E. K. Marks, E. O. Gaston; M. J. Robson, and J. H. Eldredge. Further studies on recovery from radiation injury. J. Lab. Clin. Med. 37: 683,1951.

6. Jacobson, L. O., E. L. Simmons, E. K. Marks, M. J. Robson, W. F. Bethard, and E. O. Gaston. The role of the spleen in radiation injury and recovery. J. Lab. Clin. Med. 35: 746, 1950.

7. Jacobson, L.O., M.J. Robson, and E.K. Marks. The effect of $X$ radiation on antibody formation. Proc. Soc. Exptl. Biol. Med. 75:145, 1950.

8. Skirmont, E., E. K. Marks, and L. O. Jacobson. A modified technique for counting blood platelets. Am. J. Med. Technol. 15: 86, 1949.

9. Jacobson, L. O., E. K. Marks, and E. Lorenz. Heriatologic effects of ionizing radiations. Radiology 52: $371,1949$.

10. Jacobson, L.O., E. K. Marks, E. L. Simmons, C. Hagen, and R. Zirkle. Effect of $\mathrm{X}$ rays on rabbits. Part II: The hematologic effects of total body $\mathrm{X}$ irradiation on the rabbit. McGraw-Hill Book Co., in press.

11. Jacobson, L. O. The hematologic effects of ionizing radiation. Chap. 16, pp. 10311036, McGraw-Hill Book Co., New York, 1953, Ed., A. Hollaender.

12. Block, M. H., L. O. Jacobson, E. K. Marks, and E. O. Gaston. Effects of total-body $\mathrm{X}$ irradiation on a pre-existing induced anemia in rabbits. Part III. Chap. 12, Histopathological Studies, McGraw-Hill Book Co., New York, Ed., R. E. Zirkle.

13. Bloom W. Histopathology of Irradiation from external and internal sources. McGraw-Hill Book Co., New York.

14. Bloom, W. Histopathological changes following radiation exposure. Radiology 49: $344,1947$.

15. Bloom, M. A. Bone marrow. Chap. 6 in Histopathology of irradiation from external and internal sources. McGraw-Hill Book Co., New York, 1948.

16. Jacobson, L. O., E. K. Marks, E. Gaston, and E. Simmons. Effects of total-body $\mathrm{X}$ irradiation on a pre-existing induced anemia in rabbits. I. The response of animals with anemia induced by phenylhydrazine. Chap. 10 in Biological effects of $\mathrm{X}$ and Gamma Radiation. McGraw-Hill Book Co., New York, 1954, Ed., R. E. Zirkle.

17. Jacobson, L. O. and M. J. Robson. Factors effecting X-ray inhibition of antibody formation. J. Lab. Clin. Med. 39: 169, 1952.

18. Jacobson, L. O., and M. J. Robson. Unpublished data.

19. Congdon, C. C., and E. Lorenz. Humoral factor in irradiation protection: Modification of lethal irradiation injury in mice by injection of rat bone marrow. Am. J. Physiol. In press. 
20. Jacobson, L. O. Factors modifying the effect of radiation on the blood and bloodforming tissue. Annals of the New York Academy of Medicine (in press).

21. Jacobson, L. O., E. L. Simmons, W. F. Bethard, E. K. Marks, and M. J. Robson. The influence of the spleen on hematopoietic recovery after irradiation injury. Proc. Soc. Exptl. Biol. Med. 73: 455, 1950.

22. Cole, L. J., M. C. Fishler, and V. P. Bond. Subcellular fraction of mouse spleen radiation protection activity. Federation Proc. 12: 27, 1953. 


\section{COMPARISON OF IN VITRO AND IN VIVO RADIOIRON UPTAKE BY PIGEON ERYTHROCYTES}

By

K. Nakao,** L. Plzak, and W.F. Bethard

\section{SUMMAR Y}

The distribution of iron introduced into red blood cells of pigeons in vivo and in '. vitro has been studied by means of radioactive iron.

Eight one-hundreths $\mu \mathrm{c}(1.5 \mu \mathrm{g})$ of $\mathrm{Fe}^{59}$ was added to $5-\mathrm{ml}$ samples of pigeon whole blood. The samples were then incubated in a water bath maintained at $37^{\circ} \mathrm{C}$ for $15 \mathrm{~min} ., 30 \mathrm{~min} ., 1 \mathrm{hr}, 3 \mathrm{hr}$, or $6 \mathrm{hr}$. Nuclei and stroma were separated from the cytoplasm by Parpart's method $(1)$ and were washed 6 times. The washings were added to the cytoplasm that had been obtained by hemolysis. The hot-pyrophosphate method $(2)$ was used to extract non-hemin iron from the nuclei and stroma. Radioactivity was determined by means of a well-type scintillation counter.

An incubation period of $15 \mathrm{~min}$. was found to be sufficient to permit an appreciable uptake of $\mathrm{Fe}^{59}$ by the erythrocytes, and as the incubation time increased, the uptake also tended to increase (Table l). The iron present in the cytoplasm, which is presumed to be hemoglobin iron for the most part, also increased with the longer

\section{Table 1}

Uptake of $\mathrm{Fe}^{59}$ by pigeon erythrocytes in vitro.

\begin{tabular}{|c|c|c|c|c|c|}
\hline \multirow{2}{*}{$\begin{array}{l}\text { Time of } \\
\text { incubation } \\
\text { (hours) }\end{array}$} & \multirow{2}{*}{$\begin{array}{l}\text { Uptake of } \\
\text { Fe } \mathrm{e}^{59} \text { per } \\
\text { mil of P.R.C. } \\
(\%)\end{array}$} & \multicolumn{2}{|c|}{$\mathrm{Fe}^{59}$ per $\mathrm{ml}$ of P.R.C. } & \multicolumn{2}{|c|}{$\begin{array}{c}\mathrm{Fe}^{59} \text { in } \\
\text { nuclei \& stroma } \\
\text { per ml of P.R.C. }\end{array}$} \\
\hline & & $\begin{array}{c}\text { cytoplasm } \\
(\%)\end{array}$ & $\begin{array}{c}\text { and stroma } \\
\qquad(\%)\end{array}$ & $\begin{array}{c}\text { non-hemin } \\
(\%)\end{array}$ & $\begin{array}{c}\text { hemin**** } \\
(\%)\end{array}$ \\
\hline $\begin{array}{c}\text { Exp. } 1 \\
1 / 4 \\
1 / 2 \\
1 \\
6\end{array}$ & $\begin{array}{l}1.69 \\
3.78 \\
4.84 \\
8.30\end{array}$ & $\begin{array}{l}43.2 \\
70.8 \\
74.2 \\
84.0\end{array}$ & $\begin{array}{l}59.6 \\
42.4 \\
25.2 \\
11.0\end{array}$ & $\begin{array}{r}43.0 \\
31.2 \\
14.6 \\
6.3\end{array}$ & $\begin{array}{r}16.6 \\
11.2 \\
10.6 \\
4.7\end{array}$ \\
\hline $\begin{array}{r}\text { Exp. } 2 \\
1 \\
3\end{array}$ & $\begin{array}{l}4.06 \\
7.18\end{array}$ & $\begin{array}{l}60.2 \\
71.3\end{array}$ & $\begin{array}{l}41.2 \\
28.2\end{array}$ & $\begin{array}{l}31.0 \\
21.0\end{array}$ & $\begin{array}{r}10.2 \\
7.2\end{array}$ \\
\hline
\end{tabular}

*The complete text appears in Science (in press).

* Rockefeller Foundation Fellow.

$* *$ Hemin $F e^{59}$ obtained by the subtraction of non-hemin $F e^{59}$ from percentage of $F e^{59}$ in nuclei and stroma. 
periods of incubation. However; the uptake of $\mathrm{Fe}^{59}$ by the nuclei and stroma, which was at first relatively high, decreased as incubation was continued.

Several investigators $(3,4,5)$ have observed the presence of non-hemin iron in avian red blood cells but none has been able to find its exact localization. In our attempt to localize this substance, we made a non-hemin extraction on the nuclei and stroma. The data in Table 1 show that the per cent of non-hemin iron in the nuclei and stroma is very high, particularly during the early stage of incubation. Tishkoff et $\underline{a l}^{(6)}$ and Moskowitz et al. ${ }^{(7)}$ suggest that the presence of labeled hemin iron in the nuclei and stroma fractions may be explained by contamination by hemoglobin or by the incorporation of the radioactive iron into some other hemin compounds in these cellular components.

For in vivo studies, various amounts of $\mathrm{Fe}^{59}$ were injected intravenously into pigeons, and blood samples were taken by cardiac punctuxe at appropriate time intervals thereafter. The samples were analyzed for $\mathrm{Fe}^{59}$ content as were those used for the in vitro studies. The data for two birds are given in Table 2 .

Table 2

Uptake of $\mathrm{Fe}^{59}$ by pigeon erythrocytes in vivo.

\begin{tabular}{|c|c|c|c|c|c|}
\hline \multirow{3}{*}{$\begin{array}{l}\text { Time after } \\
\text { injection } \\
\text { (hours) }\end{array}$} & \multirow{3}{*}{$\begin{array}{l}\text { Uptake of } \\
\text { Fe } e^{59} \text { per } \\
\text { ml. of P.R.C. } \\
(\%)\end{array}$} & \multicolumn{2}{|c|}{$\mathrm{Fe}^{59}$ per ml. of P.R.C. } & \multirow{2}{*}{\multicolumn{2}{|c|}{$\begin{array}{c}\mathrm{Fe}^{59} \text { in } \\
\text { nuclei and stroma } \\
\text { per ml. of P.R.C. }\end{array}$}} \\
\hline & & \multirow{2}{*}{$\begin{array}{c}\text { cytoplasm } \\
(\%)\end{array}$} & \multirow{2}{*}{$\begin{array}{c}\text { nuclei } \\
\text { and stroma } \\
(\%)\end{array}$} & & \\
\hline & & & & $\begin{array}{c}\text { non-hemin } \\
(\%)\end{array}$ & $\begin{array}{c}\text { hemin } \\
(\%)\end{array}$ \\
\hline \multicolumn{6}{|c|}{ Exp. 3 (Pigeon weighing $320 \mathrm{~g}$ to which $22 \mu \mathrm{g}(1.2 \mu \mathrm{C})$ of $\mathrm{Fe}^{59}$ was given.) } \\
\hline $\begin{array}{c}1 / 2 \\
1-1 / 2 \\
2 \\
3\end{array}$ & $\begin{array}{l}1.18 \\
1.64 \\
1.66 \\
1.88\end{array}$ & $\begin{array}{l}92.5 \\
93.4 \\
97.0 \\
93.5\end{array}$ & $\begin{array}{l}8.12 \\
7.70 \\
7.60 \\
8.00\end{array}$ & $\begin{array}{l}1.12 \\
1.24 \\
1.11 \\
2.11\end{array}$ & $\begin{array}{l}7.00 \\
6.46 \\
6.49 \\
5.89\end{array}$ \\
\hline \multicolumn{6}{|c|}{ Exp. 4 (Pigeon weighing $359 \mathrm{~g}$ to which $18 \mu \mathrm{g}\left(0.96 \mu \mathrm{c}\right.$ of $\mathrm{Fe}^{59}$ was given.) } \\
\hline $\begin{array}{c}1 / 2 \\
2 \\
3 \\
4\end{array}$ & $\begin{array}{l}0.62 \\
1.35 \\
1.81 \\
2.20\end{array}$ & $\begin{array}{l}92.5 \\
92.0 \\
93.5 \\
94.0\end{array}$ & $\begin{array}{l}7.42 \\
8.07 \\
6.19 \\
6.00\end{array}$ & $\begin{array}{l}3.80 \\
4.06 \\
2.65 \\
1.90\end{array}$ & $\begin{array}{l}3.62 \\
4.01 \\
3.54 \\
4.10\end{array}$ \\
\hline
\end{tabular}

The per cent of $\mathrm{Fe}^{59}$ taken up per $\mathrm{ml}$ of packed red cells in vivo was much lower during the period of measurement than that in the in vitro experiments. This is undoubtedly explained by the fact that in vivo the iron is taken up primarily by the erythroid precursors in the bone marrow and thus, a more extended measuring time is required to allow for the appearance of the matured cells in the peripheral blood.

The uptake of $\mathrm{Fe}^{59}$ by nuclei and stroma in vivo (Table 2) was much lower than that taken up by these components in vitro. However, the cytoplasmic uptake was considerably higher. 
Table 3 gives the data from studies that.were designed to determine whether there is a difference in the nature of the non-hemin iron in the nuclei and stroma in vivo and in vitro. For these experiments, whole blood was incubated with $\mathrm{Fe}^{59}$ for

Table 3

Per cent of non-lemin iron in the nuclei and stroma in vivo and in vitro.

\begin{tabular}{|c|c|c|c|c|c|}
\hline \multirow{2}{*}{$\begin{array}{l}\text { Tirre of ite- } \\
\text { incubation } \\
\text { (hours) }\end{array}$} & \multirow{2}{*}{$\begin{array}{l}\mathrm{Fe}^{59} \\
\text { per } \mathrm{l} \mathrm{ml} \text {. } \\
\text { of P.R.C. } \\
(\%)\end{array}$} & \multicolumn{2}{|c|}{$\mathrm{Fe}^{59}$ per ml. of P.R.C. } & \multicolumn{2}{|c|}{$\begin{array}{c}\mathrm{Fe}^{59} \text { in } \\
\text { nuclei. \& stroma } \\
\text { per ml. of P.R.C. }\end{array}$} \\
\hline & & $\begin{array}{l}(\%) \\
i\end{array}$ & $\begin{array}{l}\text { and stroma } \\
(\%)\end{array}$ & $\begin{array}{c}\text { non-hemin } \\
(\%)\end{array}$ & $\begin{array}{c}\text { hemin } \\
(\%)\end{array}$ \\
\hline $\begin{array}{l}\text { Section A } \\
\text { Before re- } \\
\text { incubation } \\
1 \\
3\end{array}$ & $\begin{array}{r}100.0 \\
85.6 \\
57.0\end{array}$ & $\begin{array}{l}37.1 \\
42.0 \\
45.2\end{array}$ & $\begin{array}{l}64.8 \\
50.0 \\
20.0\end{array}$ & $\begin{array}{l}56.4 \\
41.5 \\
15.1\end{array}$ & $\begin{array}{l}8.4 \\
8.5 \\
4.9\end{array}$ \\
\hline $\begin{array}{l}\text { Section B } \\
\text { Before re- } \\
\text { incubation } \\
1 \\
3\end{array}$ & $\begin{array}{r}100.0 \\
85.3 \\
79.8\end{array}$ & $\begin{array}{l}25.4 \\
33.5 \\
35.3\end{array}$ & $\begin{array}{l}72.8 \\
57.0 \\
49.4\end{array}$ & $\begin{array}{l}59.8 \\
39.3 \\
38.5\end{array}$ & $\begin{array}{l}13.0 \\
18.7 \\
10.9\end{array}$ \\
\hline $\begin{array}{l}\text { Section C } \\
\text { Before re- } \\
\text { incubation } \\
1 \\
3\end{array}$ & $\begin{array}{r}100.0 \\
80.5 \\
72.4\end{array}$ & $\begin{array}{l}25.4 \\
32.7 \\
36.5\end{array}$ & $\begin{array}{l}72.8 \\
53.6 \\
44.2\end{array}$ & $\begin{array}{l}59.8 \\
47.5 \\
30.1\end{array}$ & $\begin{array}{r}13.0 \\
5.1 \\
14.1\end{array}$ \\
\hline $\begin{array}{l}\text { Section D } \\
\text { Before re- } \\
\text { incubation } \\
1 \\
3\end{array}$ & $\begin{array}{r}100.0 \\
97.2 \\
91.2\end{array}$ & $\begin{array}{l}81.0 \\
81.2 \\
81.2\end{array}$ & $\begin{array}{l}20.4 \\
17.8 \\
16.8\end{array}$ & $\begin{array}{r}12.1 \\
10.0 \\
8.0\end{array}$ & $\begin{array}{l}8.3 \\
7.8 \\
8.6\end{array}$ \\
\hline
\end{tabular}

15 min., washed 3 times with iron-free physiologic saline, and then reconstituted to its original concentration in iron-free saline (section A), saline containing $107 \mu \mathrm{g}$ of stable iron (section B), or in pigeon plasma containing $105 \mu \mathrm{g}$ of serum iron (section C). Samples were then reincubated for 1 or $3 \mathrm{hr}$. One pigeon was injected intravenously with $0.64 \mu \mathrm{c}(12 \mu \mathrm{g})$ of $\mathrm{Fe}^{59}$ and was bled $18 \cdot \mathrm{hr}$. later. The red cells were incubated in iron-free saline (section $D$ ).

The radioactive iron was found to leave the cells in vitro during reincubation in any of the media that were used. The per cent of $\mathrm{Fe}^{59}$ in the cytoplasm, however, increased during reincubation, while that in the nuclei and stroma declined. This suggests that the non-hemin iron in the nuclei and stroma may.be utilized for the synthesis of hemoglobin and that it may be in equilibrium with the iron in the suspending medium. In contrast, iron taken up in vivo is comparatively stable, and the slight drop 
that was seen may be attributed to the non-hemin iron fraction of the nuclei and stroma.

It is quite possible that the iron taken up by pigeon erythrocytes in vitro is at first attached or combined loosely to the surface of the cells and that it may be in equilibrium with their iron content, particularly that of the nuclei and stroma.

\section{LITERATURE CITED}

1. Parpart, A. The preparation of red cell membranes. J. Cellular Comp. Physiol. $19: 248(1942)$.

2. Brückmann, G. and S. G. Zondik. An improved method for the determination of non-hemin iron. J. Biol. Chem. 135:22 (1940).

3. Jensen, W. N., H. Ashenbrucker, G. E. Cartwright, and M. M. Wintrobe. The uptake in vitro of radioactive iron by avian erythrocytes. J. Lab. Clin. Med. $42: 833$ (1953).

4. Burmester, B. R. A chemical and spectrophotometric study of immature red blood cells, Folia Hermatolog 56:372 (1937).

5. Rostorfer, H. H. Comparison of methods for measurement of avian hemoglobin. J. Biol. Chem., 80:901 (1949).

6. Tishkoff, G. H., F.S. Robschreit-Robbins, and G. H. Whipple. Red cell stroma in dogs. Variations in the stroma protein and lipid fractions related to exper:imental conditions. Blood 8:459 (1953).

7. Moskowitz, M. and M. Calvin. On the components and structure of the human red cell membrane. Exp. Cell Research 3:33 (1951). 
STUDIES ON THE MECHANISM OF HEMOLYSIS

IN PRIMAQUINE-SENSITIVE NEGROES * **

By

R. J. Dern, I. M. Weinstein, D. W. Talmage

G.V. T.eRoy, and A. S. Alving

\section{SUMMARY}

Primaquine, which is one of the most potent anti-malarial drugs, induces an acute hemolytic anemia in a small group of susceptible individuals ${ }^{(1,2)}$. A mild anemia often develops in Caucasians ${ }^{(3)}$ who are given this drug in therapeutic amounts ( $30 \mathrm{mg}$ base daily for 14 days), but acute crises are limited almost exclusively to members of heavily pigmented races. Hockwald ${ }^{(4)}$, for example, has observed a 5 per cent incidonce of arute hemnlysis in a group of 110 male American Negroes.

The purpose of this investigation was to learn whether the hemolytic defect that develops during primaquine administration is due to an abnormality of the erythrocyte or to extracorpuscular factors.

All of the subjects of this study were volunteers from the Illinois State Penitentiary at Stateville with the exception of one student at the University of Chicago. The "primaquine-sensitive"*** men were healthy American Negroes who had never had malaria. Primaquine-nonsensitive Negroes and Caucasians were studied to establish their hematologic stability during the course of treatment. The student was included in the investigation because he had been splenectomized two years previously. In other respects, he was considered to be normal.

Radioactive sodium chromate was added to heparinized donor's blood in such amounts that a $70-\mathrm{ml}$ aliquot would contain 200 to $300 \mu \mathrm{c}$ of radioactivity. The blood wast then incubated for $1 \mathrm{hr}$ at room temperature, and then the cells were washed twice with physiologic saline. The blood was reconstituted with saline to the original volume. Seventy $-\mathrm{ml}$ aliquots of the labeled cell suspension were injected into each recipient. Recipients were compatible with the donor in respect to the following factors: $A, B, \mathrm{Rh}_{\mathrm{O}}^{\prime}(\mathrm{D}), \mathrm{rh}^{\prime}(\mathrm{C}), \mathrm{rh}^{\prime}$ ' (E), and $\mathrm{Hr}_{\mathrm{o}}(\mathrm{c})$.

*The complete paper entitled "The hemolytic effect of primaquine. I. Localization of the druginduced hemolytic defect in primaquine-sensitive individuals" appears in J. Lab. Clin. Med. 43:303 (1954).

* This investigation was carried out under contract no. DA-49-007-MD-20 between the Office of the Surgeon General, U.S.A. and the Department of Medicine, The University of Chicago.

***; This does not imply a sensitization in the immunological sense but refers to the development of the hemolytic reaction. 
Blood drawn at intervals of several days was heparinized, and 2 3-ml samples were each counted for 2 l-min. periods in a 7-ml Kahn tube in a well-type scintillation counter. Corrections were made for background and isotopic decay. Each corrected count was then a measure of the per cent of labeled cells in the recipient at the time that the sample was withdrawn. The survival curves that are presented are based upon the apparent survival of the erythrocytes. Necheles et al. (5) have shown that this is a valid measure of the true survival curve.

Group I: Labeled blood from a primaquine-sensitive Negro was injected into a group of normal Negroes and Caucasians and some was reinjected into the donor. During a 4- to 10-day control period, samples of blood were drawn daily from each recipient, and the per cent of labeled cells was determined. Approximately one-half of the group was given orally a therapeutic course of primaquine for from 7 to 14 days, and blood samples were taken for the duration of the experiment.

The fate of the labeled cells in normal recipients is shown in Figure 1 . When $30 \mathrm{mg}$. of primaquine base was given daily, the curves dropped sharply while those

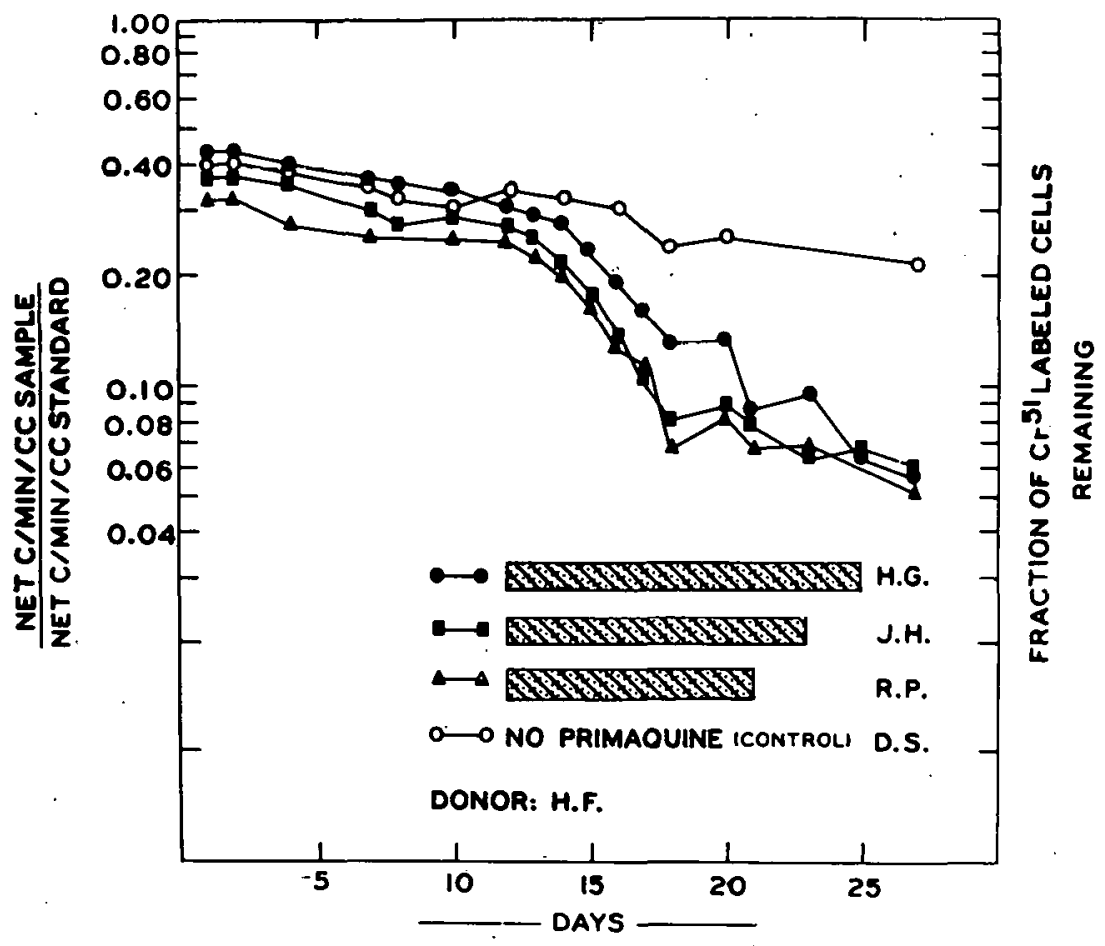

Figure 1. The fate of red blood cells transfused from a primaquine-sensitive voluntee $r$ into normal (nonsensitive) men during primaquine administration. Solid symbols: primaquine, 30 $\mathrm{mg}$. base daily for the period indicated by the hatched block. Hollow symbols: no drug (control). H.G.; D.S. and R.P.: Caucasian recipients. J.H.: Negro recipient. Donor H.F.: primaquinesensitive Negro. 
for the normal controls, who did not receive primaquine, were not altered. Splenectomy did not affect the survival of the transfused cells (Figure 2).

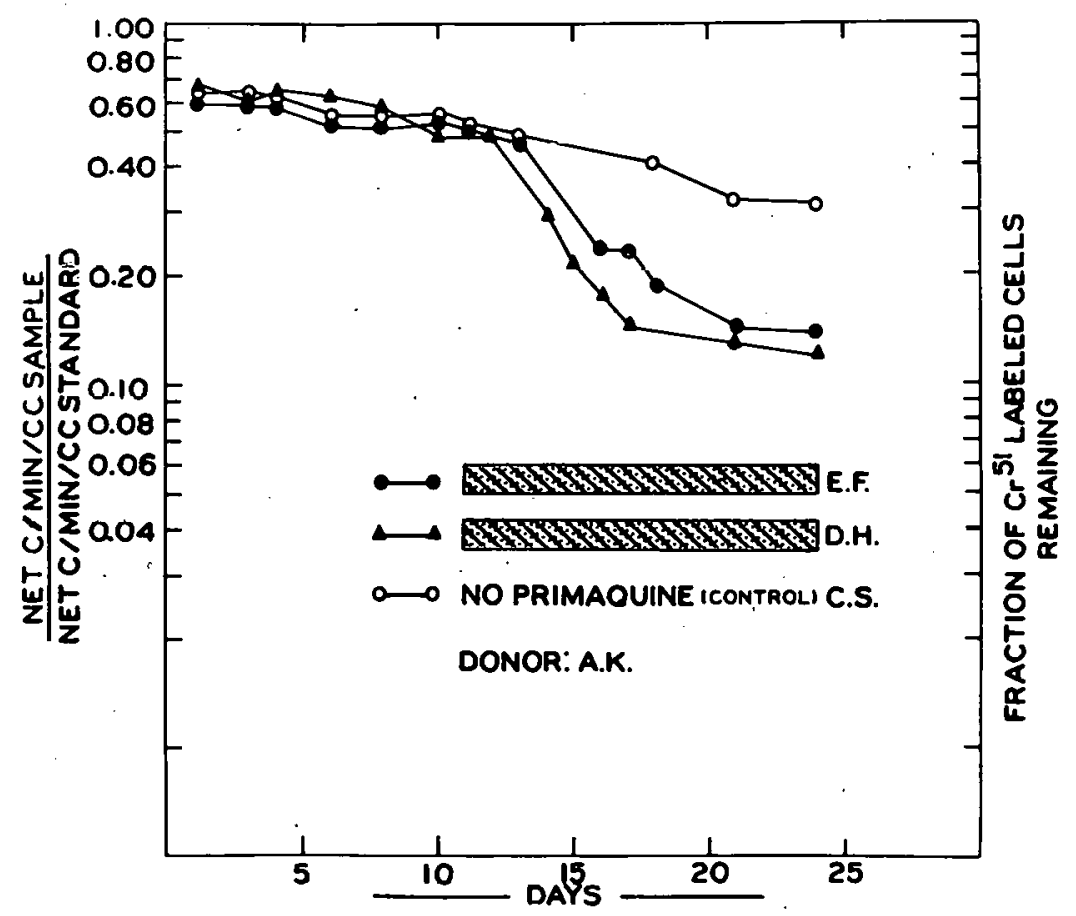

Figure 2. The fate of red blood cells transfused from a primaquine-sensitive volunteer into normal (nonsensitive) men during primaquine administration. Solid symbols: primaquine, $30 \mathrm{mg}$. base daily for the period indicated by the hatched block. Hollow symbols: no drug (control). E.F., D.H. and C.S.: Caucasian recipients. D.H.: splenectomized Caucasian recipient.

Donor A.K.: primaquine-sensitive Negro.

Forty to 60 per cent of the primaquine-sensitive cells were found to be destroyed at 7 days after the administration of the drug had been started. This approximates the degree of anemia that is seen when the drug is given to primaquinesensitive patients for 7 days.

There was no change in hemoglobin concentration, hematocrit, serum bilirubin, serum iron, and fecal urobilinogen in any of the men that were studied. The Coombs test gave negative results for all subjects throughout the course of the investigation.

Group II: Red cells from normal men were labeled and injected into other normal men and into primaquine-sensitive Negroes. After a control period, $30 \mathrm{mg}$ base of primaquine was administered daily to one-half of the group. Blood samples were drawn at frequent intervals and their radioactivity was determined.

When primaquine was given to sensitive subjects, the normal transfused cells were not hemolyzed (Figures $3 \mathrm{~A}$ and $4 \mathrm{~A}$ ). However, the erythrocytes of the recipient 
underwent hemolysis, and a severe anemia developed (Figures $3 B$ and $4 B$ ). There was no change in the hemoglobin or hematocrit values of the controls. There was no evidence of sickling in the red cells of the primaquine-sensitive men, and the Coombs test gave negative results throughout the periods of induced hemolysis.
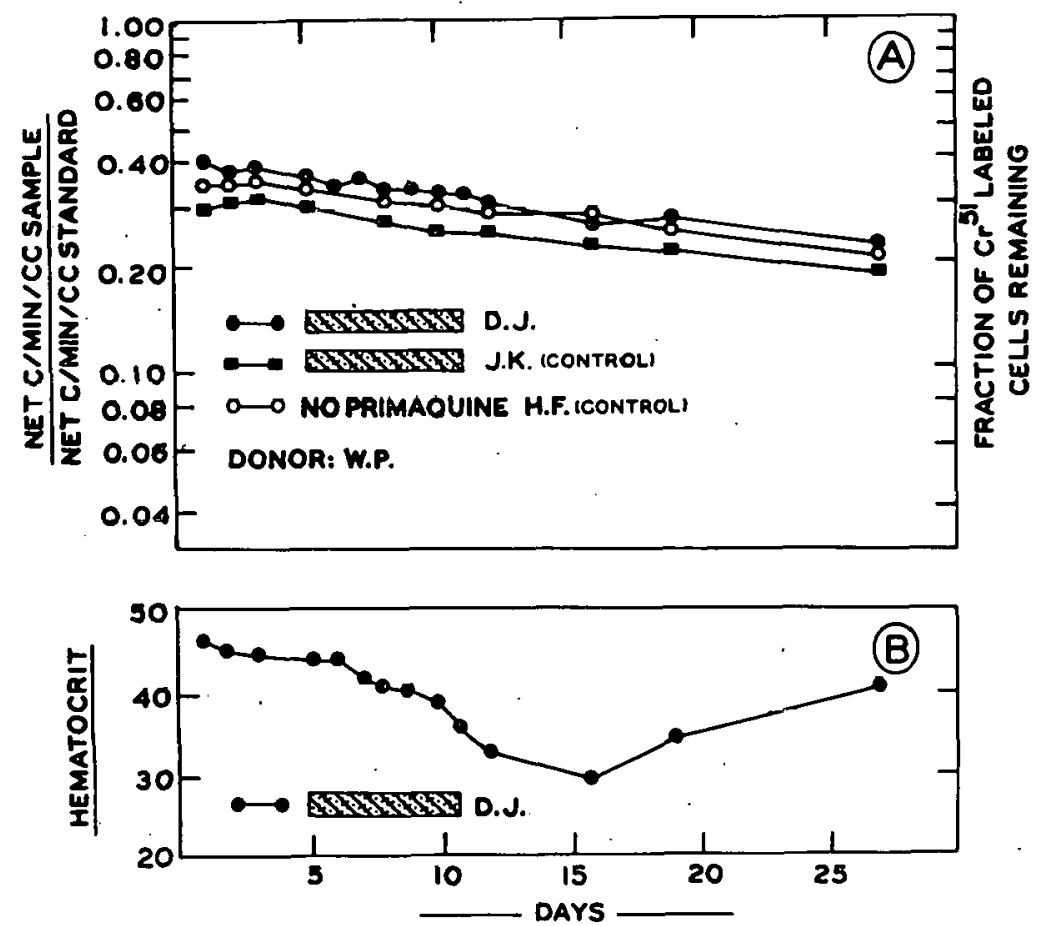

Figure 3. The fate of red blood cells transfused from a normal (nonsensitive) man into primaquine-sensitive volunteers during primaquine administration. Solid symbols: primaquine, $30 \mathrm{mg}$. base daily for the period indicated.by the hatched block. Hullow symbols: no drug (control). J. K.: Caucasian recipient. D. J. and H. F.: primaquine-sensitive Negro recipients. Donor W. P.: normal (nonsensitive) Negro.

A. Red Cell survival curves.

B. Hematocrit determinations during hemolytic episode induced by primaquine in $D$. $J$.

The results of these experiments are evidence that the drug-induced hemolysis that occurs in primaquine-sensitive subjects is due to a unique susceptibility of the red blood cell rather than to an extracorpuscular defect. 


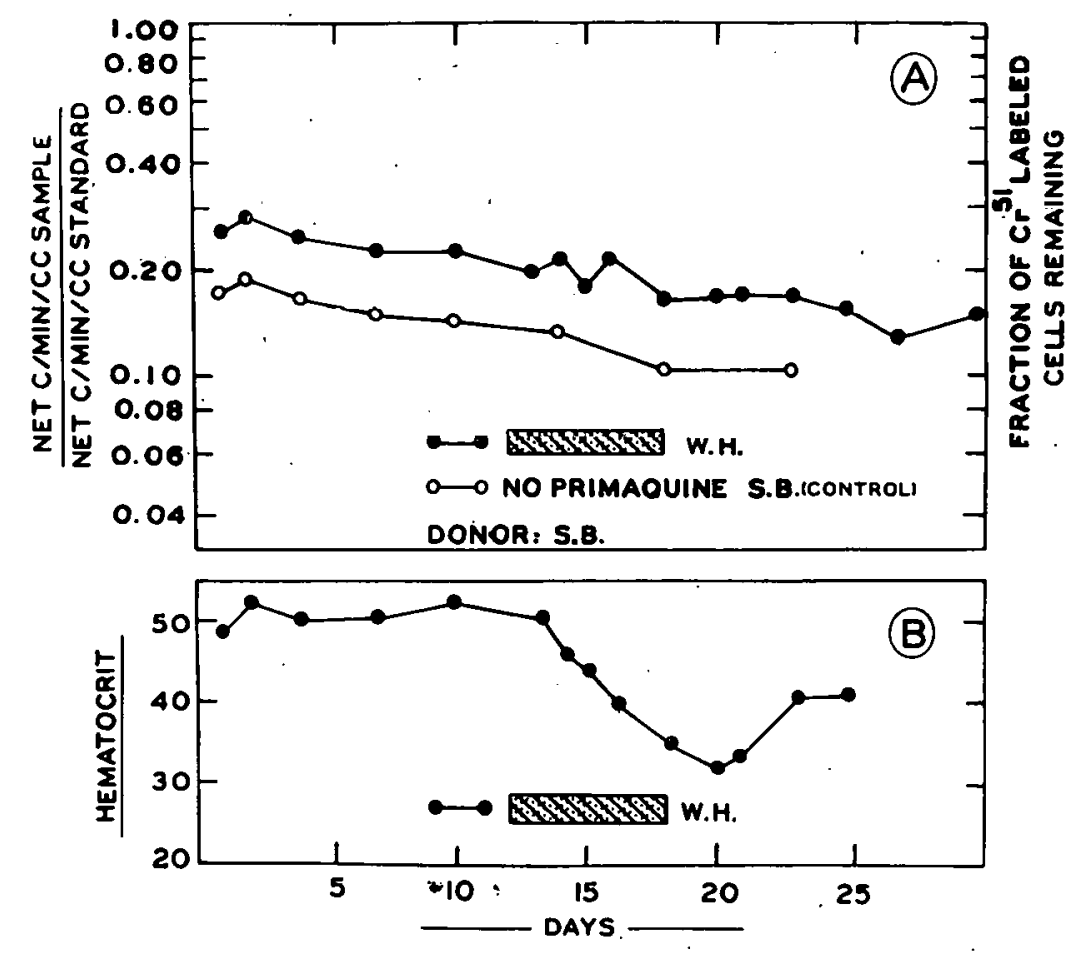

Figure 4. The fate of red blood cells transfused from a nurmal (nonsensitive) man into primaquine-sensitive volunteers during primaquine administration. Solid symbols: primaquine, $30 \mathrm{mg}$. base daily for the period indicated by the hatched block. Hollow symbols: no drug (control). W.H.: primaquinesensitive Negro recipient. S.B.: Normal (nonsensitive) Negro recipient (control). Donor S.B.: Normal (nonsensitive) Negro. A. Red cell survival curves

B. Hematocrit determinations during hemolytic episode induced by primaquine in W. $\mathrm{H}$.

\section{LITERATURE CITED}

1. Earle, D. P., Jx., F. S. Bigelow, C. B. Zubrod, and C. A. Kane. Studies on the chemotherapy of the human malarias. IX. Effect of pamaquine on the blood cells of man. J. Clin. Investigation 27: 121 (1948).

2. Coatney, G.R., W. C. Cooper, D. E. Eyles, W. B. Culwell, W. C. White, and H. A. Lints. Studies in human malaria. XXVII. Observations on the use of pentaquine in the prevention and treatment of Chesson strain vivax malaria. J. Nat. Malaria Soc. 9: $222(1950)$.

3. Clayman, C. B., J. Arnold, R. S. Hockwald, E. H. Yount, Jr., J. H. Edgcomb, and Alf S. Alving. Status of primaquine. III. Toxicity of primaquine in Caucasians. J. A. M. A. 149: 1558 (1952).

4. Hockwald, R. S., J. Arnold, C. B. Clayman, and Alf S. Alving. Status of primaquine. IV. Toxicity of primaquine in Negroes. J. A. M. A. 149: 1558 (1952).

5. Necheles, T.F., I.M. Weinstein, and G. V. LeRoy. Radioactive sodium chromate for the study of survival of red blood cells. I. The effect of radioactive sodium chromate on red cells. J. Lab. Clin. Med. 12 : 358 (1953). 


\title{
DECREASED RED CELL SURVIVAL TIMES ASSOCIATED WITH LIVER DISEASES
}

AS MEASURED WITH RADIOACTIVE SODIUM CHROMATE*

By

\author{
P. N. Jones, ${ }^{*}$ I. M. Weinstein, R. H. Ettinger, ${ }^{*}$ and R. B. Capps **
}

\section{SUMMAR Y}

Patients with chronic liver disease are found frequently to have such hematologic disorders as anemia, leucopenia, thrombopenia, and reticulocytosis (1-5). Anemia has been reported to occur in 40 to 90 per cent of patients with cirrhosis of the liver $(5-7)$. The mechanism of the anemia has been the subject of numerous investigations $(3,5-9)$. Watson $(10)$ and others $(11-13)$ have found evidence of increased erythrocyte destruction. Other investigators have observed macrocytosis and have implicated a deficiency in the hematologic principles of Castle, but there is strong evidence that the macrocytic anemia of liver disease is independent of these principles (14).

Studies of the bone marrow of patients with cirrhosis usually reveal a slight to moderate increase in the number of erythroid elements, which may be a reflection of the increased destruction of red cells in the peripheral circulation $(15,16)$.

We have observed leucopenia, thrombopenia, and splenomegaly, fairly common findings in chronic liver disease, in several patients who had cirrhosis of the liver and hemolytic anemia. Two of these patients responded well to splenectomy. It thus seemed likely that a hemolytic process caused by a secondary hypersplenism was more common than had been thought previously.

Measurement of red cell survival time is a direct and accurate means of studying the hemolytic process. Although survival may be determined by several methods, the technique of tagging the cells with radioactive sodium chromate was selected because of its simplicity and adaptability $(17-19)$.

Nineteen patients with various types of liver disease were the subjects in this investigation. Fifteen had cirrhosis of the liver. Of these, 9 cases could be classified as "alcoholic" or "Laennec's" cirrhosis; l patient had hepatitis following yellow fever

* Presented at the Meeting of the Association of American Physicians, Atlantic City, May 4, 1954. The complete text will be submitted for publication in the American Journal of Medicine.

This investigation was conducted under the sponsorship of the Commission on Liver Disease, Armed Forces Epidemiological Board, and was supported in part by the Office of the Surgeon General, United States Army.

* From the Department of Medicine, Northwestern University Medical School and the Liver Research Laboratory, St. Luke's Hospital, Chicago, Illinois. 
vaccine and arsenic therapy; 4 had a history of probably antecedent hepatitis ( 1 of these had also had arsenic therapy); and 1 had xanthomatous biliary cirrhosis. There were 2 cases of chronic hepatitis. Une patient had a chronic biliary obstruction secondary to cholecystectomy, and another had a typical acute viral hepatitis and was studied during the acute phase of his illness.

Liver biopsies were obtained in all cases except from those with bleeding tendencies; the patient with acute hepatitis and 3 of the patients with cirrhosis. Diagnoses for these patients were based upon typical laboratory and clinical findings.

Each.subject's blood was labeled with $\mathrm{Na}_{2} \mathrm{Cr}^{5 \mathrm{l}} 0_{4}$ according to the method described previously (18). Standard hematologic procedures were used to measure the hematocrit, hemoglobin, white cell, and platelet values. Females with hematocrit values below 37 and males, below 40 were considered to be anemic. A diagnosis of thrombopenia was made when the platelet count was below 150,000 per cu mm by direct count or below 500,000 per cu mm using a modification of Dameschek's indirect method $^{(20)}$. Reticulocytes were counted on blood films stained with brilliant cresyl blue. The direct Coombs test was performed on fresh blood at room temperature using potent absorbed antisera. Watson's quantitative method ${ }^{(21)}$ was used to determine the excretion of fecal urobilinogen. All stool specimens were checked routinely for occult blood, and the tracer study was not done if they were persistentiy positive.

Bone marrow from 18 of the patients was studied by means of the supra-vital staining technique.

Serial liver function tests, which were performed on all of the patients, included the quantitative Van den bergh reaction, bromsulphthalein test, cephalin cholesterol flocculation, thymol flocculation and turbidity, zinc sulfate turbidity, ammonium sulfate turbidity, alkaline phosphatase, prothrombin time, and serum cholinesterase.

Ten normal adults without symptoms of hematologic or hepatic disorders served as the control group. Their red cell apparent half-survival time was found to be $33^{\prime} \pm$ 3.2 days.

The experimental results indicate that increased hemolysis is a rather frequent occurrence in patients with chronic liver disease. Eight patients (42 per cent) had abnormal apparent half-survival time (below 26 days--2 standard deviations from normal) of the red cells, and all of the 8 had cirrhosis of the liver (Table 1). Four other patients with cirrhosis had apparent half-survival times of 26 days, and it is quite conceivable that they also had a slight degree of hemolysis since the bone marrow in 3 of them revealed erythrocytic hyperplasia.

Only three of the patients with abnormal half-survival times had anemia that could be detected by serial hematocrit determinations (Table 2). All of the patients with abnormal red cell survival curves, with one exception, had a moderate or marked erythroid hyperplasia of the bone marrow. It thus appears that the bone marrow in these cases was able to maintain a normal cell volume in the face of red cell destruction of this magnitude. 


\section{4}

Table 1

Clinical and laboratory data on patients studied

\begin{tabular}{|c|c|c|c|c|c|c|c|c|c|c|c|c|c|}
\hline Name & Age & Sex & Diagnosis & $\begin{array}{c}\text { Apparent } \\
\text { Red cell } \\
1 / 2 \text { Life } \\
\text { (days) }\end{array}$ & $\begin{array}{c}\text { Hemat- } \\
\text { ocrit } \\
(\%)\end{array}$ & $\begin{array}{c}\text { Reticu- } \\
\text { locyte } \\
\text { Count } \\
(\%)\end{array}$ & $\begin{array}{c}\text { Fecal } \\
\text { urobili- } \\
\text { nogen } \\
(\mathrm{mg} / 24 \mathrm{hr})\end{array}$ & $\begin{array}{c}\text { Coombs } \\
\text { tes.t }\end{array}$ & $\mathrm{WBC}$ & $\begin{array}{l}\text { Throm- } \\
\text { bopenia }\end{array}$ & $\begin{array}{l}\text { Bone } \\
\text { marrow }\end{array}$ & $\begin{array}{c}\text { VDB } \\
1 / \text { Total } \\
\text { (mg/100 } \\
\text { ml) }\end{array}$ & $\begin{array}{l}\text { Spleno- } \\
\text { megaly }\end{array}$ \\
\hline
\end{tabular}

Patients with "abnormal" apparent red cell $1 / 21$ ife

\begin{tabular}{|c|c|c|c|}
\hline E.F. & 60 & $\mathbf{M}$ & Cirrhosis \\
\hline J.C. & 52 & $\mathbf{M}$ & Cirrhosis \\
\hline B.M. & 31 & $M$ & Cirrhosis \\
\hline v.S. & 52 & $\mathbf{F}$ & Cirrhosis \\
\hline J.S. & 39 & $\mathbf{M}$ & Cirrhosis \\
\hline R.P. & 66 & $\mathbf{M}$ & Cirrhosis \\
\hline S.I. & 57 & $\mathbf{M}$ & Cirrhosis \\
\hline J.D. & 46 & $\mathbf{M}$ & Cirrhoșis \\
\hline
\end{tabular}

\begin{tabular}{|c|c|c|c|c|c|c|c|c|}
\hline 15 & 24.0 & 5.8 & 546 & 0 & 4200 & + & ++++ & $.2 / .4$ \\
\hline 15 & 44.6 & 2.3 & 277.2 & & 3500 & + & +++ & $.3 / 1.9$ \\
\hline 20 & 39.0 & 4.1 & 128 & 0 & 4250 & + & ++++ & $3.5 / 7.2$ \\
\hline 21 & 45.0 & 1.5 & 70.2 & 0 & 7250 & + & + & $.2 / .5$ \\
\hline 23 & 47.0 & 0.5 & 80.7 & 0 & 1.0200 & 0 & ++ & $.16 / .6$ \\
\hline 23 & 42.0 & 1.4 & & + & 3150. & + & $++t$ & $.2 / 1.0$ \\
\hline 24 & 43.0 & 0.6 & & & 4600 & + & ++ & $.1 / .7$ \\
\hline 25 & 39.0 & 2.9 & 119.4 & 0 & 7100 & + & $+++t$ & $.5 / 1.7$ \\
\hline
\end{tabular}

Patients with "normal" apparent red cell $1 / 2$ life

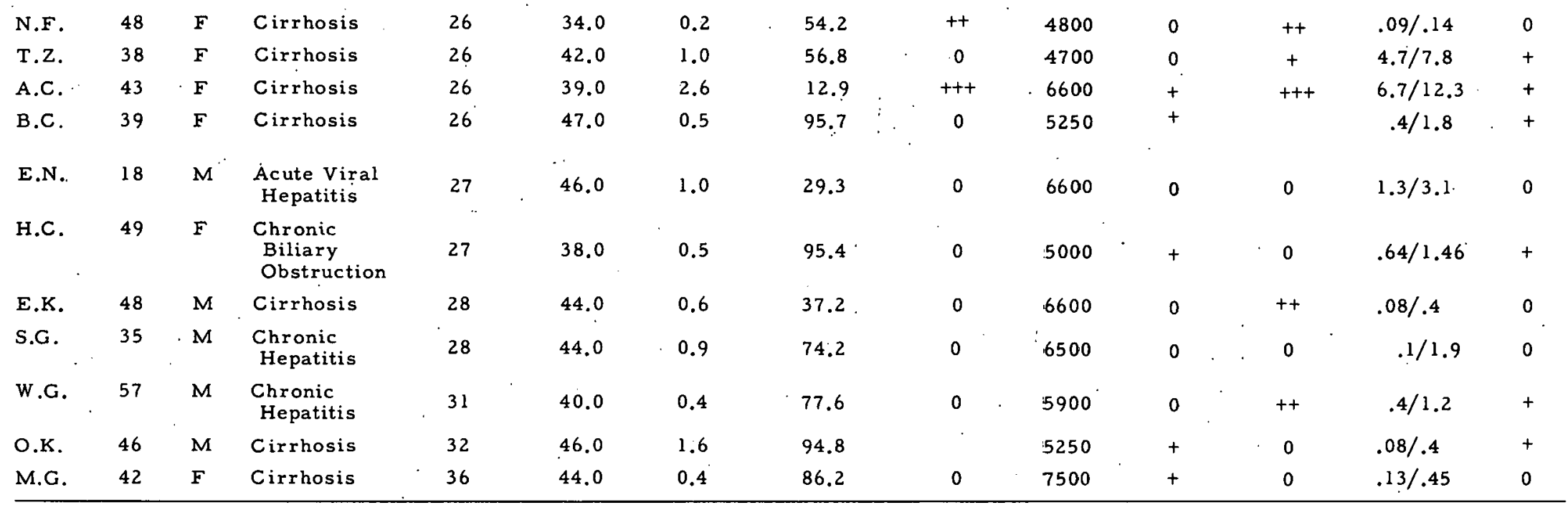


Table 2

Comparison of data from patients with "abnormal" versus "normal" apparent red cell half-lifes.

$$
\text { Number of Cases with... }
$$

\begin{tabular}{|c|c|c|c|c|c|c|}
\hline $\begin{array}{l}\text { No. of } \\
\text { cases }\end{array}$ & Anemia & $\begin{array}{l}\text { Leuco- } \\
\text { penia }\end{array}$ & $\begin{array}{c}\text { Thrombo- } \\
\text { penia }\end{array}$ & $\begin{array}{l}\text { Reticu- } \\
\text { locyte } \\
\text { Counts } \\
1.5 \%\end{array}$ & $\begin{array}{c}\text { Abnormal } \\
\text { bone } \\
\text { marrow }\end{array}$ & $\begin{array}{l}\text { Spleno- } \\
\text { megaly }\end{array}$ \\
\hline
\end{tabular}

\begin{tabular}{lrllllll}
\hline Abnormal & 8 & 3 & 5 & 7 & 4 & 8 & 6 \\
Normal & 11 & 1 & 2 & 5 & 2 & 5 & 6 \\
\hline
\end{tabular}

Neither the reticulocyte response nor the excretion of fecal urobilignogen was found to provide a means of detecting mild and moderate degrees of hemolysis in patients with liver disease.

The experimental data were subjected to the Chi square test (Table 3 ) to determine the significance of our findings. From the analysis it can be seen that the occurrence of abnormal red cell survival times in cases of cirrhosis is not due to chance alone. This is also true for the occurrence of thrombopenia and hyperplasia in the bone marrow. The incidence of splenomegaly in cirrhotic patients, however, does not differ. from that in other diseases of the liver at a 95 per cent level of confidence.

Table 3

Significance of the association between abnormal values for apparent half-survival time of the red cells, and other factors in the clinical syndrome, as tested hy the C.hi square test.

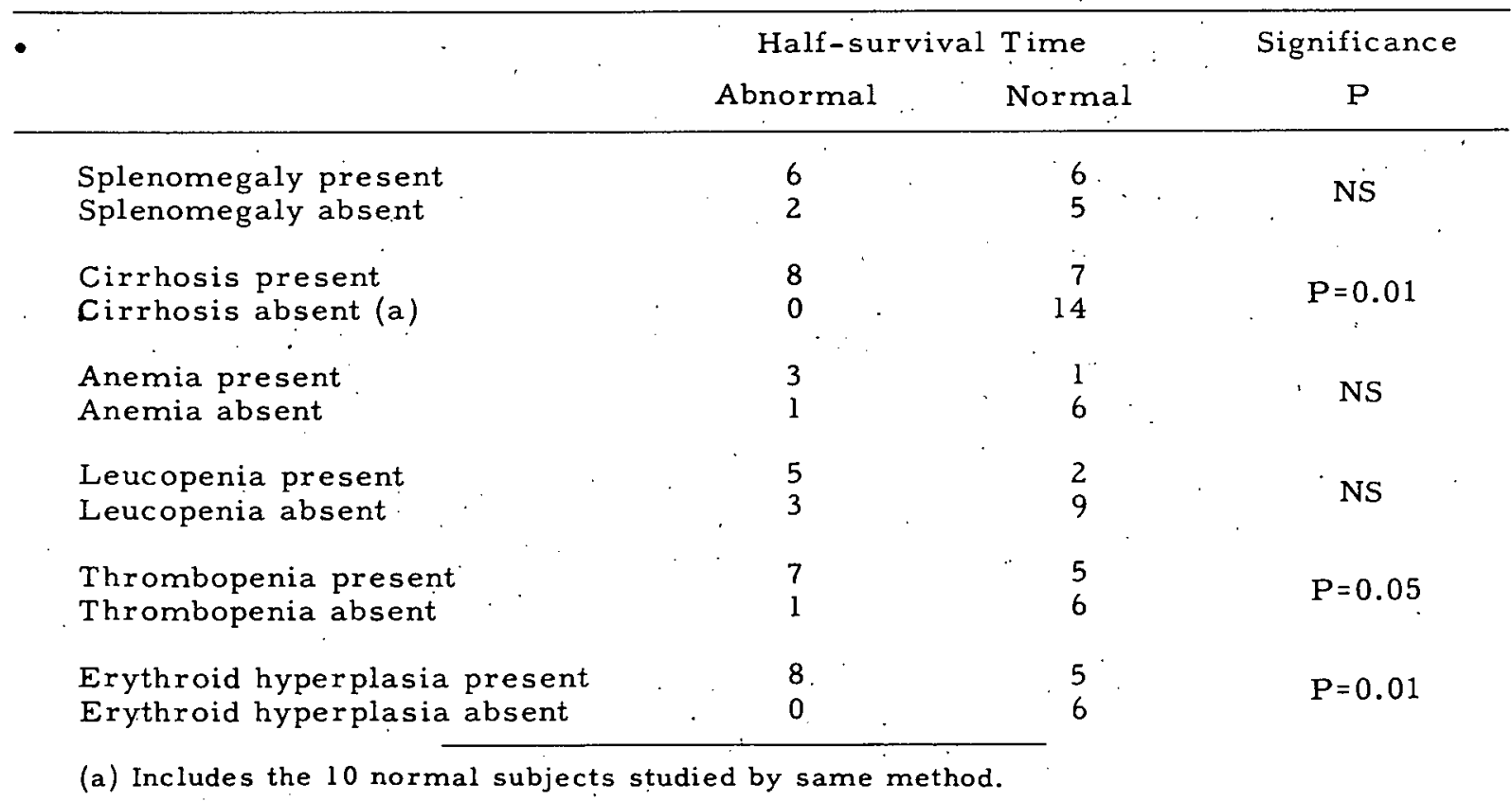


Although we have not attempted to determine the actual cause of the apparent hemolytic prociess, it would seem, from the frequent association with splenomegaly and the lowered white blood cell and platelet counts, that the most satisfactory explanation is hypersplenism secondary to increased portal pressure.

\section{LITERATURE CITED}

1. King, R. B. The blood picture in portal cirrhosis of the liver: A report based on one hundred cases, New England J. Med. 200: 482 (1929).

2. Jordan, F. M. and C. S. McVicar. Anemia in jaundice. I. A clinical study of cases in which jaundice was of the obstructuve or intrahepatic types. Am. J. Med. Sc. 179: 654 (1930).

3. Rosenberg, D. H. and A. Walters. Maçrocytic anemia in liver disease, particularly cirrhosis. Observations on the incidence, course, and reticulocytosis, with a correlated study of the gastric acidity. Am. J. Med. Sc. 192: 86 (1936).

4. Morlock, C. O. and B. E. Hall. Association of cirrhosis, thrombopenia hemorrhagic tendency. Arch. Int. Med. 72: 69 (1943).

5. Gottardo, P. and W. L. Winters. Portal cirrhosis, a correlation of clinical, laboratory, peritoneoscopic and autopsy findings. Am. J. Med. Sc. 204: 204 (1942).

6. Wintrobe, M. M. Relation of disease of the liver to anemia. Type of anemia, response to treatment, and relation of type of anemia to histopathologic changes in liver, spleen and bone marrow. Arch. Int. Med. 57: 289 (1936).

7. Ratnoff, O. D. and A. J. Patek. The natural history of Laennec's cirrhosis of the liver. Medicine 2l: 207 (1942). $115(1935)$

8. Wright, D. O. Macrocytic anemia and hepatic cirrhosis. Am. J. Med. Sc. 189:

9. Davidson, L. S. P. and H. W. Fullerton. Some rare types of macrocytic anemia. Quart. J. Med. 7: 43 (1938).

10. Watson, C. J. Hemolytic jaundice and macrocytic anemia: Certain observations in a series of 35 cases. Ann. Int. Med. 12: 1782 (1939).

11. Farrar; G. E., Jr., W. E. Burnett, and A. J. Steigman. Hemolysinic anemia and hepatic degeneration cured by splenectomy. Am. J. Med. Sc. 200: 164 (1940).

12. Stacey, R. S. Recurrent fatal hemolytic anemia associated with gross. liver damage and splenomegaly. Am. J. Med.Sc. 212: 586 (1946).

13. Hyman, G. A.; and H. Southworth: Hemolytic anemia associated with liver disease. Am. J. Med. Sc. $221: 448$ (1951).

14. Wintrobe, M. M. Hematology, ed. 3, Lea and Febiger, Philadelphia, 1951.

15. Berman, L., A. R. Axelrod, R. N. Horan, S. D. Jacobson, E. A. Sharp, and E. C. Von der Heide. The blood and bone marrow in patients with cirrhosis of the liver. Blood 4: 511 (1949).

16. Jarrold, R., and R. W. Viltner. Hematologic observations in patients with chronic hepatic insufficiency. Sternal bone marrow, morphology in bone marrow plasmacytosis. J. Clin. Investigation 28: 286 (1949).

17. Ebaugh, F.G., Jr., C. P. Emerson, and J. F. Ross. The use of radioactive chromium 51 as an erythrocyte tagging agent for the determination of red cell survival in vivo. J. Clin. Investigation 32: 1260 (1953).

18. Necheles, T. F., I. M. Weinstein, and G. V. LeRoy. Radioactive sodium chromate for the study of survival of red blood cells. I. The effect of radioactive sodium chromate on red cells. J. Lab. Clin. Med. 42: 358 (1953).

19. Weinstein, I. M., T. F. Necheles, and G. V. LeRoy. Radioactive sodium chromate for the study of survival of red blood cells. II. The rate of hemolysis in certain hematologic disorders. J. Lab. Clin. Med. 42: 368 (1953).

20. Dameshek, W. A method for the simultaneous enumeration of blood platelets and reticulocytes. Arch. Int. Med. 50: 579 (1952).

21. Schwartz, S., V. Sborov, and C. J. Watson. Studies of urobilinogen. IV. The quantitative determination of urobilinogen by means of the Evelyn photoelectric colorimeter. Am. J. Clin. Path. 14: 598 (1944). 


\section{RADIOACTIVE SODIUM CHROMATE FOR THE STUDY OF SURVIVAL OF RED BLOOID CELLS}

\section{THE ABNORMAL HEMOGLOBIN SYNDROMES ${ }^{*}$}

By

I. M. Weinstein, C. L. Spurling, H. Klein, and T.F. Necheles

\section{SUMMARY}

Chromium 51 (as $\mathrm{Na}_{2} \mathrm{Cr}^{5 \mathrm{l}_{0}} \mathrm{O}_{4}$ ) has been used to study the survival time of erythrocytes in normal human subjects and in those with hematologic disorders $(1,2)$. A survey of the literature indicates that the investigations outlined in this summary. are the first in which the $\mathrm{Cr}^{51}$-labeling technique has been used to study red cell. survival in a group of patients with abnormal hemoglobin syndromes.

The finding that hemoglobin from patients with sickle cell anemia differs electrophoretically from hemoglobin from normal human beings ${ }^{(3)}$ stimulated new interest in hemolytic syndromes associated with abnormal hemoglobins. Singer and his co-workers $(4,5)$, by quantitating fetal hemoglobin, reported elevated values in patients with sickle cell anemia and in those with severe cases of thalassemia. Hemoglobin C, another abnormal type, was found in American Negroes by Itano and Neel ${ }^{(6)}$ and independently by Kaplan, Zuelzer, and Neel ${ }^{(7)}$. Hemoglobin D, which has the electrophoretic properties of sickle cell hemoglobin but which does not produce sickling, was discovered in one Negro family ${ }^{(8)}$.

For our studies, $100 \mathrm{ml}$ of blood was withdrawn from each patient, labeled with $200 \mu \mathrm{c}$ of $\mathrm{Cr}^{5 \mathrm{l}}$, according to the technique described previously ${ }^{(1,2)}$, and re-injected. All of the patients who were studied were Negro.

The one-half survival time of $\mathrm{Cr}^{51}$-labeled erythrocytes in the normal human being is calculated to be $33.1 \pm 3.2$ days (Figure 1 ).

Red cell, hemoglobin, and hematocrit values were determined by standard hematologic techniques. Reticulocytes were counted after staining with brilliant cresyl blue. Sickling was tested by the sodium metabisulfite method. Electrophoretic mobility of the hemoglobin solutions was measured by the filter paper technique ${ }^{(9)}$

* The complete text appears in Blood (in press). 


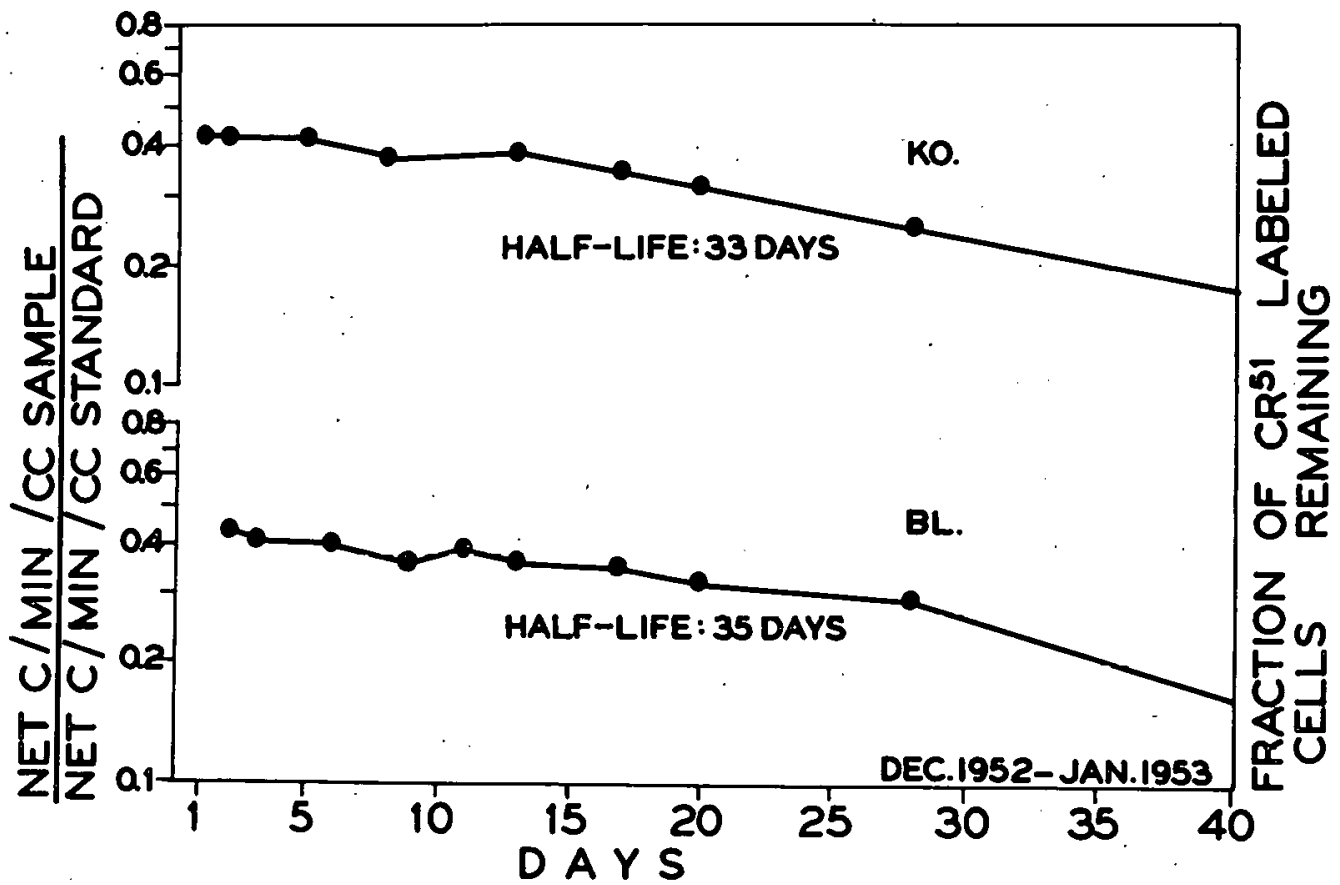

Figure 1. Red cell survival curvcs in two normal subjects.

Singer's method ${ }^{(4)}$ was used to determine alkali-resistant hemoglobin. Osmotic fragility was tested on freshly-drawn venous blood, and mechanical fragility was measured by the method of Shen, Castle, and Fleming ${ }^{(10)}$. The excretion of fecal urobilinogen was determined on pooled 3-day collections of feces by the semi-quantitative method of Watson (11), and the results are expressed in Ehrlich units.

Sickle cell anemia: Hematologic data for 4 patients with sickle cell anemia are given in. Table 1 , and the erythrocyte survival curves, in Figure 2.

Table 1

Hematalogic data from sickle cell anemia patients

\begin{tabular}{lcccc}
\hline & T.P. & M.W. & G.L. & L.A. \\
& $24, \dot{q}$ & $39, \dot{q}$ & $32, \dot{q}$ & $31,+$ \\
\hline Hemoglobin $(\mathrm{g} / 100 \mathrm{cc})$ & 8.3 & 5.5 & 7.7 & 6.2 \\
Red blood count $(\mathrm{x} 106)$ & 2.72 & 1.48 & 1.98 & 1.70 \\
White blood count & 7700 & 13,100 & 12,000 & 11,600 \\
Reticulocytes $(\%)$ & 9.0 & 21.0 & 16.6 & 11.5 \\
Hematocrit & - & 16 & - & 17 \\
Sickle preparation & + & + & + & + \\
Alkali resistant Hgb $(\%)$ & 4.5 & 2.6 & 9.7 & 7.0 \\
Electrophoretic pattern & $\mathrm{S}$ & $\mathrm{S}$ & $\mathrm{S}$ & $\mathrm{S}$ \\
\hline
\end{tabular}




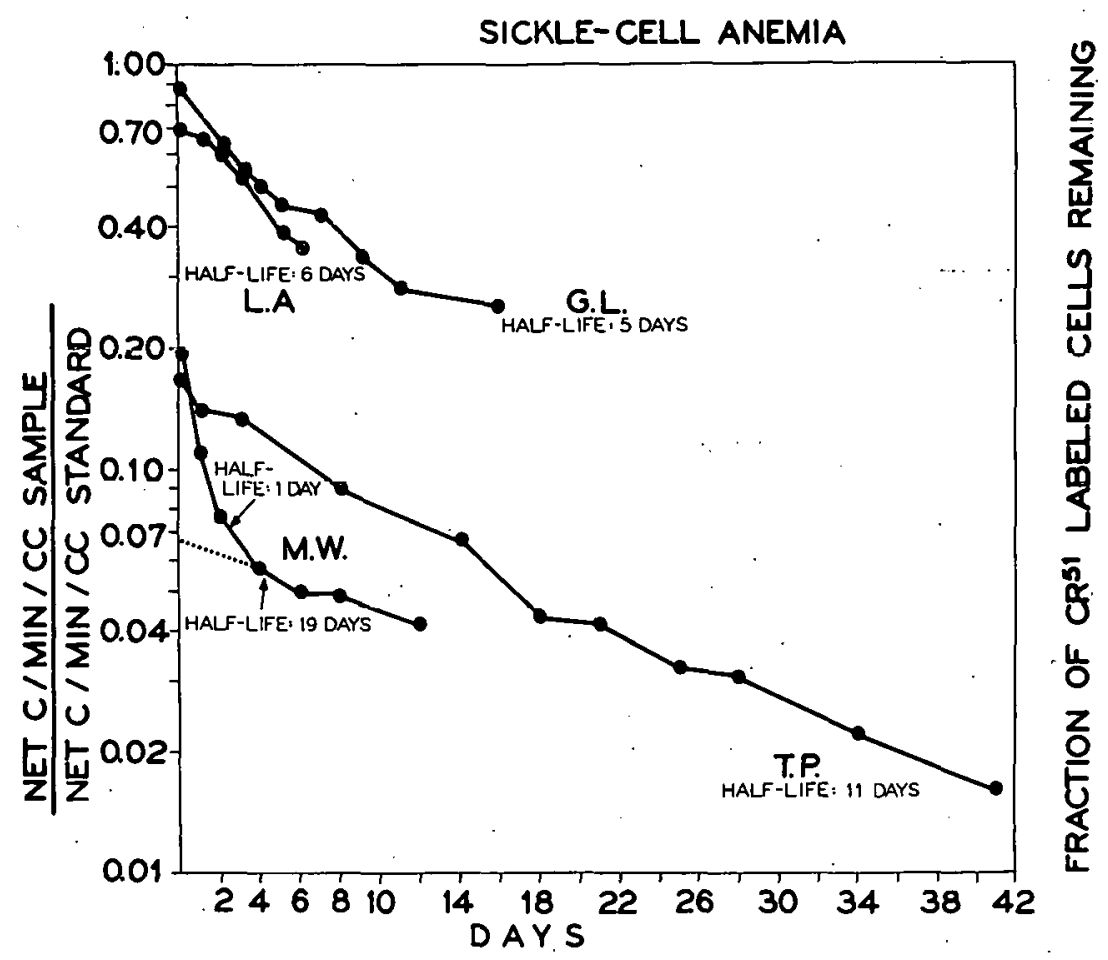

Figure 2. Red cell survival curves for four patients with sickle cell anemia.

The extent of red cell destruction was found to be of the same order of magnitude as that determined by Ashby's differential agglutination technique.. The erythrocyte survival curve for one of the patients (M.W.) has two distinct components. These components have appeared in the data from other patients who were studied by the Ashby technique, but their significance is not completely understood. An uneven distribution of $S$ and $F$ hemoglobin in the erythrocytes has been demonstrated ${ }^{(12)}$ and may, in part, account for this phenomenon. However, because there is no correlation between the amount of fetal hemoglobin and the severity of the disease and because the data from some patients give a single-component curve, other factors must be contributory. Singer has postulated that stromal factors play a role, and Eadie and Brown ${ }^{(13)}$ have shown that the continuing and accelerated destruction and senscence of these cells may account for the two components.

Sickle cell trait: Hematologic data and red cell survival for a father and son with sickle cell trait are given in Table 2 and Figure 3.

Our findings on the survival time of erythrocytes from patients with sickle cell trait confirm those of other investigators $(14,15)$ who found no deviation from normal values.

Hemoglobin C disease: The survival time of erythrocytes from a patient with homozygous hemoglobin $\mathrm{C}$ disease is given in Figure 4. 
Table 2

Hematologic data from sickle cell trait patients.

\begin{tabular}{l|c|c}
\hline & $\begin{array}{c}\text { E.R. } \\
38, q\end{array}$ & $\begin{array}{c}\text { R.R. } \\
15, q\end{array}$ \\
\hline Hemoglobin (g/100 cc) & 14.6 & 13.4 \\
Red blood count (x 106) & 4.63 & 4.39 \\
White blood count & 7400 & 6500 \\
Reticulocytes (\%) & 0.9 & 1.4 \\
Sickle cell preparation & + & + \\
Alkali resistant Hgb (\%) & 0.71 & 1.0 \\
Electrophoretic pattern & $\mathrm{A}+\mathrm{S}$ & $\mathrm{A}+\mathrm{S}$ \\
\hline
\end{tabular}

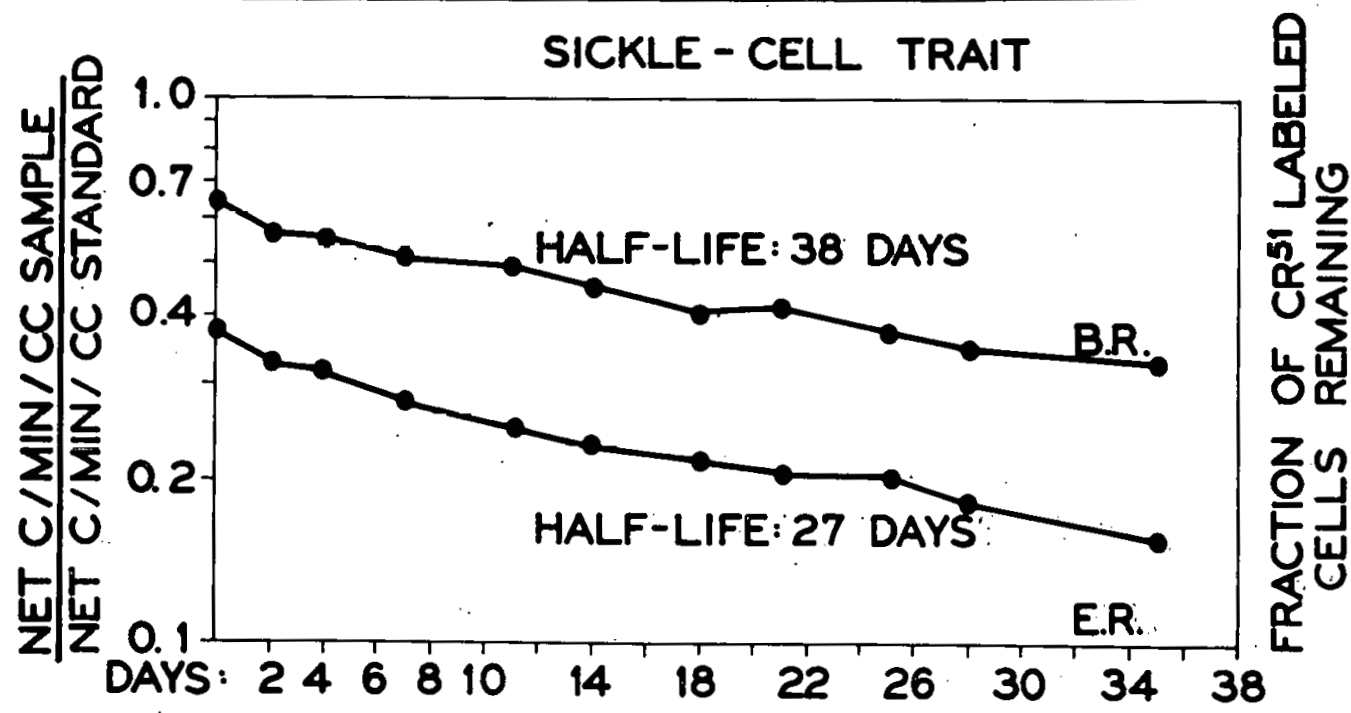

Figure 3. Red cell survival curves for two subjects with sickle cell trait.

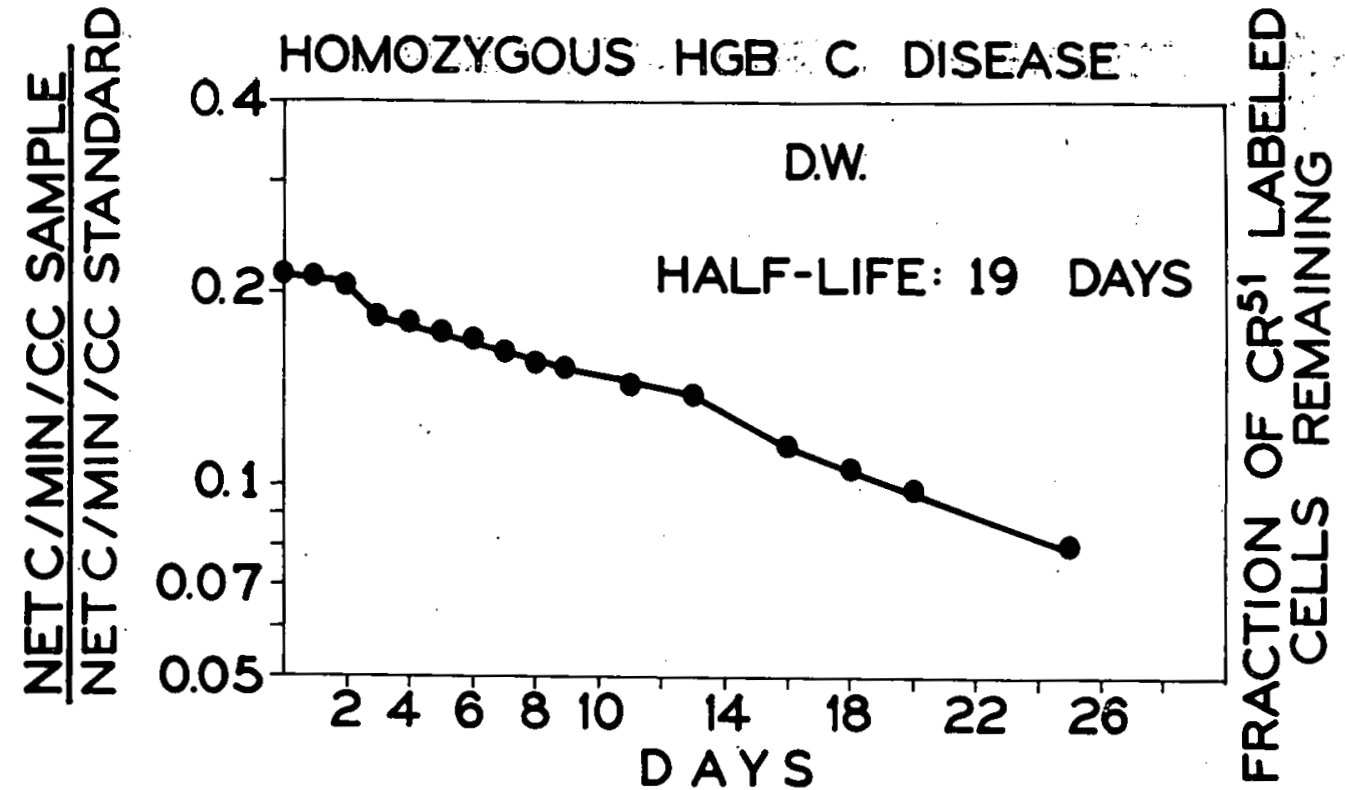

Figure 4. Red cell survival cyrve for a patient with hemoglobin $C$ disease. 
The patient presented a clinical syndrome of a compensated hemolytic disease, splenomegaly, and an increased number of target cells with no previous family history of anemia. The excessive red cell destruction was found to be similar to that described by Spaet, who used the Ashby technique.

Hemoglobin $\mathrm{C}$ trait: The hematologic data for two subjects with hemoglobin C trait are given in Table 3. Figure 5 shows the erythrocyte survival curves.

Table 3

Hematologic data from hemoglobin $\mathrm{C}$ trait patients.

\begin{tabular}{l|c|c}
\hline \multicolumn{1}{c|}{} & B.R. & E.C. \\
& 38, & 55, \\
\hline Hemoglobin $(\mathrm{g} / 100 \mathrm{cc})$ & 15.0 & 14.7 \\
Red blood count $\left(\mathrm{x} 10^{6}\right)$ & 4.87 & 4.68 \\
White blood count & 6650 & 4500 \\
Reticulocytes $(\%)$ & 0.5 & 1.9 \\
Target cells (\%) & 25 & 55 \\
Sickle preparation & Neg. & Neg. \\
Alkali resistant Hgb (\%) & 0.85 & 0.75 \\
Electrophoretic pattern & A C & A C \\
\hline
\end{tabular}
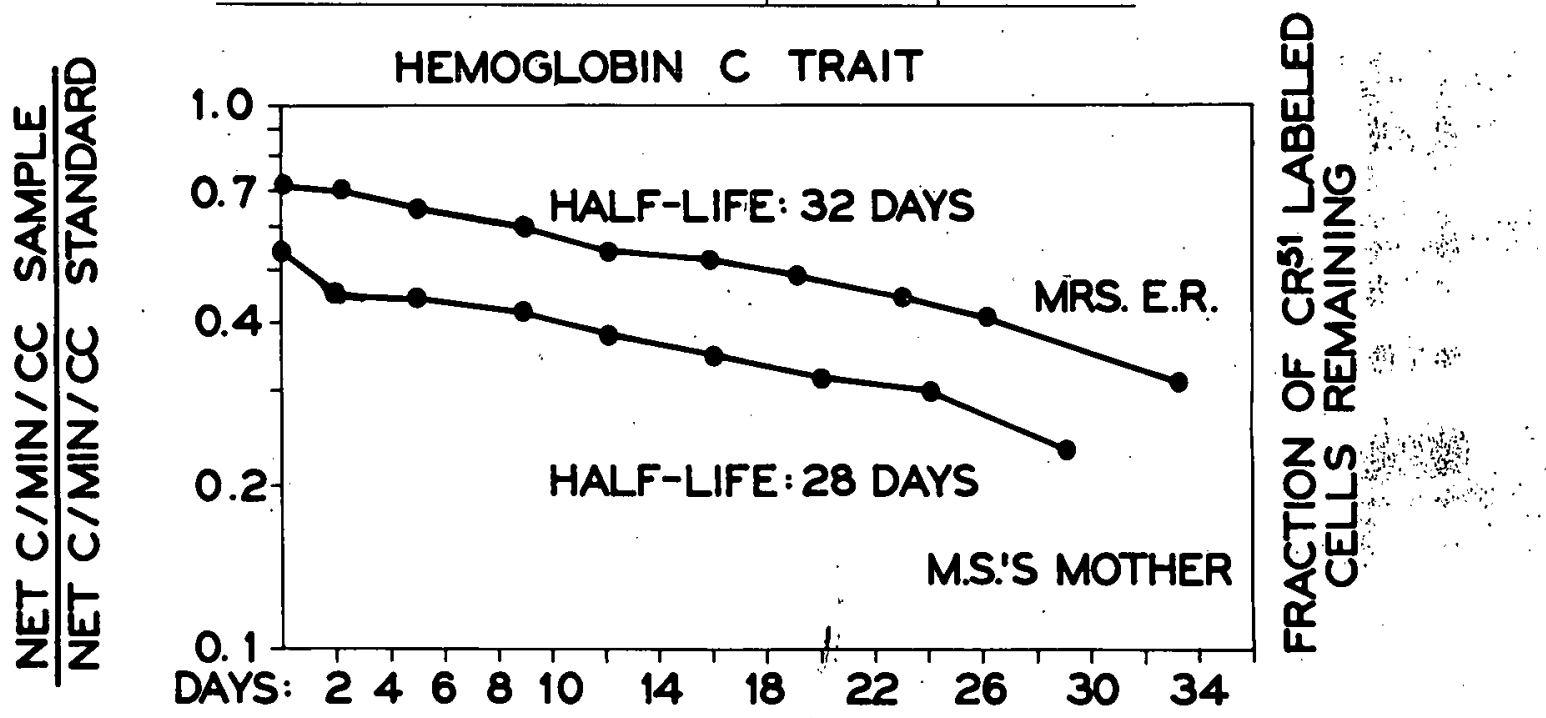

Figure 5. Red cell survival curves for two subjects with hemoglobin C trait.

An excessive number of target cells appeared to be the only abnormality that was attributable to the hemoglobin $\mathrm{C}$ trait.

Sickle cell anemia - Hemoglobin C: Electrophoretic analysis revealed the presence of both $C$ and $S$ hemoglobin in a patient with only a mild hemolytic process. The erythrocyte survival curve (Figure 6), however, was abnormal and similar to those for patients with hemoglobin $C$ disease. It should be emphasized that $C$ and $S$ 


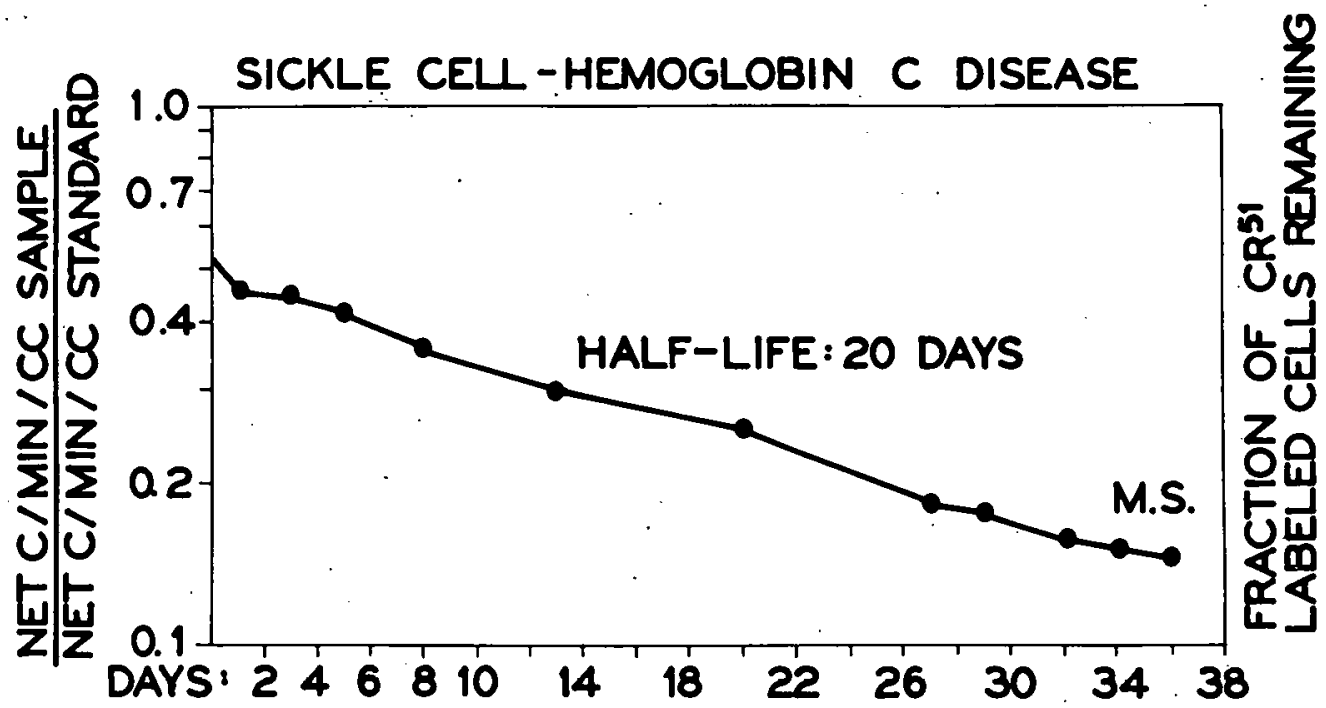

Figure 6 . Red cell șurvival curvefor a patient with sickle cell - hemoglobin $C$ disease.

hemoglobin should be suspected in Negroes who have sickling with only mild hemolytic manifestations. In these patients, splenomegaly persists into adulthood and the number of target cells is elevated.

These studies reveal that the survival of erythrocytes in patients with sickle cell anemia is decreased markedly. The life span of these cells was also found to be shortened in one patient with hemoglobin $\mathrm{C}$ disease and in another with sickle cellhemoglobin $C$ disease with compensated hemolysis.

The data obtained by means of the $\mathrm{Cr}^{51}$ technique are in agreement with those by the Ashby technique. The method, which has been found to be simple, adaptable, and reliable, reveals that chromate attaches to both normal and abnormal hemoglobin in the same manner and it may be used to measure the survival of erythrocytes that contain abnormal types of hemoglobin.

\section{LITERATURE CITED}

1. Necheles, T. F., I. M. Weinstein, and G. V. LeRoy. Radioactive sodium chromate for the study of survival of red blood cells. I. The effect of radioactive sodium chromate on red cells. J. Lab. Clin. Med. 42: 358 (1953).

2. Weinstein, I. M. and G. V. LeRoy. Radioactive sodium chromate for the study of survival of red blood cells. II. The rate of hemolysis in certain hematologic disorders. J. Lab. Clin. Med. 42: 368 (1953).

3. Pauling, L., H. A. Itano, S. J. Singer, and I. C. Wells. Sickle cell anemia, a molecular disease. Science 110: 543 (1949).

4. Singer., K. A., I. Chernoff, and L. Singer. Studies on abnormal hemoglobins. I. Their demonstration in sickle cell anemia and other hematologic disorders by means of alkali denaturation. Blood 6: 413 (1951).

5. Singer, K. A., I. Chernoff, and L. Singer. Studies on abnormal hemoglobins. Their identification by means of the method of fractional denaturation. Blood 6: 429 (1951). 
6. Itano, H. A. and J. V. Neel. A new inherited abnormality of human hemoglobin. Proc. Nat. Acad. Sci. 36: 613 (1950).

7. Kaplan, E., W. W. Zuelzer and J. V. Neel. A new inherited abnormality of hemoglobin and its interaction witli sicklc cell hemoglobin. Blood 6: 1240 (1951).

8. Itano, H. A. A third abnormal hemoglobin associated with hereditary hemolytic anemia. Proc. Nat. Acad. Sci. 37: 775. (1951).

9. Spaet, T. H. Identification of abrormal hemoglobins by means of paper electrophoresis. J. Lab. Clin. Med, 41: 161 (1953).

10. Shen, S. C., W. B. Castle, and E. M. Fleming. Experimental and clinical observations on increased mechanical fragility of erythrocytes. Science 100 : 387 (1944).

11. Watson, C. J., S. Schwartz, V. Sborov, and E. Bertie. Studies of urobilinogen. V. A simple method for the quantitative recording of the Ehrlich reactions as carried out with urine and feces. Am. J. Clin. Path. 14: 605 (1944).

12. Singer, K. and B. Fisher. Studies on abnormal hemoglobins. V. The distribution of type $S$ (sickle cell) hemoglobin and type F (alkali resistant) hemoglobin within the red cell population in sickle cell anemia. Blood 7: 1216 (1952).

13. Eadie, G. S. and I. W. Brown, Jr. Analytical review: Red blood cell survival studies. Blood 8: 1110 (1953).

14. Singer, K., S. Robin, J. C. King, and R. N. Jefferson. The life span of the sickle cell and the pathogenesis of sickle cell anemia. J. Lab. Clin. Med. 33: 975 (1948).

15. Callender, S. T. E., J. F. Nickel, C. V. Moore and E. O. Powell. Sickle cell disease studied by measuring the survival of transfused red blood cells. J. Lab. Clin. Med. 34: 90 (1949). 
THE EFFECT OF GROWTH IN A NONIRRADIATED HOST UPON THE RECOVERY OF IRRADIATED BACTERIA

\author{
By \\ E. Beutler, M. J. Robson, and L. O. Jacobson
}

INTRODUCTION

Evidence for the existence of a humoral factor in the recovery of a mammal from the effects of ionizing radiations has been reviewed (1), and attempts to demonstrate such activity in various cell-free extracts have been unsuccessful (1). One possible reason for this failure may be the instability of the active fraction or fractions, so that continuous replenishment is necessary. Such replenishment may be achieved by growing irradiated cells in the tissue fluids of a nonirradiated animal. Technical difficulties that must be overcome to treat irradiated tissue cells in this manner are quite obvious, but bacterial cells may be used with comparative ease. Although there is no evidencethat the mechanisms causing radiation damage are similar in bacteria and. mammalian cells, this indirect approach appeared reasonable.

\title{
MATERIALS AND METHODS
}

Cultures of type XXXI Diplococcus pneumoniae: and of Escherichia coli. ${ }^{*}$. were " employed. Stock cultures were stored in a refrigerator on blood plates. The pneumococcus was passed periodically through mice to sustain its virulence.

CF No. 1 mice, aged 10 to 12 weeks, and embryonated hen eggs, aged 10 days, served as the hosts.

All $X$ radiation was administered with a G.E. maxitron unit. Bacterial cultures, which had been allowed to grow overnight at $37^{\circ} \mathrm{C}$, were irradiated in tryptocase soy broth at ice water temperature with $250-\mathrm{kvp} X$ rays at $30 \mathrm{ma}$ with $0.25 \mathrm{~mm}$ of $\mathrm{Al}$ filtration. Two exposure levels were used for the experiments with $D$. pneumoniae: 25,000 and $35,000 \mathrm{r}$. Cultures of E. coli received $30,000 \mathrm{r}$, and the embryonated eggs were exposed to $1000 \mathrm{r}$. The mice, which were anesthetized with Nembutal ${ }^{R}$ during irradiation, were subjected to 500 or $1200 \mathrm{r}$.

*Isolated from patients by Miss Dorcas Fasan, Department of Pediatrics, The University of Chicago.

* Baltimore Biological Laboratory, Baltimore, Maryland. 
The counts that were made on E. coli represent the number of colonies in tryptocase soy pour plates made from appropriate dilutions.

\section{EXPERIMENTAL AND RESULTS}

Two experiments were carried out to determine whether the pathogenicity of irradiated bacteria could be restored by inoculation into normal mice.

Irradiated and nonirradiated mice were inoculated with irradiated or nonir-

- radiated pneumococcus cultures. The death rate was recorded at the end of 3 days, a time at which mortality induced by $1200 \mathrm{r}$ is less than 10 per cent and by $500 \mathrm{r}$ is neg-

- ligible (2). Hence, deaths at this time may be regarded as being due largely to injection. tion. The results of these experiments are given in Table 1 .

Table 1

Mortality of irradiated and nonirradiated mice inoculated. with irradiated and nonir radiated penumococci.

\begin{tabular}{l|c|c|c}
\hline & \multirow{2}{*}{ Exposure } & \multicolumn{2}{|c}{ Pneumococci } \\
& & $0 \mathrm{r}$ & $25,000 \mathbf{r}$ \\
\hline \multirow{2}{*}{ Mice } & $0 \mathbf{r}$ & $10 / 20$ & $5 / 20$ \\
& $1200 \mathbf{r}$ & $9 / 18$ & $10 / 18$ \\
& & $0 \mathbf{r}$ & $35,000 \mathrm{r}$ \\
\hline \multirow{2}{*}{ Mice } & $0 \mathbf{r}$ & $12 / 19$ & $2 / 19$ \\
& $500 \mathbf{r}$ & $13 / 18$ & $10 / 18$ \\
\hline
\end{tabular}

$\therefore \quad \therefore$

$\stackrel{4}{2}$

ititis $\therefore: \cdots$

The growth of irradiated E. coli in the chorio-allantois of embryonated eggs was also studied. Irradiated and nonirradiated eggs were reincubated for 2 hours and then $\ldots$ inoculated with irradiated or nonirradiated cultures. The eggs were rotated manually to insure thorough mixing and colony counts were made on the allantoic fluid 30 minutes and $2-1 / 2$ hours after inoculation. The results of this experiment are given in Table 2 .

\section{DISCUSSION}

Prolonged exposure of irradiated $D$. pneumoniae to the body fluids of nonirradiated mice failed to cause any revival of their pathogenicity. If such revival had occurred, the mortality rate among the nonirradiated mice would have been higher than that of the irradiated mice; tissues of animals exposed to an X - ray LD99 do not stimulate recovery (3). Similarly, the number of viable bacteria in irradiated cultures of E. coli was not increased by incubation in normal embryonated eggs. Neither was there an effect on prolongation of the lag phase, which has been studied more intensively in vitro (4). Although these results fail to support the humoral theory of irradiation 
Table 2

Colony counts on the chorio-allantoic fluid of

ir radiated and nonirradiated embryonated eggs

inoculated with irradiated and nonirradiated $\underline{E}$. coli.

\begin{tabular}{|c|c|c|c|c|c|c|c|c|c|c|c|c|}
\hline $\begin{array}{l}\text { X-ray exposure. } \\
\text { to E. coli }\end{array}$ & \multicolumn{6}{|c|}{$0 \mathbf{r}$} & \multicolumn{6}{|c|}{$30,000 \mathrm{r}$} \\
\hline Size of inoculum & \multicolumn{6}{|c|}{$0.1 \mathrm{cc}$ of $10^{-5}$} & \multicolumn{6}{|c|}{$0.1 \mathrm{cc}$ of $10^{-2}$} \\
\hline $\begin{array}{l}\text { X-ray exposure } \\
\text { to eggs }\end{array}$ & \multicolumn{3}{|c|}{$0 r$} & \multicolumn{3}{|c|}{$1000 r$} & \multicolumn{3}{|c|}{$0 \mathrm{r}$} & \multicolumn{3}{|c|}{$1000 \mathrm{r}$} \\
\hline Egg \# & 1 & 2 & 3 & 1 & $2^{\not}$ & 3 & 1 & $2^{\star ⿱ 亠}$ & 3 & 1 & 2 & 3 \\
\hline $\begin{array}{l}30-\text { minute count } \\
\text { in colonies-1/4 cc } \\
\text { of chorio-allantoic } \\
\text { fluid }\end{array}$ & 118 & 52 & 76 & 58 & 1 & 63 & 59 & 3 & 18 & $\begin{array}{l}63 \\
.\end{array}$ & 39 & 54 \\
\hline $\begin{array}{l}2.5 \text {-hours count } \\
\text { in colonies- }-1 / 4 \mathrm{cc} \\
\text { of chorio-allantoic } \\
\text { fluid }\end{array}$ & 10,200 & 2,100 & 4,500 & 1,600 & 500 & $5, \hat{0} \cup \overline{0}$ & İ 40 & io & 230 & 190 & 130 & 200 \\
\hline
\end{tabular}

* probably not injected chorio-allantoically

recovery, as it may apply to an interspecies relationship, they do not disprove it. They emphasize, however, that the differences between the mechanisms of radiation recovery in bacterial and mammalian cells may be so great that the simplified approach offered by bacteria may have only limited application to studies of factors influencing the recovery of mammals from irradiation damage.

\section{SUMMARY}

Inoculation of irradiated pneumococci into normal mice and of irradiated E. coli into normal embryonated eggs failed to cause demonstrable recovery of the irradiated bacteria.

\section{LITERAT URE CITED}

1. Jacobson, L. O.: Evidence for a humoral factor (or factors) concerned in recovery from radiation injury. A review. Cancer Research, 12: 315 (1952).

2. Jacobson, L. O., E. K. Marks, M. J. Robson, E. Gaston, and R. E. Zirkle. The effect of spleen protection on mortality following X-irradiation. J. Lab. Clin. Med., 34: 1538 (1949).

3. Unpublished data: L. O. Jacobson.

- 4. Beutler, E., M. J. Robson, L. O. Jacobson. Prolongation of the lag phase of irradiated E. coli. Proc. Soc. Exptl. Biol. Med., (in press). 
PROLONGATION OF THE LAG PHASE OF IRRADIATED ESCHERICHIA COLI*

By

E. Beutler, M. J. Robson, and L. U. Jacobson

SUMMARY

We observed that the onset of multiplication of bacteria that survive a heavy exposure to $\mathrm{X}$ radiation is delayed. The observation led to the suggestion that the degree of prolongation might be used to assay materials for a humoral factor that enhances recovery from irradiation.

A single overnight culture of E. coli in tryptocase soy broth was used in each experiment as the source for both irradiated and control bacteria. Cultures that were to be irradiated were placed in Evelyn spectrophotometer tubes that were held in an ice water bath ${ }^{(1)}$. The $X$ rays were generated by a G.E. maxitron machine operating at $250 \mathrm{kvp}$ at $15 \mathrm{ma}$ with $0.25 \mathrm{~mm}$ of Al filtration. Exposure rates varied from 425 to $480 \mathrm{r}$ per min, and the total exposures were 10,000 and $30,000 \mathrm{r}$. Pour plates were made before and at intervals after incubation at $37^{\circ} \mathrm{C} i$

The time of onset of logarithmic growth in the colonies that were exposed to $30,000 \mathrm{r}$ was delayed consistently from $3 / 4$ to $1-1 / 2 \mathrm{hr}$ (Figure 1). A shorter delay. was induced by $10,000 \mathrm{r}$. There was often a slight decrease in the colony counts during the lag phase of the irradiated cultures. However, the logarithmic rate of growth was found to be the same for both the irradiated and control cultures.

Cultures of $\underline{E}$. coli were irradiated and then diluted 100-fold into fresh tryptocase soy broth to test whether the irradiated medium might be responsible for the prolonged lag phase. The data indicate that this is not the case.

Prolongation of the lag phase was increased to $2-1 / 2 \mathrm{hr}$ and the rate of growth in the logarithmic growth phase was considerably reduced when the bacteria were incubated at $24^{\circ} \mathrm{C}$ after irradiation.

Bacteria that were stored at -2 and $7^{\circ} \mathrm{C}$ for several weeks after irradiation had a prolonged lag phase upon reincubation, but storage of nonirradiated control cultures at these temperatures also resulted in some reduction in the initial rate of multiplication.

Various substances were tested to learn whether they might modify the $X$-rayinduced lag phase. These substances were added to the cultures after irradiation but * The complete text appears in Proc. Soc: Exptl. Biol. Med. 85:682 (1954). 


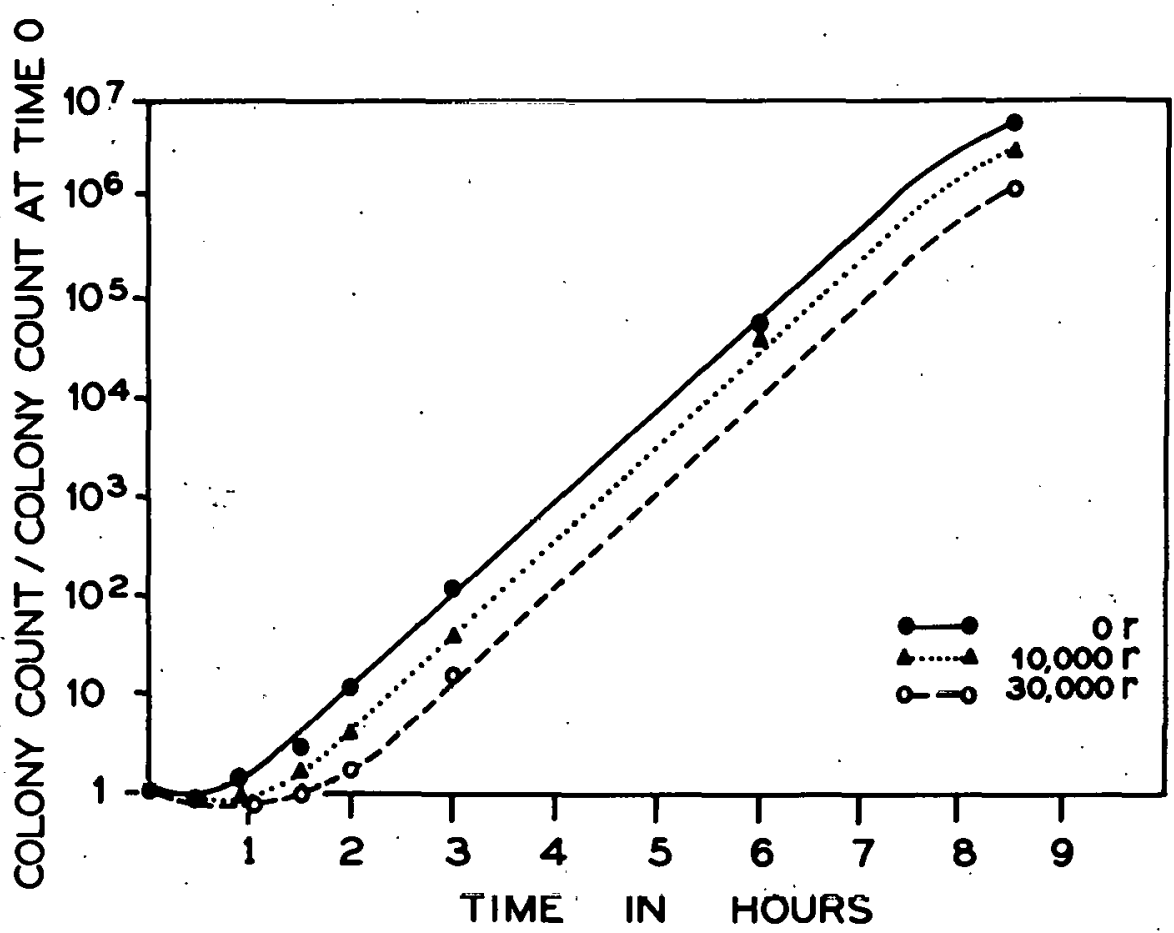

Figure 1. Growth curves of irradiated and nonirradiated cultures of $\mathrm{E}$. coli.

prior to incubation, and growth at the end of $2 \mathrm{hr}$ was chosen as the endpoint. Media containing mouse blood, rabbit serum, cysteine, or the filtrate of actively-growing nonirradiated E. coli were ineffective. The addition of fresh spleen, liver, or kidney mash from mice altered the growth curves in the direction of normal, but these substances also had a stimulating effect on nonirradiated cultures. Spleen or liver mash from mice exposed to $900 \mathrm{r}$ had a less marked effect but did influence growth. The growth of irradiated colonies that were maintained in medium containing activelygrowing nonirradiated bacteria was not altered.

Although spleen and liver mash modified the $\mathrm{X}$-ray-induced prolongation of the lag phase, they also modified the normal lag phase, and an effect of equal magnitude was obtained when mouse kidney mash was used. Since kidney mash has not been found to enhance the recovery of a mammal from irradiation and since liver and spleen mash from irradiated mice also reduced the time of prolongation, it is quite unlikely that the growth-promoting activity that has been observed represents the humoral factor that is the basis for recovery in the mammal.

\section{LITERATURE CITED}

1. Stapleton, G. E., A. Hollaender, and F. L. Martin. Mechanism of lethal and mutagenic action of ionizing radiation on Aspergillus terreus. II. Use of modifying agents and conditions. J. Cell. Comp. Physiol., 39: Supplement, March, 1952 


$$
\frac{I-7 n^{n}}{1-58}
$$

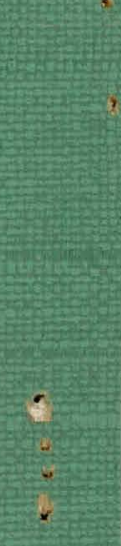

